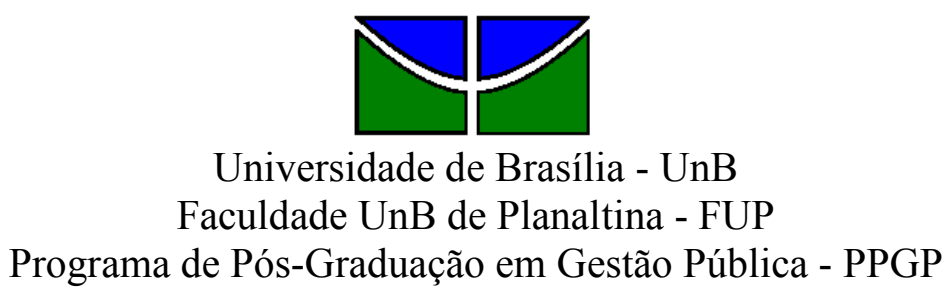

JULIANA VIEIRA SALDANHA

EXEQUIBILIDADE DAS COMPRAS PÚBLICAS SUSTENTÁVEIS EM UMA INSTITUIÇÃO DE ENSINO DA REGIÃO NORTE DO BRASIL

Brasília - DF

Maio 2016 
Dissertação apresentada ao Programa de PósGraduação em Gestão Pública, Mestrado Profissional em Gestão Pública, da Faculdade UnB de Planaltina, da Universidade de Brasília como requisito parcial à obtenção do título de Mestre em Gestão Pública.

Professora Orientadora: Dra. Lucijane Monteiro de Abreu

Brasília - DF 
$\operatorname{VSA} 162$

Vieira Saldanha, Juliana

Exequibilidade das Compras Públicas Sustentáveis em uma Instituição de Ensino da Região Norte do

Brasil / Juliana Vieira Saldanha; orientador Lucijane Monteiro de Abreu. -- Brasília, 2016. $180 \mathrm{p}$.

Dissertação (Mestrado - Mestrado Profissional em Gestão Pública) -- Universidade de Brasília, 2016.

1. Políticas Públicas. 2 .

Desenvolvimento Sustentável. 3. Compras

Públicas Sustentáveis. I. Monteiro de

Abreu, Lucijane, orient. II. Título. 


\title{
EXEQUIBILIDADE DAS COMPRAS PÚBLICAS SUSTENTÁVEIS EM UMA INSTITUIÇÃO DE ENSINO DA REGIÃO NORTE DO BRASIL
}

\author{
JULIANA VIEIRA SALDANHA
}

Composição da Banca Examinadora:

Dra. Lucijane Monteiro de Abreu

Professora-Orientadora

Dr. Alexandre Nascimento de Almeida, Professor-Examinador Interno
Dr. Weeberb João Réquia Júnior

Professor-Examinador Externo

Dr. Mário Lúcio de Ávila

Professor - Examinador Interno Suplente

Brasília, 23 de maio de 2016. 
Aos amores da minha vida, minha família que pela cumplicidade e demonstração de confiança me proporcionam condições de fortalecimento a cada dia. E aos servidores públicos que desempenham seu papel com o compromisso de proporcionar um país melhor para se viver na coletividade. 


\section{AGRADECIMENTOS}

Quando eu lia os agradecimentos nos trabalhos de conclusões, muitas vezes imaginava que se tratava de formalidades, porém quando pude participar ativamente do que é ter o conforto materializado pelo apoio, percebi que é um momento de verdadeira gratidão.

Diante de tantos obstáculos vividos nesse período, é praticamente impossível passar pelas provações sem a ajuda de alguém. Por isso, antes de agradecer, eu peço também desculpas pelo trabalho dado a vocês. A Deus pelos momentos de lamentações, orações e solicitações incansáveis de sabedoria de como conduzir e o que priorizar diante de responsabilidades que, no meu entender não poderiam falhar. Obrigada pela estrutura, pelas bênçãos derramadas e pelos momentos de introspecção em que pude ter intimidade e me derramar diante do Senhor e ser ouvida, com orientações.

Agradeço ao meu esposo, Sandro E. Balbinot, pelo suporte quando assumiu todas as minhas obrigações nos momentos em que não pude estar presente, principalmente sendo um pai amoroso e cuidadoso. Peço desculpas pelas ausências, mesmo estando por perto. Obrigada pela generosidade, sem você eu não teria alcançado êxito nos estudos. Te amo.

Agradeço as minhas filhinhas, Isadora e Natália, minhas companheiras que, em muitos momentos, me dedicavam massagens, palavras de encorajamento e lanchinhos da tarde, amo vocês. Obrigada pela maturidade e cooperação me incentivando a continuar e não desanimar, pois eu devia ser exemplo!

Agradeço também a minha família que, de certa forma, de tanto me ouvir falar, estão antenados sobre o tema da pesquisa. Camila Saldanha Mafra pelas grandes ajudas, você foi demais, Grazi e Renata. Minha mãe, Marli Vieira Saldanha e meu pai, Sérvulo Gomes Saldanha pelas orações e pelo suporte emocional. Também de forma alguma podia me esquecer da Jajá que foi muito importante nesse período conturbado de idas e voltas entre aeroportos, obrigada pelo teu cuidado comigo. Enfim, a toda minha família que demonstrou paciência diante de tantas ausências.

Agradeço pelo crédito e auxílio do professor Carlos Henrique que, de acordo com sua alçada, me amparou e fez o que pôde para proporcionar condições para que eu pudesse me dedicar aos estudos.

Obrigada a muitos servidores amigos do IFRO, em especial alguns que seguraram as barras pesadas e me ajudaram com sua presteza diante de muita cortesia: Eduardo, Silvano, Sr. Vanderlei, os Professores Rafael Norberto e Rafael Reis, Moisés, Willian Kennedy, Odair Barbizan, Nélio, Ribamar e outros que de algum jeito eu explorei seus saberes e humildade em me ouvir.

Também agradeço a enorme contribuição dos servidores de todos os campi e da Reitoria do IFRO na prestação de informações inerentes a este estudo e o acolhimento, a contribuição de vocês foi de fundamental importância. Agradeço por tê-los conhecido pessoalmente. 
Agradeço a minha Professora orientadora Dra. Lucijane Monteiro de Abreu por sua calma e confiança que, com isso, me transmitia algumas vezes paz e outras, desespero. Também não posso esquecer o professor Dr. Alexandre Nascimento que foi outro que me inspirou a percorrer caminhos fora da minha zona de conforto. Professor, você é uma pessoa exigente, contudo muito generosa, pois mesmo diante de tantas atribuições nunca negou sua atenção, atuando de fato como um verdadeiro professor.

Agradeço também aos amigos que pude ter o prazer de conhecer e o privilégio de conviver durante o período dos encontros. Esse grupo do PPGP foi muito companheiro e solidário. Tivemos uma cumplicidade e um entrosamento muito saudável. Obrigada a todos, assim não me esqueço de ninguém. Agradeço a Rosânia e Juliana, companheiras nos momentos de conquistas e sufocos, obrigada pela ajuda e logística, Ju.

Agradeço ao Grupo de oração pela preocupação e interseção, trazendo ânimo e me amparando nos momentos difíceis. 
Confia no Senhor de todo o teu coração e não te estribes no teu próprio entendimento. Dá instrução ao sábio, e ele se fará mais sábio ainda; ensina ao justo, e ele crescerá na prudência. Provérbios, 3.5 e 9.9 (Bíblia da Mulher que ora) 


\section{RESUMO}

Diante da preocupação na maioria dos países comprometidos com suas agendas ambientais, o desenvolvimento nacional sustentável vem permeando cada vez mais os discursos, documentos e legislações das políticas públicas brasileiras. Com isso, ao que cabem as compras públicas, o Brasil, a partir de 2010, instituiu a Instrução Normativa $\mathrm{n}^{\circ} 10$, que visa estabelecer a inserção de critérios sustentáveis nas compras e contratações da administração pública. Contudo, para o êxito das compras públicas sustentáveis é imperativo saber as dificuldades enfrentadas na implementação e execução dessa ferramenta, já que um dos grandes desafios é estabelecer métodos que auxiliem o gestor a consolidar práticas sustentáveis. Sendo assim, este estudo teve como objetivo identificar os fatores que dificultam a exequibilidade na implementação das compras públicas sustentáveis (CPS) no Instituto Federal de Educação Ciência e Tecnologia de Rondônia (IFRO), uma instituição pertencente à Rede Federal de Educação Profissional e Tecnológica localizada na região amazônica. Para tanto, foi desenvolvida uma pesquisa de base exploratória, com abordagem mista, utilizandose do estudo de caso com múltiplas fontes de evidência, como a percepção dos respondentes envolvidos no processo de compras do IFRO, pesquisa documental, bibliográfica e observação participante. Para os dados coletados foram aplicadas ferramentas estatísticas descritivas e inferenciais, tais como análise fatorial, análise de correlação e teste $U$ de Mann Whitney, contidas no pacote estatístico SPSS. E análise de conteúdo para as questões abertas e aos documentos. Os resultados da pesquisa demonstraram que as dificuldades encontradas foram: pouca familiaridade com as CPS; falta de definição de metas por meio de uma política devidamente institucionalizada, impactando na incerteza sobre o entendimento da compra mais vantajosa e de ferir princípios relacionados à competitividade entre os fornecedores; pouca orientação sobre a inserção de critérios sustentáveis. Contudo foram identificados fatores facilitadores, como os relacionados ao perfil dos servidores; afinidade com o serviço desempenhado; a consolidação da compra compartilhada, o conhecimento de itens passíveis de inserção de critérios sustentáveis e aceitação das CPS pelos servidores. Também foi verificado que a Instituição durante o período de 2010 a 2015 não apresentou a mesma evolução nas CPS, se comparado ao que vem sendo praticado pelo Ministério em que está inserida. As dificuldades encontradas se concentraram no âmbito da gestão organizacional. Esta pesquisa levantou as principais informações quanto aos problemas para a implementação das CPS no IFRO e com isso poderá auxiliar os gestores na tomada de decisão ao que se referem às ações a serem desenvolvidas para o êxito da política pública de desenvolvimento sustentável, atreladas às compras governamentais.

Palavras-chave: Sustentabilidade. Compras Públicas Sustentáveis. Implementação. Políticas Públicas. 


\begin{abstract}
Given the concern in most countries committed to their environmental agendas, sustainable national development is permeating more and more speeches, documents and legislation of Brazilian public policies. Thus, they fit the buying public, Brazil, from 2010, established the Normative Instruction No. 10, which aims to establish the inclusion of sustainability criteria in the procurement and contracting of public administration. However, for the success of sustainable public procurement is imperative to know the difficulties faced in the implementation and execution of this tool, as one of the great challenges is to establish methods that help the manager to consolidate sustainable practices. Thus, this study aimed to identify the factors that hinder the feasibility in the implementation of sustainable public procurement (CPS) at the Federal Institute of Education Science and Rondonia Technology (IFRO), an institution belonging to the Federal Professional Education Network and Technological located in the Amazon region. Therefore, an exploratory basic research was developed with mixed approach, using the case study with multiple sources of evidence, such as the perception of the respondents involved in IFRO the procurement process, documentary research, literature and participant observation. For the data were applied descriptive statistics and inferential tools such as factor analysis, correlation analysis and Mann-Whitney U test, contained in the SPSS statistical package. And content analysis to the open issues and documents. The survey results showed that the difficulties were unfamiliarity with the CPS; lack of definition of goals through a properly institutionalized policy impacting the uncertainty about the understanding of the most advantageous purchase and hurt principles related to competition among suppliers; little guidance on the inclusion of sustainable criteria. However facilitating factors have been identified as related to the profile of servers; affinity for the work performed; the consolidation of shared purchasing, knowledge of items subject to inclusion of sustainable criteria and acceptance of the CPS by servers. It was also found that the institution during the period 2010 to 2015 did not show the same trend in the CPS, compared to what has been practiced by the Ministry in which it operates. The difficulties were concentrated within the organizational management. This research has raised the key information about the problems for the implementation of the CPS in IFRO and this may assist managers in making decisions to which they relate to actions to be undertaken for successful public policy of sustainable development, linked to government procurement .
\end{abstract}

Keywords: Sustainability. Sustainable Public Procurement. Implementation. Public policy. 


\section{LISTA DE FIGURAS}

Figura 1 - Benefício de se comprar das MPE 63

Figura 2 - Evolução do coeficiente de Gini no período de 1976 a 2013 entre os Estados brasileiros 71

Figura 3 - Demonstração da experiência em compras públicas anterior ao IFRO e afinidade com o setor em que está lotado. 95

Figura 4 - Variáveis submetidas à análise fatorial 97

Figura 5 - Familiaridade dos respondentes com as CPS e Interesse e apoio às CPS 101

Figura 6 -Frequência da inclusão de critérios sustentáveis 103

Figura 7 - Grau de concordância sobre as dificuldades na implementação das CPS no IFRO

Figura 8 - Identificação do grau de familiaridade com as CPS por setor de lotação. 110

Figura 9 - Grau de concordância sobre fatores que cooperam para CPS

Figura 10 - Frequência de situações mais recorrentes no IFRO

Figura 11 - Grau de aceitação das CPS na perspectiva pessoal e organizacional 141 


\section{LISTA DE QUADROS}

Quadro 1 - Condições para a compra de produtos da agricultura familiar 67

Quadro 2 - Identificação da missão, visão e valores do IFRO 74

Quadro 3 - Dimensões abordadas pelo questionário adotado na pesquisa 78

Quadro 4 Ferramentas utilizadas para os objetivos da pesquisa 84

Quadro 5 - Materiais e Serviços Demandados e Licitados pela Instituição 88

Quadro 6 - Perfil demográfico e funcional dos respondentes 90

Quadro 7 - Categorias de materiais e serviços passíveis de inclusão de critérios sustentáveis, apontadas pelos servidores do IFRO 102

Quadro 8 - Identificação das abordagens referentes à sustentabilidade no Estatuto do IFRO 


\section{LISTA DE TABELAS}

Tabela 1 - Índice de renda, pobreza e desigualdade de Rondônia 71

Tabela 2 - Participação das CPS no total das compras governamentais e evolução 86

Tabela 3 - Órgãos com valor acima de R\$ 1 milhão nas CPS no período de 2014 a 2015 .. 87

Tabela 4 - Participação das CPS no total das compras governamentais do IFRO no período de 2010 a 2015

Tabela 5 - Matriz anti-imagem para identificação do KMO individual 99

Tabela 6 - Total da variância explicada após a rotação ortogonal e determinação de fatores 100

Tabela 7 - Disposição das variáveis com os devidos valores das cargas fatoriais 100

Tabela 8 - Dificuldades apontadas pelos participantes da pesquisa frente às CPS 104

Tabela 9 - Correlação entre as variáveis: Frequência da inserção de critérios sustentáveis e apoio da alta gestão. 105

Tabela 10 - Fatores que cooperam para o atraso nas licitações do IFRO, na percepção dos servidores

Tabela 11 - Comparativo das medianas das respostas relacionadas à rotina envolvida no processo de compras do IFRO, com os resultados do teste de Mann-Whitney.....

Tabela 12 - Respostas apontadas pelos servidores sobre ações praticadas pela Instituição que fomentam as CPS. 135

Tabela 13 - Resultado da análise de correlação linear das variáveis: Grau de aceitação das CPS pela Instituição e Frequência da inclusão de critérios sustentáveis. 142 


\section{LISTA DE ABREVIATURAS E SIGLAS}

CPS - Compras Públicas Sustentáveis

CATMAT - Catalogação de Materiais

CNE - Conselho Nacional de Educação

CNUMAD - Conferência das Nações Unidas para o Meio Ambiente e Desenvolvimento

CONSUP - Conselho Superior

DAP - Declaração de Aptidão

FAO - Organização das Nações Unidas para a Alimentação

IBGE - Instituto Brasileiro Geografia e Estatística

IES - Instituição de Ensino Superior

IFRO - Instituto Federal de Educação Ciência e Tecnologia de Rondônia

MDS - Ministério do Desenvolvimento Social

MEC - Ministério da Educação

MPOG - Ministério do Planejamento Orçamento e Gestão

NAPNE - Núcleo de Atendimento a Pessoas com Necessidades Educacionais Específicas

OMS - Organização Mundial da Saúde

PAA - Programa de Aquisição de Alimentos

PDI - Plano de Desenvolvimento Institucional

PLS - Plano de Gestão de Logística Sustentável

PMA - Programa Mundial de Alimentos

PNAE - Programa Nacional de Alimentação Escolar

PRONAF - Programa Nacional de Fortalecimento da Agricultura Familiar

PROJUR - Procuradoria Jurídica

SAN - Segurança Alimentar e Nutricional

SEBRAE - Serviço Brasileiro de Apoio às Micro e Pequenas Empresas 
SEPOG - Secretaria de Estado do Planejamento e Coordenação Geral de Rondônia TCU - Tribunal de Contas da União

UASG - Unidades Administrativas de Serviços Gerais

UNESCO - Organização das Nações Unidas para a Educação, a Ciência e a Cultura 


\section{SUMÁRIO}

1 INTRODUÇÃ

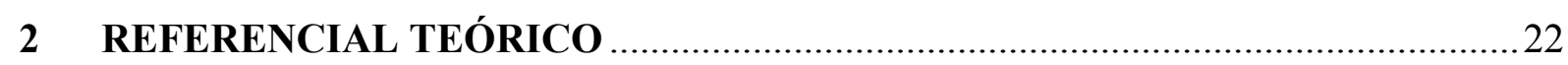

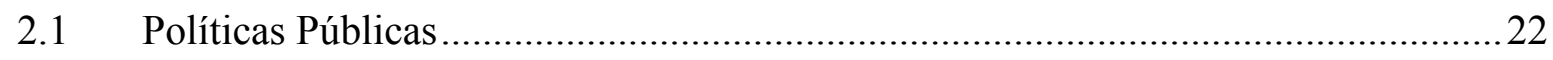

2.1.1 Implementação de Políticas Públicas ..............................................................26

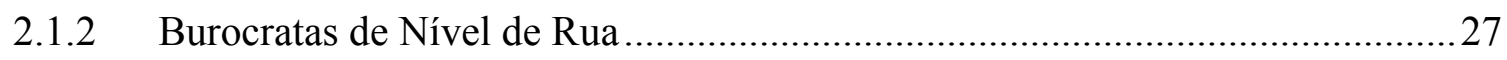

2.2 Política pública de Desenvolvimento Sustentável..............................................29

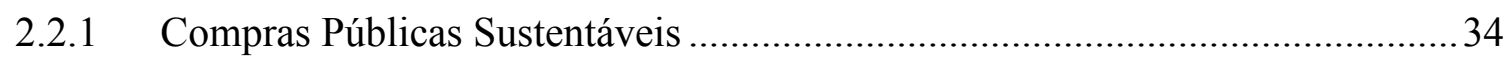

2.2.2 Dificuldades na Implementação das CPS ........................................................ 41

2.3 Ações que Proporcionam a Sustentabilidade nas Compras Públicas ....................... 46

2.3.1 Cultura Organizacional e de Sustentabilidade.................................................. 46

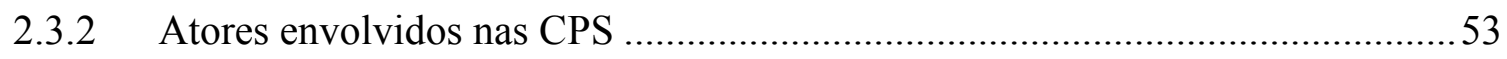

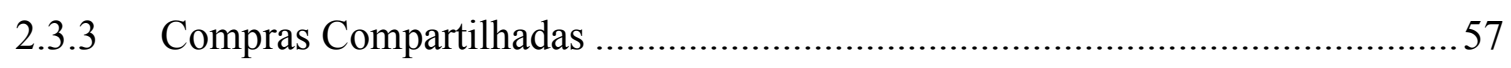

2.3.4 Benefício às Micro e Pequenas Empresas - MPE..............................................59

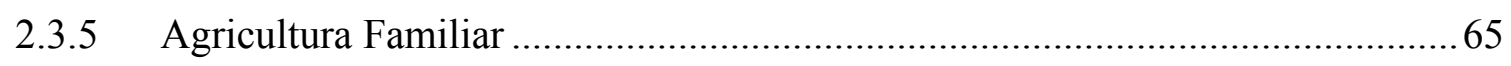

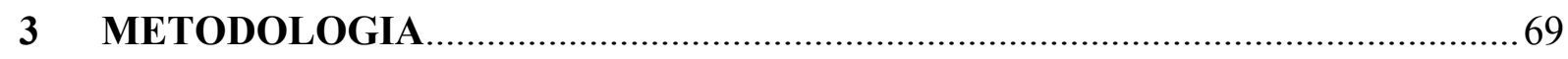

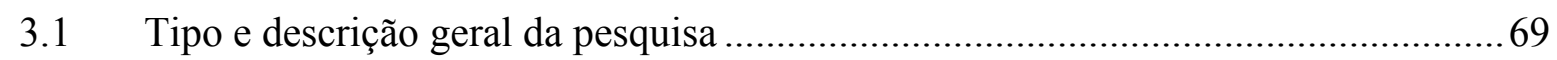

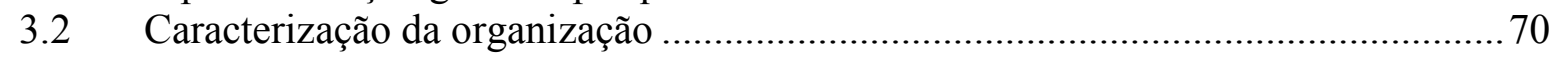

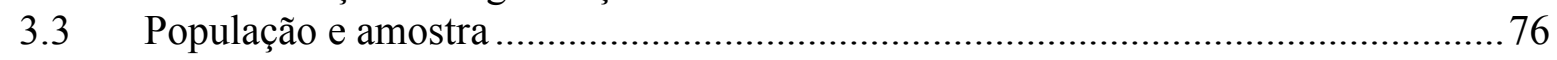

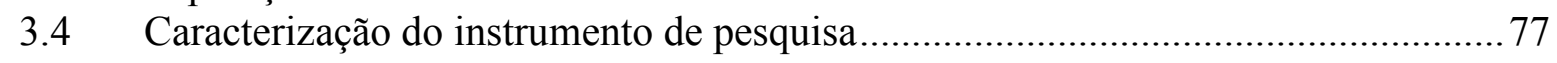

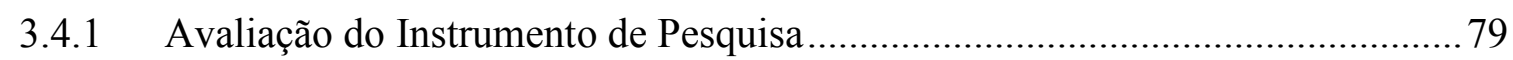

3.5 Procedimentos de coleta e de análise de dados .................................................... 79

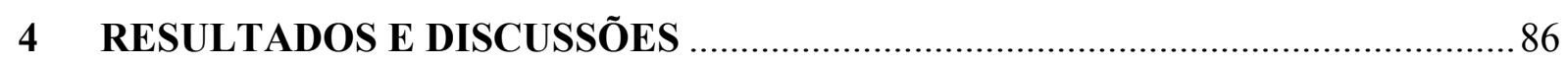

4.1 Evolução das CPS - Panorama das CPS na União e no IFRO .................................86

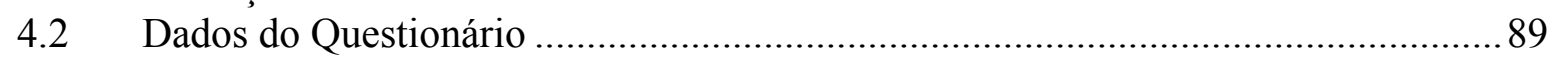

4.2.1 Dimensão - Demográfica e Funcional - Perfil dos Respondentes......................90

4.2.2 Percepção dos Servidores do IFRO em relação às Compras Públicas

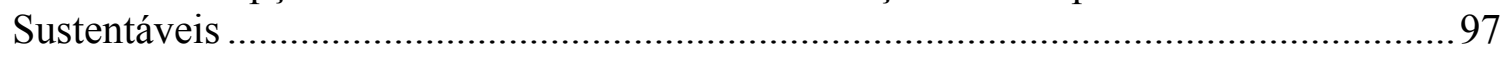

4.2.3 Rotina Envolvida no Processo de Compras - Ações relacionadas às Compras

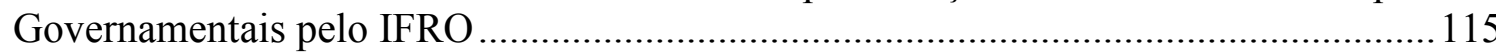

4.2.4 Cultura Organizacional e de Sustentabilidade: identificação de ações que fomentam a Política de Desenvolvimento Sustentável no IFRO ................................... 133

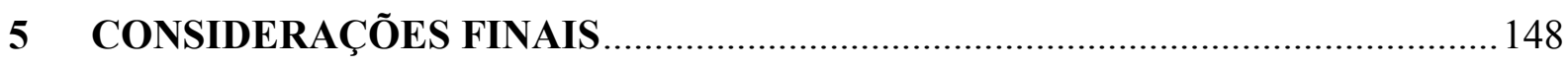

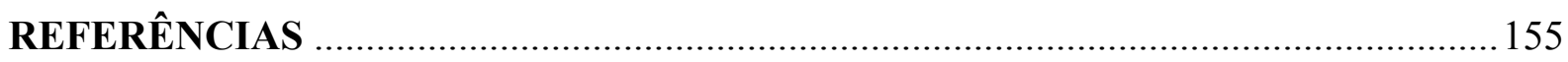

APÊNDICE A - CARTA DE APRESENTAÇÃO DA PESQUISA …................................... 166

APÊNDICE B - QUESTIONÁRIO UTILIZADO NA PESQUISA........................................ 167

APÊNDICE C - FORMAÇÃO, CARGO E EXIGÊNCIA DA TITULAÇÃO DE NÍVEL

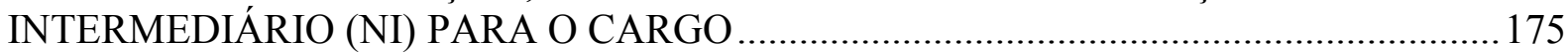


APÊNDICE D - AÇÕES PRATICADAS PELA INSTITUIÇÃO QUE FOMENTAM ÀS CPS, POR UNIDADE DE LOTAÇÃO DOS RESPONDENTES

APÊNDICE E - TESTE ESTATÍSTICO U DE MANN WHITNEY.... 179

APÊNDICE F - GRÁFICO SCREE PLOT DA ANÁLISE FATORIAL 179 


\section{INTRODUÇÃO}

A preocupação na maioria dos países comprometidos com suas agendas ambientais reforça cada vez mais a ideia de sustentabilidade no uso dos recursos naturais nas políticas públicas. No Brasil, sobretudo ao que tange o processo de contratação pública, as compras têm a pretensão de constar em seus arcabouços legais, princípios norteadores relacionados à manutenção da sustentabilidade, a fim de garantir a disponibilidade dos recursos naturais para a posteridade, contemplando a proteção ambiental e sua preservação, proporcionando o desenvolvimento econômico em consonância com a justiça social.

Tendo como os preceitos da Agenda 21, os governos foram chamados por meio dos acordos internacionais a aderir às medidas necessárias para promover o desenvolvimento nacional sustentável. Nesse sentido, uma das contribuições brasileiras pela administração pública foi adotar políticas ambientais e sociais também na conduta das compras governamentais.

Para a Política Pública de Desenvolvimento Nacional Sustentável o governo brasileiro prevê várias ações que, dentre as quais, serão destacadas neste estudo, a saber: as compras públicas sustentáveis (CPS), inclusive por estar sob a responsabilidade da administração pública sua implementação.

A administração pública, designada como atividade administrativa por pessoas e órgãos governamentais, tem como fundamento os princípios constitucionais da legalidade, impessoalidade, moralidade, publicidade e eficiência (BRASIL, 1988). No que se refere às compras, a administração pública atua na gestão de bens e interesses coletivos da sociedade no âmbito federal, estadual e municipal segundo a lei, a moral e a finalidade dos bens entregues à guarda e conservação alheias, visando ao bem comum; o contrário é administração particular (MEIRELLES, 2006). 
Segundo Oliveira e Santos (2015), as compras públicas, além de suprirem as realizações das atividades governamentais atendendo às demandas da sociedade, também desempenham a função de instrumento de política pública em razão de compreender funções de ordem econômica e social.

Ao inserir critérios socioambientais aos tradicionais, relativos às compras, incorporam também fatores sociais e o cuidado com o meio ambiente, pois potencializam as ações da administração pública ao que concerne a sustentabilidade, cumprindo determinações da Constituição Federal da República.

Ao que concerne a influência da política pública sobre o mercado, Oliveira e Santos (2015, p.195), destacam o poder de compra das organizações quando mencionam que "por intermédio da compra sustentável, as organizações públicas poderiam dar um sinal ao mercado a favor da sustentabilidade, passando a escolher bens e serviços alinhando aos critérios atuais, também quesitos socioambientais."

O poder de compra do ente federal movimenta valores consideráveis, variando entre 10 a $20 \%$ do PIB, segundo Silva e Barki (2012), e em razão desse montante a União tem influência para induzir o mercado a se adequar às mudanças, cumprindo com isso uma das funções econômicas do Estado, ou seja, a função estabilizadora.

Sendo assim, o Estado a fim de corrigir ou minimizar os efeitos das chamadas falhas de mercado pode lançar mão de mecanismos econômicos e fiscais. Dentre os mecanismos usados pelo Estado para promover o crescimento, garantir emprego ou combater a inflação tem-se os juros, preços, taxa de câmbio, impostos e, ainda os gastos públicos coordenados (COSTIN, 2010).

No entanto, sabe-se que a implementação de uma política pública não funciona exatamente como formulada, necessitando no decorrer de sua execução, de acompanhamento, avaliação e adequação para conseguir atingir o objetivo almejado. 
Nesse sentido, na busca de informações relacionada à gestão, sobre quais fatores dificultam a exeqüibilidade das compras públicas sustentáveis, é necessário primeiramente conhecer o problema, a causa, os envolvidos, o grau de dificuldade, o impacto, dentre outras variáveis específicas à questão para atuar na solução ou mitigação dos problemas ora encontrados.

Quanto a conhecer os problemas da organização, Bilhim (2002, p.48) afirma que "quando encaramos, pensamos e vivemos a empresa onde trabalhamos como um ente vivo, estamos em condições de iniciar programas de aprendizagem, e para haver aprendizagem organizacional é preciso que a própria empresa se veja no seu todo".

O presente estudo também poderá servir de suporte para outras organizações, já que as dificuldades na implementação das CPS são semelhantes e a obrigatoriedade da implementação é para todos os órgãos que efetuam licitações públicas.

Bittencourt (2014) reforça a importância do presente estudo ao demonstrar que, apesar dos sinais de benefícios da prática das CPS, muitos são os desafios para sua implementação, dentre eles, de convencer os tomadores de decisão dos impactos positivos que essa ação proporciona.

Alencastro; Silva e Lopes (2014) mencionaram a respeito da inexistência de estudos científicos sobre os impactos, limites e potencialidades da inserção de critérios de sustentabilidade nas contratações públicas brasileiras, enquanto instrumento de política pública ambiental, o que também contribuiu para a escolha do problema desta pesquisa.

As informações levantadas neste estudo auxiliarão os gestores na tomada de decisão para solução dos problemas da implementação e execução da política de desenvolvimento nacional sustentável que envolve as compras do Instituto Federal de Rondônia (IFRO), uma autarquia que desempenha atividades na área de ensino pesquisa e extensão de âmbito 
Federal, localizada no Estado de Rondônia, em parte da Amazônia Ocidental, na Região Norte do Brasil.

Com o foco na necessidade do IFRO, em entender suas limitações para o desempenho e aplicabilidade da Política Nacional de Desenvolvimento Sustentável amparado pelas compras públicas, despertou-se o interesse em identificar as dificuldades percebidas pelos servidores envolvidos nos processos de compras da Instituição e confrontá-las com as da literatura.

Estudar a temática das Compras Públicas Sustentáveis no IFRO, atrelada à gestão pública foi uma necessidade a fim de aproximar a realidade vivenciada por uma instituição de ensino da rede pública federal brasileira, quanto à implementação de uma política pública de desenvolvimento sustentável, considerando as exposições teóricas e conceituais do ambiente acadêmico e sua aplicação funcional. Como apontado por Peters e Pierre (2010), a gestão pública está na interseção entre teoria e prática.

O IFRO foi escolhido como órgão a ser investigado, pela familiaridade de sua estrutura, pela necessidade de se levantar a questão das compras sustentáveis em uma instituição que tem como premissa as sustentabilidade e, ainda, por estar localizado na Região Norte do Brasil, quase que totalmente dentro da Amazônia, considerado o maior bioma do Brasil e detentor da maior bacia hidrográfica e de biodiversidade do mundo, portanto região de interesse mundial, dada suas riquezas naturais.

Diante dessas considerações, justifica-se o estudo em questão pela pressão da Instituição em se tornar sustentável e da responsabilidade em gerenciar seus processos de aquisição e contratação de serviços sob a luz da sustentabilidade. Todavia, é sabido que todo impacto direto ou indireto causado pelo consumo e demais ações promovidas pela Instituição podem afetar positiva ou negativamente os recursos naturais e os aspectos sociais e econômicos, no âmbito local e regional. 
Sendo assim, no intuito de proporcionar informações aos servidores de como estão inseridas as compras públicas sustentáveis (CPS), este estudo tem como objetivo identificar os fatores que dificultam a exequibilidade na implementação das CPS no IFRO. E com esse propósito os objetivos específicos definidos foram:

a. Analisar a evolução das compras públicas sustentáveis no IFRO;

b. Descrever o perfil dos servidores que estão envolvidos aos processos de compras governamentais no IFRO

c. Avaliar a percepção dos servidores do IFRO em relação às CPS e identificar as principais dificuldades na implementação das CPS;

d. Analisar as ações relacionadas às compras governamentais do IFRO;

e. Analisar a cultura organizacional quanto à cultura de sustentabilidade no IFRO; 


\section{REFERENCIAL TEÓRICO}

\subsection{Políticas Públicas}

Embora não seja objeto deste estudo o aprofundamento sobre as políticas públicas, não há como estudar os fatores que dificultam a exequibilidade na implementação das CPS, sem adentrar nesta seara, pois o tema pode ser considerado multifacetado em razão de sua característica apresentar amplas abordagens, portanto quanto mais afunilado estiver o estudo, mais compreensível será o entendimento. Brasil (2014a) afirma que:

Por meio das Políticas Públicas o Estado pode realizar os fins previstos na Constituição Federal, atendendo aos direitos fundamentais que necessitam de iniciativas estratégicas para serem alcançados. Nessas condições, é possível considerar as licitações sustentáveis como instrumentos de Políticas Públicas para consolidar o direito fundamental do desenvolvimento sustentável (BRASIL, 2014a, p.21).

Souza (2007) argumenta que, diante da repercussão que a política pública assume na economia e na sociedade, é necessário explicar suas inter-relações entre Estado, política, economia e sociedade, razão que justifica o interesse comum da área por pesquisadores de disciplinas distintas, como economia, ciência política, sociologia, antropologia, geografia, planejamento, gestão e ciências sociais aplicadas.

Nesse sentido, faz-se necessário esclarecer o conceito de políticas públicas, já pacificado entre o meio científico como sendo a tomada de decisões, como a escolha do fazer ou não fazer, ou seja, é a materialização do agir (DYE, 1984, apud SOUZA, 2007).

Souza (2007, p.69), ressalta a afirmação quando diz que a "formulação de políticas públicas constitui-se no estágio em que governos democráticos traduzem seus propósitos e plataformas eleitorais em programas e ações que produzirão resultados ou mudanças no mundo real".

Vale frisar que uma política pública, especialmente as sociais, tem origem geralmente a partir de um conflito, uma crise econômica e ou social, Maciel (2007). Confirmando, portanto, possivelmente a hipótese que a origem da política pública de desenvolvimento 
sustentável tenha ocorrido após uma forte demanda social, com a implicação direta dos movimentos ambientalistas iniciados em 1968, em que o tema em questão culminou em agendas internacionais devidamente institucionalizadas.

Secchi (2013) menciona que as necessidades de formulação de políticas públicas se fazem precipuamente pela identificação e definição do problema ou questão e, constitui ponto crucial para iniciar a análise e o entendimento da articulação e objetivos que se pretendem em uma intervenção. Farah (2006) concorda com a afirmação, quando ressalta que:

[...] ao analisar o processo de formação da agenda governamental, a existência de uma condição objetiva não é fator suficiente para colocar um tema na agenda pública. É necessário, primeiramente, que esta condição seja considerada um problema social, o que significa um problema para a sociedade (ou para segmentos ou grupos da sociedade) e, sobretudo, um problema que deve ser resolvido pela sociedade e pelos governos. (FARAH, 2006, p.2)

Seguindo nesta linha, entende-se que é por meio das políticas públicas que o estado pode intervir no cumprimento dos direitos constitucionais, garantindo com isso a discussão e inserção de recursos para atendimento das políticas inseridas na agenda governamental. Para Secchi (2013), é após a fase de identificação e delimitação do problema e suas possibilidades de enfrentamento que se chega à avaliação dos recursos disponíveis destinados à política, o que implicará em ações e a resultados sobre a efetividade da mesma.

Souza (2007), numa explanação sobre o ciclo da política pública, considera que os estágios de definição da agenda são constituídos de identificação de alternativas aos problemas; avaliação das opções; seleção das opções, implementação e avaliação. Assim, algumas questões entram na agenda governamental em detrimento de outras, porque o foco recai primeiramente no problema e não na política propriamente dita, construindo assim a consciência coletiva. Fator poderoso para a definição da agenda; e, em seguida focaliza os participantes.

Esses participantes são classificados como visíveis, os políticos, mídia, partidos, grupos de pressão e outros, e os invisíveis, os acadêmicos e a burocracia. Nesta perspectiva, 
os participantes visíveis são os que definem a agenda e os invisíveis, as alternativas. Porém Kingdon (2003, apud CAPELLA, 2007) não considera a mídia como um instrumento poderoso na formulação da agenda, mesmo que seja considerado um ator visível.

$\mathrm{Na}$ arena social, para que uma determinada circunstância ou evento se transforme em um problema, é preciso que as pessoas se convençam de que algo precisa ser feito. Para isso, três principais mecanismos chamam a atenção dos formuladores de política pública: divulgação de indicadores; desastres ou repetição continuada do problema; e informações que mostram as falhas da política atual ou seus resultados medíocres. (SOUZA, 2007).

Seguindo a trajetória das pressões ambientais, cabe mencionar o que consta no Relatório do Brasil para a Conferência das Nações Unidas sobre o meio ambiente e desenvolvimento (CIMA, 1991):

\begin{abstract}
A incorporação do marco ecológico ao processo de decisões governamentais para levar em conta as implicações das políticas públicas sobre a rede de relações que opera os ecossistemas constitui mais do que uma aspiração, uma necessidade biológica para a própria manutenção dos sistemas naturais que tornam possível a vida. (CIMA, 1991, p.14)
\end{abstract}

Com a modernização do Estado brasileiro na década de 90, o cenário voltou-se para a proposição de políticas públicas que fomentassem o desenvolvimento, com incremento da infraestrutura e da logística, aproveitando o uso do território de acordo com vocações e oportunidade de negócio. Contudo, no setor do meio ambiente, esse processo de modernização do Estado brasileiro trouxe a perspectiva da abordagem da variável ambiental como condicionante. (TEIXEIRA, 2008).

Segundo Radin (2010), a alteração do cenário do setor público ocorreu em razão do aumento das atividades que atravessam fronteiras. Haja vista que antes essas atividades eram definidas e estabelecidas com demarcações claras de políticas e programas específicos, tratadas fragmentadamente; e que agora são interdependentes, envolvidas numa rede de conjunturas associadas. 
Um exemplo das atividades que atravessam fronteiras, são as políticas rurais que anteriormente eram definidas como parte das políticas agrícolas no século $\mathrm{XX}$, e que, nesse período muitos países verificaram que a política rural não se enquadrava exclusivamente dentro da esfera da agricultura e sim dentro de outras políticas relacionadas, como o desenvolvimento econômico, saúde, educação, moradia e infraestrutura (RADIN, 2010)

Esse exemplo configura a contemporaneidade com a política de sustentabilidade ambiental que interage e dialoga com outras políticas sistematicamente relacionadas, confirmando que as atividades atravessaram as fronteiras e caracterizaram como mutáveis e dinâmicas, com a necessidade de ajuste à realidade mais complexa e exigente da sociedade e da gestão. Com isso, o papel do governo teve que ser redesenhado para atender as demandas emergentes dessa alteração, conforme destaca Radin (2010):

O desenvolvimento inicial da gestão intergovernamental representou o reconhecimento de que muitas políticas e programas requeriam atividades que ultrapassassem um único nível de governo ou uma única jurisdição, levando alternativas da autoridade governamental autônoma e separada. (RADIN, 2010, p.599).

Enfim, não só as políticas foram se inter-relacionando como também os governos entre seus níveis tiveram que se empenhar conjuntamente com um propósito comum de dar prosseguimento ao programa ou a política estipulada e, com isso essa interdependência convergiu para um comprometimento inclusive entre o setor público e privado. (FOGLIATTI et al., 2008)

Trazendo a questão da interdependência para este estudo, pode ser observada na política de sustentabilidade ambiental, a necessidade do comprometimento dos fornecedores com as compras públicas sustentáveis, principalmente ao incluírem na cadeia de insumos e serviços os critérios socioambientais, porém, para a efetivação das ações de políticas públicas formuladas, as mesmas devem ser primeiramente implementadas. 


\subsubsection{Implementação de Políticas Públicas}

Em virtude de controvérsias entre o termo implementação utilizado nos estudos, geralmente sendo caracterizado tanto como processo, como produto do processo e, em algumas vezes ainda, até como resultado desse processo, o conceito de implementação adotado neste estudo foi o defendido por Lester e Goggin (1998 apud WINTER, 2010, p.219), "que veem a implementação como um processo, como uma série de decisões e ações regionais direcionadas para colocar em vigor uma decisão existente de autoridade federal”.

Segundo Souza (2007), um dos elementos principais das diversas definições e modelos sobre políticas públicas, é que a política pública permite distinguir entre o que o governo pretende fazer e o que, de fato, faz. Outro elemento é que envolvem vários atores e processos subseqüentes que, após sua decisão e proposição, implica implementação, execução e avaliação, resultando assim em estudos que focalizam processos, atores e a construção de regras.

O estudo das organizações públicas a partir da perspectiva das políticas públicas “contribui muito para nossa compreensão sobre o modo como as organizações funcionam e como podem contribuir para a formulação e implementação efetiva das políticas" (BRYNER, 2010, p.330)

Peters e Pierre (2010), na introdução da obra, coletânea sobre Administração Pública, indicam a necessidade da abordagem sobre o estudo e a importância da gestão pública, principalmente dentro das organizações e consideram que, na burocracia, as organizações além de desempenharem funções administrativas têm seus próprios interesses e representam os interesses de seus clientes. Salientam que os legisladores e as autoridades podem aprovar as leis que desejarem, mas se essas leis não forem geridas com efetividade pela burocracia pública, representada, neste caso pelos servidores e as organizações, pouco ou nada, irão de fato ocorrer. 
Bryner (2010, p.315), aponta que a "principal tarefa das organizações públicas é implementar as políticas aprovadas pelos governos e desempenhar papéis importantes na formação dos sistemas políticos em geral, porém o êxito das políticas está particularmente entrelaçado à capacidade administrativa". Afirma que a implementação é a continuação da formulação de políticas, mas com novos atores, procedimentos e ambientes institucionais.

Outra importante característica é a da visibilidade, pois o profissional da linha de frente é o ponto de contato entre o cidadão e o Estado, sem, portanto, a presença dos representantes eleitos. Todavia, esse contato entre o Estado e a sociedade gera duas informações ao governo: a primeira, é que a implementação da lei é efetuada pelos escalões inferiores da burocracia e, a segunda é que são eles que definem o que as leis efetivamente representam para os cidadãos.

Considerando, nesse caso, que o implementado é o que foi aplicado, e não necessariamente o que foi formulado, esses servidores dos escalões inferiores são os que de fato exercem substancial discricionariedade, já que atuam e decidem como essa implementação deve ocorrer. Por exemplo, quem obtém o quê do governo. (PETERS; PIERRE, 2010).

O resultado gerado dessa interação é a imagem do governo para a população, pois segundo como a população é atendida ou tratada, vai ser o que o governo representa. Essa abordagem remete ao contexto referente aos burocratas de linha de frente, ou de nível de rua como também são chamados pelos pesquisadores dessa área.

\subsubsection{Burocratas de Nível de Rua}

Uma corrente formada por pesquisadores com interesse em implementação de baixo para cima, (menores escalões), isto é, no ponto em que o setor público encontra os cidadãos e 
as empresas, esses estudiosos, argumentam que os trabalhadores de campo ou de linha de frente como são chamados, estão diretamente ligados nos atendimentos dos cidadãos. São eles: os professores; policiais; carteiros; médicos; enfermeiros e vários outros que assumem a condição de tomadores de decisão (WINTER, 2010).

Para Meyers e Vorsanger (2010), no entremeio do Estado e os cidadãos, os burocratas de nível de rua têm oportunidades significativas de influenciar a execução das políticas públicas. Superando inclusive sua autoridade formal, pois quando interpretam regras e alocam recursos escassos em sua rotina e por meio das decisões, produzem políticas públicas tal como os cidadãos as experimentam (LIPSKI, 1980, apud MEYERS; VORSANGER, 2010).

Os burocratas de nível de rua exercem um poder discricionário na prestação de serviços ou na aplicação de regulamentações que os tornam atores essenciais na implementação de políticas públicas, já que atuam inclusive como formuladores de políticas no momento que estão decidindo ou tratando diretamente com o público. Quando decidem o que pode ou não ser concedido, ou o que deve ou não ser feito (LIPSKI 1980, apud WINTER, 2010).

Winter (2010, p.212) explica que os profissionais "tentam fazer o melhor possível, porém experimentam uma lacuna entre as demandas deles exigidas e sua intensa carga de trabalho, e nessa situação aplicam uma série de mecanismos de abordagem que sistematicamente distorcem seu trabalho em relação às intenções da legislação".

Trazendo a questão do poder discricionário exercido pelos profissionais de linha de frente para esta pesquisa, Santos e Barki (2011) afirmam que ao especificar um bem ou serviço a ser licitado, o servidor exerce esse poder discricionário, quando escolhe os critérios técnicos que venham atender a necessidade administrativa, atuando naquele momento com o seu poder de decisão. 
Contribuindo no entendimento, Meyers e Vorsanger (2010, p.267) enfatizam que “pesquisadores com orientação teórica mais forte estão aumentando a compreensão do modo como os burocratas de nível de rua entendem seus ambientes - e como esses processos de entendimento informam e orientam seu comportamento cotidiano".

Complementam que, conceder maior importância às atividades e a influência dos burocratas de nível de rua, enriquecerá a compreensão sobre êxitos e fracassos na implementação, porém atribuir-lhes exclusivamente essas responsabilidades podem desviar a análise dos fatores políticos, projetos de políticas e organizacionais que modelam suas ações.

É neste contexto que cabe dotar aos servidores que desempenham as atividades relacionadas ao processo de compras do IFRO, de instrumentos para servir de apoio ao desempenho das CPS. Cumprindo além da legislação, a adoção de uma visão holística para identificar fatores socioambientais que possam ser embutidos no processo de compras, como meio de mitigar as dificuldades na implementação das CPS, uma das ferramentas da Política Pública de Desenvolvimento Sustentável.

\subsection{Política pública de Desenvolvimento Sustentável}

Na busca pelo desenvolvimento sustentável, "foi iniciada na década de 1970 um modelo alternativo de desenvolvimento que estimulasse o crescimento econômico e ao mesmo tempo promovesse a manutenção e melhoria da qualidade de vida" Watanabe (2011, p.81). Pois, a partir dessa década, a consciência relacionada aos efeitos da degradação ambiental se revelou em proporção perceptível e foi colocada em discussão a questão do modelo de desenvolvimento econômico contemporâneo em relação à queda da qualidade ambiental, causando com isso um despertar para a reflexão à adoção de modelos sustentáveis na vida da população. 
Essa conscientização possivelmente tenha sido provocada pelos movimentos ambientalistas internacionais que se fizeram presentes, pois tinham como objetivo informar sobre os agravos aos problemas ambientais advindo de uma falta de zelo com o meio ambiente, combinado com um consumismo exacerbado provocado por grandes mudanças no modo de vida da sociedade. Souza (2000) destaca a intensificação ao modelo de produção em massa, que colaborou para aumentar o consumo de recursos e os efeitos negativos sobre o meio ambiente.

Veiga (2008), destaca que desenvolvimento passou a ser utilizado em oposição ao modelo de crescimento econômico consolidado, a partir da revolução industrial, que até então, era voltado apenas para o aumento da produtividade e da renda per capita, sem considerar outros fatores como os de ordem social e ambiental. O autor também coaduna com Souza (1999) quando caracteriza o desenvolvimento, em sentido amplo, como uma mudança qualitativa significativa, o que geralmente acontece de forma cumulativa.

A Conferência de Estocolmo, realizada em 1972 foi a primeira Conferência Global voltada para a temática ambiental. Trouxe como um dos princípios propostos, o direito humano ao meio ambiente equilibrado e o dever de preservá-lo para todas as gerações, iniciando a inserção de informações, mesmo que muito tímida para a consciência quanto à sustentabilidade.

A definição de sustentabilidade se consolidou junto com o conceito de desenvolvimento sustentável, como aquele que satisfaz às necessidades das gerações atuais sem comprometer a capacidade das gerações futuras de satisfazer suas próprias necessidades, em 1987 quando a ONU publicou o relatório de Brundtland.

Com o Relatório Brundtland, foi apresentada uma lista de ações a serem adotadas pelas nações e definidas as metas a serem atingidas em nível global, pois não havia qualquer ação que realmente mantivesse um comprometimento com a proposta desse novo modelo de 
desenvolvimento. No entanto isso também não foi suficiente para o alcance da sustentabilidade. Ainda era necessário definir as estratégias de ação para facilitar o cumprimento das metas estipuladas (WATANABE, 2011).

No Brasil as políticas ambientais tiveram início antes mesmo dessa magnitude de preocupação dos movimentos ambientalistas. A partir de 1930 foi elaborado o primeiro código florestal, por meio do Decreto 23.793, de 1934 que contribuiu para a criação dos Parques: Nacional Brasileiro de Itatiaia; Parque Nacional do Iguaçu e o da Serra dos Órgãos, todos nessa década. Contudo, a política preservacionista que tinha como premissa a proteção dos ecossistemas florestais ficou em segundo plano nas décadas de 40 e 50 em função da industrialização e do desenvolvimento acelerado (PRZYBYSZ; NAVROSKI; WAGNER, 2012).

Segundo Teixeira (2008), foi a partir da década de 90 que a questão ambiental ganhou centralidade na esfera internacional, motivada pelo debate sobre a sustentabilidade dos processos de desenvolvimento, o que culminou em uma nova base de negociação e de cooperação entre os países.

Nesta época, o Brasil sediou a Conferência das Nações Unidas para o Meio Ambiente e Desenvolvimento (CNUMAD), mais popularmente chamada de ECO 92. A Conferência trouxe novamente, porém de uma forma mais incisiva, a conscientização e a formulação de políticas públicas ambientais que pudessem versar sobre a questão ambiental com a participação de uma sociedade mais informada em relação às políticas públicas, principalmente às ambientais.

Sendo assim, o instrumento que realmente foi um alerta e um comprometimento quanto às metas rumo à sustentabilidade pelas nações foi a Agenda 21, que ficou estabelecida uma direção para atingir o crescimento econômico, sem comprometer o atendimento das gerações futuras. 
A Agenda 21 recebeu esse nome em razão da preocupação com a condição do planeta no século XXI, enfatizando os recursos naturais e a necessidade de adoção de ferramentas que respondessem às demandas da população, sem comprometer as gerações futuras. (PRZYBYSZ; NAVROSKI; WAGNER, 2012).

Após a Conferência da Rio 92, a política ambiental brasileira deu um salto qualitativo quando aprovou a Lei 9.605/1998 (Lei de Crimes Ambientais ou Lei da Natureza), criando um instrumento que garantia a eficácia e agilidade na punição aos infratores do meio ambiente.

No capítulo quatro da Agenda 21, que trata das mudanças nos padrões de consumo, desenvolvimento de políticas e estratégias nacionais para estimular mudanças nos padrões insustentáveis de consumo, o Brasil como país signatário dos acordos mantidos se comprometeu a criar ferramentas para que viesse atender a necessidade levantada na questão relacionada ao consumo em função do impacto ambiental, social e econômico.

Bittencourt (2014), também mencionou o capítulo 4, inclusive salientou que para o desenvolvimento de uma melhor compreensão do papel do consumo, como a forma de implementar padrões sustentáveis; os governos deverão estimular o surgimento de um público consumidor informado.

De acordo com Przybysz; Navroski; Wagner, (2012, p.69) "além das questões ambientais, tecnológicas e econômicas, o desenvolvimento sustentável tem uma dimensão cultural e política que vai exigir a participação democrática de todos na tomada de decisões para as mudanças que serão necessárias”, pois para o seu alcance é imprescindível pensar como se vive, se produz e se consome.

Segundo Fogliatti et al. (2008), os movimentos ambientalistas ocorridos na década de 60 até a Conferência em Johanesburgo, na África do Sul, em 2002, fez com que muitos países despertassem para as questões políticas de desenvolvimento econômico relacionado às 
questões ambientais, e agiram instituindo políticas, criando agências de proteção, adotando posturas proativas em defesa ao meio ambiente, inclusive integrando agentes públicos e privados:

\begin{abstract}
Atualmente, as políticas ambientais procuram conciliar o desenvolvimento com o uso sustentável dos recursos naturais, agregando os instrumentos de comando e controle, tradicionalmente aplicados aos instrumentos econômicos, buscando-se a integração dos agentes públicos e privados na gestão dos recursos naturais com a implementação de ações conjuntas de preservação ambiental. (FOGLIATTI et al., 2008 p.17)
\end{abstract}

Entretanto essa visão de integração não foi percebida por 31\% dos 450 respondentes de uma pesquisa ocorrida no VI Congresso Internacional Sustentável, em setembro de 2013, organizado pelo Conselho Empresarial Brasileiro para o Desenvolvimento Sustentável (CEBDS), no Rio de Janeiro, pois foi justamente a falta de articulação entre empresas, sociedade e governo, considerada o principal entrave às ações de sustentabilidade no mundo corporativo (BITTENCOURT, 2014).

Para o Ministério do Planejamento Orçamento e Gestão (MPOG), a noção de sustentabilidade é baseada na necessidade de se garantir a disponibilidade dos recursos da Terra hoje, assim como para nossos descendentes, por meio de uma gestão que contemple a proteção ambiental, a justiça social e o desenvolvimento econômico equilibrado de nossas sociedades (Brasil, 2014a).

Em se tratando das dimensões da sustentabilidade, segundo Bittencourt (2014) as seis principais são: social, espacial, cultural, política, econômica e ambiental.

- A social tem como maior objetivo uma civilização com igualdade no acesso aos recursos e serviços sociais, com possibilidade de trabalho que assegure a qualidade de vida e equidade na distribuição de renda, por exemplo. Oliveira e Santos (2015) ainda ampliam esses objetivos, também para condições de trabalho e direitos humanos.

- A espacial está relacionada à melhor distribuição territorial dos assentamentos humanos. 
- A cultural consiste na busca pelo equilíbrio entre o respeito à tradição e a inovação, com valorização da diversidade das culturas locais, respeitando as especificidades de cada ecossistema.

- A política objetiva o fortalecimento das instituições democráticas e da cidadania ativa.

- A econômica está relacionada à gestão eficiente dos recursos econômicos, ou seja, quando o emprego de recursos financeiros não está simplesmente baseado na obtenção do lucro, mas em torno de outros aspectos que possam ser passíveis de considerações, como por exemplo, custo-benefício, preço, qualidade, disponibilidade, funcionalidade (BITTENCOURT, 2014; OLIVEIRA; SANTOS, 2015; COSTA, 2012).

- E a ambiental que busca a utilização dos recursos naturais, zelando pela sua permanência e aplicação futura.

Przybysz; Navroski; Wagner (2012), assim como Lavorato (2013), concordam quanto às dimensões da sustentabilidade que, além das questões ambientais, sociais, tecnológicas e econômicas, o desenvolvimento sustentável tem uma dimensão cultural e política que vai exigir a participação democrática na tomada de decisões para as transformações necessárias.

As contribuições direcionadas à sustentabilidade podem ser confirmadas no próprio ordenamento constitucional brasileiro, nas políticas instituídas no país, bem como nas legislações, cumprindo assim as exigências de observações e requisitos referentes à sustentabilidade inclusive nas contratações, criando as chamadas compras públicas sustentáveis.

\subsubsection{Compras Públicas Sustentáveis}

Com o Decreto Federal n ${ }^{\circ}$ 2.926, de 1862, do então Ministério da Agricultura, Comércio e Obras Públicas, o Brasil iniciou a regulamentação acerca das normas sobre 
procedimento de compras públicas, porém somente após diversas outras leis, o procedimento da licitação foi consolidado por meio do Código de Contabilidade da União, mediante o Decreto $n^{\circ} 4.536$, de 1922 (COSTIN, 2010)

Foi a partir do Código de Contabilidade que o procedimento de compras públicas evoluiu até o Decreto-Lei no 200, de 1967, que também estabeleceu a reforma administrativa federal e sistematizou as compras públicas, estendendo posteriormente às administrações dos Estados e Municípios.

No entanto, somente em 1986, pelo Decreto $\mathrm{n}^{\circ} 2.300$ que foi instituído pela primeira vez, o Estatuto Jurídico das Licitações e Contratos Administrativos, quando posteriormente foi alterado e estabelecidas as hipóteses das modalidades de dispensa e inexigibilidade de licitações, bem como as demais: concorrência; tomada de preços; concurso; leilão e convite.

Com o objetivo de conferir maior eficiência e racionalidade para as contratações públicas, desde a sua trajetória inicial, as compras sofrem de autonomia, pois dependem de muitos fatores relacionados ao controle, em razão dos elevados casos de fraudes e corrupção em benefício próprio. Isso acarreta a um processo oneroso, complexo e cheio de incertezas ao que se pode ou ao que se deve efetuar para o cumprimento da legislação ou jurisprudências, deixando em várias ocasiões de se obter êxito, por receio de estar ferindo algum princípio.

O combate à corrupção sempre foi o ponto central dos debates e das ações governamentais no setor, com isso o potencial gerador de desenvolvimento econômico e social das compras públicas foi sempre suplantado por uma mentalidade centrada no controle dos processos em detrimento dos resultados. (BRASIL, 2013a)

Diante dessas considerações sobre o tema, pode ser observado historicamente que as compras sempre tiveram um status de área meio, ao atender ao provimento de bens, serviços e obras necessárias à execução e funcionamento das políticas públicas. Em outras palavras, 
servir apenas para adquirir bens e serviços, de forma rápida, transparente e com o menor preço, a partir de um padrão pré-estabelecido de qualidade e desempenho, numa visão normativista (BRASIL, 2013a).

As compras e contratações públicas brasileiras são regidas pela Constituição Federal de 1988 (CF) conforme artigo 37, inciso XXI e regulamentadas pela Lei de Licitações e Contratos, (Lei 8.666 de 1993), que estabelece normas gerais sobre licitações e contratos administrativos pertinentes às compras, obras, serviços, inclusive de publicidade, alienações e locações no âmbito dos poderes, tanto da União, como Estados, Distrito Federal e dos Municípios (COSTIN, 2010; TCU, 2010).

A licitação é o meio formal e legal que indica como será a escolha do fornecedor para atender à administração pública sem que ocorram benefícios ou favorecimentos a um, em detrimento de outro, buscando garantir a participação igualitária, reduzindo a discricionariedade do poder público, a fim de evitar escolhas que tenham outro foco que não o interesse público (COSTIN, 2010).

Justen Filho (2010, p.251) define licitação, como um procedimento administrativo “que envolve a realização de diversas atividades materiais, a cargo de uma pluralidade de agentes públicos e envolvendo um número variável de particulares. Essa sucessão de atos poderá materializar-se em diferentes locais geográficos, a depender do objeto da atuação pública ou privada”.

As Leis $n^{\circ} 8.666 / 93$ e $n^{\circ}$ 10.520/2002 (Lei do Pregão) constituem a legislação básica sobre licitações e contratos para a Administração Pública. A Licitação é um procedimento administrativo formal em que a Administração Pública convoca, por meio de condições estabelecidas em ato próprio, edital ou convite, empresas interessadas na apresentação de propostas para o oferecimento de bens e serviços. (TCU, 2010). 
Dentre as modalidades de licitação brasileira, tem-se carta convite, tomada de preço, concorrência, concurso, leilão e pregão. Para este estudo foi dada a relevância ao pregão em função dos fatores relacionados ao alto índice de utilização, conforme as estatísticas demonstradas pelo portal de compras governamentais, e por ser também a modalidade mais empregada no IFRO, já que contempla uma característica peculiar de se associar a essa modalidade, a adesão às compras, também chamadas de compras compartilhadas ou compras conjuntas.

Câmara e Frossard (2010 apud OLIVEIRA; SANTOS, 2015, pag.194) argumentam que "a perspectiva acadêmica tradicional, orientada preponderantemente por uma perspectiva econômica, vê as compras apenas como instrumento que supre a administração dos bens necessários à execução das políticas públicas e ao seu funcionamento regular.”

Já numa perspectiva mais genérica, o Ministério do Planejamento, Orçamento e Gestão, informa que as CPS induzem a novos mercados e fomentam novas práticas de produção e consumo que visam melhorar a eficiência no uso de produtos e recursos naturais, econômicos e humanos, reduzindo o impacto sobre o meio ambiente e promovendo a igualdade social e consequentemente a redução da pobreza. (BRASIL, 2010)

Segundo Alencastro; Silva e Lopes (2014), na perspectiva da Comissão Europeia, as CPS não consideram apenas o preço dos bens e serviços, como forma mais vantajosa para a administração pública, mas consideram fatores como qualidade, eficiência, proteção ambiental, garantia dos direitos humanos e respeito às leis trabalhistas, dentre outros.

De acordo com o entendimento de Teixeira (2013), como a licitação é um instrumento da administração pública para garantir a seleção da proposta mais vantajosa, seria desnecessário qualificá-la como sustentável para garantir o cumprimento do tripé da sustentabilidade, (econômico, social e ambiental). Porém, como na prática, raras vezes se 
observava a inclusão desses critérios, foi preciso normatizar as CPS para se fazerem presentes nas licitações públicas brasileiras.

Em 2010, a preocupação com a qualidade ambiental, os acordos em que o Brasil é signatário, a busca pela melhora dos gastos públicos e ainda a pressão da economia externa, culminou na edição da Instrução Normativa $n^{0}$ 01/2010 do Ministério do Planejamento Orçamento e Gestão e na promulgação da Lei 12.349/2010.

Essas normativas trouxeram as contratações públicas sustentáveis como contribuição ao desenvolvimento nacional sustentável alterando a Lei de Licitações, principalmente o artigo $3^{\circ}$, com o acréscimo de mais um objetivo a ser alcançado pelo certame, o do desenvolvimento nacional sustentável.

Para cumprimento desse novo objetivo, a prática da adoção de critérios sustentáveis nas contratações de bens e serviços para administração pública passou então a ser observado e consultado nos anexos que tratam da gestão ambiental e das licitações sustentáveis, constantes no relatório de gestão anual, exigidos pelos órgãos de controle. Relatório este, em que os entes governamentais têm a obrigação de apresentar ao fim de cada exercício financeiro a fim de serem apreciadas suas contas (COSTA, 2012).

Segundo Santos e Barki (2011), uma licitação é sustentável desde o planejamento, envolvendo tanto os bens e serviços a serem contratados como a sua execução, atentando para a legislação ambiental inserida e a devida fiscalização de contrato até a destinação final dos resíduos que porventura possam advir desta contratação.

Ademais, Santiago (2009) complementa considerando que licitação sustentável é o procedimento que permite a introdução de critérios ambientais, sociais e econômicos nas aquisições de bens, contratações de serviços e execução de obras, tendo por fim o desenvolvimento da sociedade em seu sentido amplo e a preservação de um meio ambiente equilibrado. 
Bittencourt (2014) enfatiza que as licitações sustentáveis são certames públicos que exigem dos compradores governamentais, adoção da ferramenta de compra como a contratação do melhor produto ou serviço pelo menor preço e, o atendimento da questão referente à obrigação constitucional do Poder Público sobre a garantia de um meio ambiente equilibrado.

Os critérios de sustentabilidade, de acordo com a Instrução Normativa $\mathrm{n}^{\mathrm{o}} 10$ de 12 de novembro de 2012, são parâmetros utilizados para avaliação e comparação de bens, materiais ou serviços em função do seu impacto ambiental, social e econômico. (BRASIL, 2012a).

O Decreto $\mathrm{n}^{\mathrm{o}} 7.746$, de 05 de junho de 2012, regulamentou o artigo $3^{\circ}$ da Lei 8.666/93, estabelecendo critérios, práticas e diretrizes gerais para a promoção do desenvolvimento nacional sustentável nas contratações realizadas pela administração pública federal e instituiu a Comissão Interministerial de Sustentabilidade na Administração Pública (CISAP). Essa comissão tem por finalidade propor a implementação de critérios, práticas e ações de logística sustentável no âmbito da administração pública federal, direta, autárquica e fundacional e das empresas estatais e dependentes.

Segundo o Decreto ${ }^{\circ}$ 7.746/2012 são diretrizes de sustentabilidade:

I.Menor impacto sobre recursos naturais como flora, fauna, ar, solo e água;

II.Preferência para materiais, tecnologias e matérias-primas de origem local;

III.Maior eficiência na utilização de recursos naturais como água e energia; IV.Maior geração de empregos, preferencialmente com mão de obra local;

V.Maior vida útil e menor custo de manutenção do bem e da obra;

VI.Uso de inovações que reduzam a pressão sobre recursos naturais; e

VII.Origem ambientalmente regular dos recursos naturais utilizados nos bens, serviços e obras (BRASIL, 2012b).

A veiculação dos critérios e práticas de sustentabilidade, de acordo com o Decreto $\mathrm{n}^{\mathrm{o}}$ 7.746/2012, deverá constar como especificação técnica do objeto ou como obrigação da contratada. Para Bittencourt (2014), esses critérios e práticas ainda poderão relacionar-se com a pessoa do licitante; às especificações do bem ou serviço; ou obrigações mantidas durante a execução do contrato. A condição é, portanto quanto à pertinência da inserção sobre o objeto contratado, sem, contudo, frustrar o caráter competitivo. 
Em consequência da adoção de critérios sustentáveis nas compras públicas, as empresas bem como as indústrias se veem na situação de adequarem à condição para ofertar produtos com as exigências solicitadas, responsabilizando-se socialmente por seguir os preceitos calcados na qualidade, produtividade e sustentabilidade ambiental. Obtendo com isso confiabilidade pelo mercado interno, respaldo para a competitividade global e ficando aptas inclusive a padrões internacionais. (FOGLIATTI et al., 2008).

Acerca do entendimento sobre a inserção dos critérios sustentáveis na compra pública e a compra mais vantajosa, Costa $(2012$, p.10) retrata que "mais vantajosa não é a proposta de menor preço, mas a que se apresente mais adequada, mais favorável, mais consentânea com o interesse da Administração".

Desde que também observadas, sem dúvida, outras condições como o prazo, o pagamento, o preço, a qualidade, o rendimento. Entende-se por interesse da administração, inclusive o cuidado, o zelo, o equilíbrio, a igualdade, a viabilidade, dentre outros fatores contidos para a sustentabilidade, ambiental, social e econômica (COSTA, 2012).

Alencastro, Silva e Lopes (2014) entendem que, na perspectiva das CPS, a obtenção do melhor valor não leva em consideração apenas o preço dos bens e serviços, pois também englobam fatores como qualidade, eficiência, proteção ambiental, garantia dos direitos humanos e respeito às leis trabalhistas.

Promovendo o uso racional dos recursos naturais e a redução dos gastos institucionais, com uma gestão adequada e sensibilização dos servidores envolvidos, isso tudo conduz, efetivamente, à construção de um modelo de cultura socioambiental no país. Porém para a efetivação dessas ações, há dificuldades atreladas a implementação das CPS. 


\title{
2.2.2 Dificuldades na Implementação das CPS
}

As compras públicas sustentáveis como mencionado anteriormente é uma ferramenta de repercussão na política nacional do desenvolvimento sustentável. Sua implementação teve origem nas metas estabelecidas na Agenda 21 Global e no Plano de Implementação ocorrido em 2007 em Johanesburgo (ALENCASTRO; SILVA; LOPES, 2014).

Barki e Gonçalves-Dias (2014) apresentam outros compromissos assumidos pelo Brasil em iniciativas que coadunam com a sustentabilidade:

\begin{abstract}
As licitações sustentáveis no Brasil estão em consonância com os compromissos assumidos internacionalmente pelo Estado Brasileiro em prol do consumo racional e sustentável, dos quais destacamos: a Declaração do Rio sobre Meio Ambiente e Desenvolvimento (Princípio 8, 1992); a Agenda 21 Global (Capítulo 4, 1992); a Declaração de Johanesburgo sobre Desenvolvimento Sustentável (parágrafo 11) e o item III do correspondente Plano de Implantação (2002); o Acordo-Quadro sobre Meio Ambiente do MERCOSUL (2001), a Decisão 26 do Conselho do Mercado Comum, aprovando a Política de Promoção e Cooperação em Produção e Consumo Sustentáveis (2007) e as Resoluções 23/2005 e 32/2010 do MERCOSUL (BARKI; GONÇALVES-DIAS, 2014, p.19).
\end{abstract}

Estudos e pesquisas evidenciam dificuldades na implementação e execução das CPS, que podem ser pela complexa legislação, falta de cultura organizacional e falta de comportamentos favoráveis à temática, pelos gestores, como afirmam Couto e Coelho (2015); ou uso de conceito equivocado de sustentabilidade, que se reduz à questão ambiental em detrimento da social e corrupção crônica no setor público brasileiro, segundo Oliveira e Santos, (2015); escassez de fornecedores adequados e falta de insumos com as características que atendam ao cumprimento da gestão ambiental, como asseveram Alencastro; Silva; Lopes, (2014). Fatores esses que impedem a efetividade das compras públicas sustentáveis.

O modelo conceitual sugerido por Brammer e Walker (2011), sobre a implementação das CPS, caracteriza-se principalmente pelos fatores relacionados a custos e benefícios; disponibilidade de itens passíveis de critérios sustentáveis; familiaridade com as CPS; incentivos e pressões institucionais para a implementação. 
$\mathrm{Na}$ busca de conhecimento na literatura sobre as dificuldades na execução e implementação das CPS, foram encontrados termos análogos como desafios, barreiras, dificuldades, obstáculos e outros. Para este estudo optou-se pelo termo dificuldades na implementação das compras públicas sustentáveis.

As variáveis descritas por Korkmaz (2010, apud OLIVEIRA; SANTOS, 2015), caracterizam como limitadores ou barreiras às CPS: os hábitos e a dificuldade de mudança comportamental dos atores; escassez de fornecedores com o perfil; complexidade de avaliar o custo em relação ao benefício; dificuldades de incluir fatores além dos ambientais; percepção de que o processo e os resultados são mais dispendiosos e demorados

Teixeira (2013), em sua pesquisa intitulada Desafios e Oportunidades para a Inserção do Tripé da Sustentabilidade nas Contratações Públicas: um estudo de caso do Governo Federal Brasileiro e do Governo do Estado de São Paulo, concluiu que, os principais desafios relacionam-se ao receio de infringir questões legais; dificuldade de materializar critérios socioeconômicos e definir produtos e serviços sustentáveis; falta de capacitação e articulação de políticas e ainda capacidade institucional limitada.

Cogo (2015) apresentou algumas das principais barreiras do lado oferta, como custos financeiros, investimentos verdes, retorno do investimento, o preço do produto, comprometimento da alta direção, a cultura organizacional das empresas dos fornecedores, capacidade de produção, recursos humanos, configuração da cadeia de suprimentos, a localização e o tamanho de fornecedores.

Quanto aos desafios dos gestores, está em ponderar entre a elevada preocupação com a corrupção, um sistema jurídico burocrático e as interpretações restritivas das leis correlatas às compras em geral. O que contribui para o cumprimento de um rito já estabelecido em relação às compras públicas, mesmo após a publicação da Instrução Normativa 1/2010. 
Cogo (2015) destacou que, como a sustentabilidade está intimamente ligada à gestão da mudança e que a transformação de um sistema de compras tradicional para um sustentável envolve atitudes transformadoras, o não reconhecimento de modelos de gestão de mudança pode ser um dos maiores impedimentos para a implementação bem sucedida.

Assim, o real avanço depende do nível de conhecimento dos executores quanto às regras que regem o sistema, portanto, apontando para outra dificuldade, o conhecimento e familiaridade dos envolvidos nos processos das CPS (COGO, 2015).

Desse modo, considera que os aspectos jurídicos, a ausência de metas e a falta de conhecimento dos gestores tornam lenta a aplicação prática das compras públicas sustentáveis no Brasil. Conclui que, falta comprometimento político, bem como ferramentas práticas de informações e treinamento e necessidade de mudança na cultura organizacional (COGO, 2015).

Para Viegas e Cabral (2015), no âmbito das IES brasileiras, estudos mostram que há evidências da incorporação da sustentabilidade no campo, do ensino, da pesquisa e da extensão, bem como nas práticas de gestão mais rotineiras, como é o caso da coleta seletiva, do gerenciamento dos resíduos, da adequação das construções às normas e ao princípio da sustentabilidade, à arborização/paisagismo. No entanto, "a gestão das IES ainda carece de aperfeiçoamento ou inovação, além de conscientização por parte dos gestores e técnicos quanto a compras sustentáveis” (VIEGAS; CABRAL, 2015, p.256).

Teixeira (2013), também tendo como suporte o estudo de Brammer e Walker (2011), apresenta cinco grupos de fatores que influenciam a prática das CPS: informativos; financeiros; organizacionais; de disponibilidade de mercado e legalidade das CPS.

Os informativos estão relacionados ao conhecimento e familiaridade às CPS, como por exemplo, o conceito das CPS, a legislação correlata, não somente ligada às compras, mas também as que envolvem caráter ambiental e social, entender os critérios passíveis de serem 
inseridos, bem como quais materiais e serviços, além de saber identificar os termos utilizados. Onde e como buscar informações.

Segundo Tarapanoff (2001, p.36), “a informação constitui a principal matéria-prima, um insumo comparável à energia que alimenta um sistema; o conhecimento é utilizado na agregação de valor a produtos e serviços [...]". Trazendo essa linha de pensamento para este estudo, possivelmente dotando os atores envolvidos nos processos de compras do IFRO, de informações e familiaridade com o problema em questão, a busca por soluções fica mais próxima, haja vista inclusive a participação de todos com um fim comum, o de contribuir para a quebra de paradigma.

O conhecimento pode ser considerado "uma coleção de informação, uma ação ou um potencial. A questão da aquisição do conhecimento está centrada no questionamento, no processo de busca, na experimentação" (CHURCHMAN, 1971 apud TARAPANOFF, 2001, p.37).

A quebra de paradigmas ocorre quando iniciam novos ciclos científicos, econômicos e tecnológicos que afetam e provocam mudanças sociais, comportamentais e culturais nas pessoas e nas organizações (TARAPANOFF, 2001).

Os aspectos financeiros conforme Brammer e Walker (2011), é outra dificuldade, pois a percepção pelos atores de que os métodos de produção ambiental e/ou social responsáveis são mais caros que os tradicionais, cria-se uma barreira. Porém uma das principais mudanças de paradigma é analisar a diferença entre o preço imediato, valor no momento da compra, e o custo do produto na visão de longo prazo.

Essa análise pode ocorrer no custo do ciclo de vida desse produto, comparações com possíveis manutenções, eficiência na utilização de outros recursos para o funcionamento; enfim, são as análises dos gastos que serão realizados durante o uso e disposição final que devem ser levados em consideração (TEIXEIRA, 2013). 
Nos aspectos organizacionais, Teixeira, (2013) em sua pesquisa, afirma que as organizações do setor público podem apresentar culturas altamente resistentes à mudança na realização de CPS e, desta forma, a cultura organizacional pode contribuir para consequências adversas na implementação das CPS.

Em relação à resistência à mudança, Cogo (2015) afirma que mudanças normalmente falham devido às limitações de orçamento, falta de comprometimento, falta de acompanhamento, falta de comunicação e alinhamento estratégico para a iniciativa de mudança, falta de senso de urgência, falta de engajamento das partes interessadas e competências de gestão de projeto.

"Pesquisadores argumentam que qualquer mudança tem alto potencial para fracassar se os empregados não estiverem abertos para a mudança ou se eles acreditam que a mudança não será bem sucedida" (SEIJTS; ROBERT, 2011 apud MARQUES et al., 2014, p.164), portanto investir em comunicação, treinamento e acompanhamento da mudança propriamente dita, contribui para a efetividade do processo.

Quanto ao fator de dificuldade inerente à disponibilidade de produtos sustentáveis no mercado, Teixeira (2013), mais uma vez pautada em Brammer e Walker (2011), afirma que, devido às especificidades dos bens e serviços adquiridos pelo poder público, a identificação de fontes sustentáveis de fornecimento, em alguns contextos, pode ser muito desafiadora, contudo cabe à administração pública lançar gradativamente sinais de suas necessidades.

O último aspecto elencado por Teixeira (2013) foi quanto aos legais, que citando Betiol et al. (2012) afirma que o Estado, por meio de suas contratações busca corrigir ineficiências do mercado e satisfazer as necessidades coletivas dos cidadãos e que, além disso, ao realizar suas compras, o poder público deve atender às determinações legais constituídas no ordenamento jurídico. 
Assim como Teixeira (2013) e com base nas referências apresentadas nesta seção, o processo de implementação das CPS não é simples e depende de vários fatores, porém identificando os fatores específicos da Instituição e estudando-os, possivelmente podem ser apontadas soluções com a finalidade de oferecer ferramentas necessárias ao desempenho das CPS no IFRO.

\subsection{Ações que Proporcionam a Sustentabilidade nas Compras Públicas}

Dentre as ações que propiciam a promoção do desenvolvimento sustentável, tem-se a cultura organizacional direcionada à cultura de sustentabilidade, a predisposição e o envolvimento dos atores nos processos de compras, as compras compartilhadas, o benefício às microempresas e empresas de pequeno porte e a compra de produtos advindos da agricultura familiar.

\subsubsection{Cultura Organizacional e de Sustentabilidade}

O termo cultura organizacional apareceu como sinônimo de clima (organizacional) em 1960, contudo foi somente a partir de 1982 que ganhou popularidade com a publicação do livro de Terrence Deal e Allan Kennedy, (PIRES; MACÊDO, 2006).

Não há como discutir cultura organizacional sem mencionar as considerações distintas por Schein e Hofstede. Pires e Macêdo (2006) abordaram essa distinção de entendimento, enquanto que Schein entende a cultura organizacional como resultado da dinâmica de uma determinada organização; Hofstede considera como o resultado, a dinâmica cultural da sociedade na qual a organização se insere.

Lavorato (2013, p.45), concorda com a posição de Hofstede, quando destaca "que o ambiente exerce um papel fundamental sobre as mudanças culturais, embora não únicos: os 
homens mudam sua maneira de encarar o mundo por contingências ambientais quanto por transformações da consciência social”".

Na definição de Schein, a cultura é um padrão de suposições e experiências que já funcionaram anteriormente, e portanto, aptas a serem ensinadas aos novos membros do grupo. Decorre de uma cultura de um grupo que reflete o que o grupo aprendeu pela resolução dos problemas particulares durante a sua própria história. Assim, a cultura é propriedade de um determinado grupo humano e esses grupos ou organizações precisam lidar com dois tipos fundamentais de assuntos: à adaptação externa e à integração interna, nos níveis comportamental, cognitivo e emocional (PIRES; MACÊDO, 2006).

O entendimento, sob o ponto de vista de Pires e Macêdo (2006) nesse estudo, é que, de certo modo, a definição de Schein é limitada, pois não considera o contexto global no qual o grupo ou a organização estão inseridos. Já Hofstede é mais abrangente, pois considera aspectos da sociedade na organização, afirmando que não é possível compreender a cultura de uma organização sem conhecer o contexto em que se encontra. "Todo ser humano é de fato socializado de determinado meio, não se pode tornar inteligível a dinâmica humana nas organizações sem conhecer a cultura e a sociedade na qual ela se insere" (HOFSTEDE, 1994, p.180 apud PIRES; MACÊDO, 2006, p.91).

Sob o ponto de vista de Cury (2006), a cultura organizacional compreende um conjunto de propriedades do ambiente de trabalho, percebida pelos empregados, como normas formais e não formais, valores, recompensas e poder que, estão intrínsecos e atuam como um conjunto de pressupostos psicossociais que influenciam e condicionam o comportamento individual e coletivo dentro da organização.

Egeberg (2010), sob uma perspectiva organizacional, define que essas estruturas normativas, composta de regras e definições, podem ser claras ou não sobre os papeis que se esperam e como sejam feitos, são chamadas de estrutura organizacional. Além da estrutura 
organizacional, Egeberg (2010), apresenta mais três principais variáveis organizacionais, a demografia organizacional, locus organizacional, que se traduz na localização em que se encontra a estrutura física da organização e a institucionalização.

No ponto de vista organizacional, todas as instituições são organizações, porém nem todas as organizações são instituições, pois a institucionalização é uma dimensão atribuída com características de identidade, e leva tempo, portanto, classificar todos os tipos de regras, regimes e organizações como fenômenos institucionais causa um reducionismo ao conceito de institucionalização. (EGEBERG, 2010).

De acordo com Cury (2006), as normas entendidas como padrões ou regras de conduta podem ser explícitas, por meio de manuais, estatutos, regulamentos, resoluções e outros, em que as pessoas têm meios concretos para se conscientizarem; e implícitas, como as regras de conduta não identificadas formalmente, porém, nas implícitas, as pessoas se conformam, mesmo que sem uma consciência, pois essas normas estão mais atuantes na condição de governarem o comportamento dos indivíduos.

Quanto maior for a conformidade entre as normas apresentadas, portanto mais explícitas, consequentemente mais desenvolvida e eficaz será a organização, pois assim os participantes disporão de um meio eficiente e mais informativo e podem se engajar inclusive na tomada de decisões devido a um conhecimento comum (CURY, 2006).

Segundo Cury (2006), os valores apontam o que a força de trabalho julga como positivo ou negativo, indicando inclusive que há uma inter-relação com as normas, já que os valores podem estar refletidos nas normas. E uma vez que há avaliação, fica também o pressuposto que a norma pode ser avaliada como boa ou ruim.

Em se tratando das recompensas, as ciências do comportamento acreditam que é indispensável aos funcionários a recompensa ao esforço, pois as pessoas se comportam em 
função daquilo que recebem. Essa recompensa estimula os menos comprometidos e com menor rendimento, para melhorar o desempenho do trabalho, haja vista que se houver somente normas punitivas, não motivarão seus funcionários (CURY, 2006).

E por último é o poder, que deve ser identificado com a questão: quem tem o poder na organização. O prof. Bilhim (2013) menciona que, em organizações complexas e com marcada estratificação sociais, os grupos se apresentam em diferentes culturas e com isso são baseados os seus jogos e estratégias de poder e influência, como exemplo dessas organizações o professor cita os organismos públicos.

E ressalta que o "poder está presente em toda instância do quotidiano e atinge todo o tipo de interações sociais, do mais simples ao mais complexo, e que as relações de poder assentam no instrumental de competências profissionais e no capital intelectual dos grupos sócio profissionais.” (BILHIM, 2013, p.211-212)

Numa perspectiva mais aprofundada de poder, Bilhim (2002) contempla Weber e Durkhein, e aponta que, desde o trabalho pioneiro de Weber, o conceito de poder tem sido de grande importância para a compreensão e explicação da estrutura e processos organizacionais. Enquanto que Durkhein encarou o poder como o mediador de conflitos, Weber salientou as diferentes e competitivas fontes de lutas de poder dentro das organizações.

Bilhim (2002) esclarece que o entendimento de Weber e Durkhein são distintos. Na visão funcionalista de Durkhein, o poder é um mecanismo institucional de regulação, e Weber afirma que o poder destina a moldar as estruturas de dominação nas quais os atores se encontram implicados.

O poder consiste na capacidade efetiva de um indivíduo influenciar o comportamento do outro, ou seja, de induzir o outro a cumprir seus direcionamentos ou normas que o detentor 
do poder defende ou acredita. Sob este aspecto, Bilhim (2002) apresenta que há quem exponha três tipos de poder:

i. Coercivo, é que envolve a aplicação de sanções ou ameaças físicas;

ii. Remunerativo, que controla sobre os incentivos e as recompensas; e

iii. Normativo que deriva da estima ou prestígio da pessoa.

Cumpre ainda mencionar outra forma de poder citada por Bilhim (2002), quando aos indivíduos que, mesmo sem uma designação formal para o exercício de determinado cargo ou função de poder dentro da organização, exercem poder de influência por outros fatores, como carisma, informações e comunicação, peculiares de cada indivíduo.

Para Bilhim (2013), a cultura é intangível, implícita e, com seus pressupostos de compreensão e regras, direcionam o comportamento no local de trabalho de seus empregados, inclusive sendo objeto de avaliação aos novos empregados, condicionando o aceite como membros plenos da organização, se aprender tais regras.

A cultura é ponto-chave na compreensão das ações humanas, funcionando como um padrão coletivo que identifica os grupos, suas maneiras de perceber, pensar, sentir e agir. “Assim, mais do que um conjunto de regras, de hábitos e de artefatos, cultura significa construção de significados partilhados pelo conjunto de pessoas pertencentes a um mesmo grupo social". (PIRES; MACÊDO, 2006, p.83).

Pires e Macêdo (2006), sob a ótica de Mintzberg, declaram que a cultura organizacional é a base da organização, pois são as crenças comuns que se refletem nas tradições e nos hábitos, bem como em manifestações mais tangíveis, como histórias, símbolos, ou mesmo edifícios e produtos. Todavia a força de uma cultura está em legitimar as crenças e os valores compartilhados entre os membros de uma organização. Bilhim (2013, 
p.212) complementa que "toda organização sem uma cultura que permita aos seus membros uma interpretação comum do que seja ou não adequado fazer, não sobrevive e desintegra-se."

A cultura organizacional não existiria sem as pessoas, pois as organizações estão inseridas dentro de um ambiente e se interagindo, portanto, influenciando-se entre si. E é nesse ambiente de interação que as pessoas da organização atuam como agentes que contribuem constantemente com seus valores para a formação da cultura organizacional (PIRES; MACÊDO, 2006).

Isso porque os conflitos de interesse e os jogos de poder identificam os traços de cada cultura interior, e de acordo com Bilhim (2013), é indispensável à sobrevivência e condição da eficiência, pois compara a um cimento integrador de toda a organização, sendo um produto da ação e intervenção dos líderes formais e informais para uma coesão organizacional.

Nessa análise desenvolvida, pode se concluir que o gestor ou dirigente de um organismo público controla e é controlado, simultaneamente pela cultura. Quando surgem os conflitos, parece haver consciência meio generalizada, quanto a recorrer à negociação e ao recurso à hierarquia pelos líderes formais, pois quando aparecem os problemas e dificuldades é a eles que são atribuídas as responsabilidades (BILHIM, 2013). Daí se dá a importância do gestor e dirigente estarem em consonância com a cultura da organização.

Essas definições, abordagens, bem como a apresentação de conceitos e fatores atrelados à cultura organizacional tiveram a pretensão de provocar e perceber a relevância e a evidência da cultura organizacional na identificação da cultura da sustentabilidade na Instituição que está sendo pesquisada.

De acordo com Lavorato (2013), o pilar cultural será o fio condutor do processo de construção de um futuro menos impactante e insustentável com a transformação social, ao lado dos fundamentos tradicionais já conhecidos como o ambiental, o econômico e o social. 
Servirá, portanto de ferramenta para firmar os princípios e diretrizes da sustentabilidade, necessárias para nortear as escolhas, pois quanto mais indivíduos e organizações forem atingidos pelas práticas de sustentabilidade, mais rápida será a transformação de realidades dos ambientes desestruturados e excludentes; em ambientes responsáveis.

Esses princípios e diretrizes são fundamentados em valores que são inerentes aos aspectos culturais de cada indivíduo ou empresa. "É preciso construir uma cultura de sustentabilidade junto às pessoas, tanto físicas como jurídicas, de forma que as mesmas possam compreender e valorizar as escolhas, iniciativas e serviços desenvolvidos sob tais princípios” (LAVORATO, 2013, p.41).

Nesse entendimento sobre comportamento Rosini et al. (2015) também destacam que: A manutenção das condições naturais adequadas para a sobrevivência do planeta e
seus ecossistemas ativos é direta e proporcionalmente relacionada ao tipo de
comportamento adotado pelo homem. Um comportamento regrado no respeito
permitirá a relação simbiótica duradoura e saudável para ambas as partes, ao passo
que o comportamento predatório e agressivo leva incondicionalmente à falência de
um dos sistemas e, consequentemente dos demais. (ROSINI et al. 2015, p.3)

Para a consecução de uma cultura de sustentabilidade, a ciência e a tecnologia contribuem como grandes aliadas, no entanto sem investimentos em pesquisa, desenvolvimento e em educação, dificilmente terá avanços. Nada acontecerá sem uma cultura que incorpore em seus valores a sustentabilidade em todas as dimensões (LAVORATO, 2013).

Freitas (2007 apud VIEGAS; CABRAL, 2015, p.245) considera que a "cultura organizacional orientará os objetivos da missão da organização, os valores a serem seguidos nos processos de tomada de decisão”. Porém, para a internalização da sustentabilidade na cultura organizacional, é necessário que os atores sejam sustentáveis, antes de tudo, o que quer dizer que devem ser observadas as práticas sustentáveis no comportamento das pessoas e das organizações, em todas as atividades, bem como nas relações e interações (SILVA; LIMA, 2011). 
Mendonça et al. (2012), afirmam que questões de natureza ambiental têm exigido cada vez mais participação vigorosa do Estado regulador, como se observa em todos os países em que o desenvolvimento sustentável tem tido êxito. Barbieri (2004, apud MENDONÇA et al. 2012) afirma, todavia, que a participação vigorosa do Estado na gestão ambiental não garante que as questões ambientais serão tratadas corretamente pela sociedade, pois a eficácia de uma política pública ambiental depende do grau de importância que a sociedade atribui às questões ambientais.

Neste contexto, o Poder Público dispõe de uma série de instrumentos para a execução de sua gestão ambiental: de conscientização social, de comando e controle; e econômicos. Estudos direcionados à sustentabilidade enfatizam a cultura organizacional em suas abordagens como entendimento da transformação necessária para uma conscientização na busca pela sustentabilidade, a fim de se incutir primeiramente individual e consequentemente coletiva essa cultura dentre os atores inseridos no cenário.

\subsubsection{Atores envolvidos nas CPS}

Com o passar do tempo os processos de compras se tornaram mais complexos e dependentes dos atores comprometidos e conscientes do seu papel. Como a gestão de suprimentos se caracteriza como uma das principais estruturas de toda Instituição Pública, é imperativo que todos estejam imbuídos e engajados na melhoria do sistema, com a finalidade de aumentar e melhorar os resultados esperados (BATISTA E MALDONADO 2008).

Segundo os autores, apesar dos mesmos objetivos entre a compra pública e a privada na busca pelo menor preço e maior qualidade na aquisição de produtos e serviços; a compra pública se distingue principalmente pelo cumprimento da legislação criteriosa e rígida e pela determinação no cumprimento dos princípios que regem a Administração Pública. 
Nas compras públicas sustentáveis, todos os servidores têm sua parcela de importância dentro da política de sustentabilidade, tanto os da alta administração, como os responsáveis pela solicitação dos materiais, serviços e obras, ou os que executam, licitam e fiscalizam como ainda os fornecedores dos insumos e serviços. Todos são considerados atores envolvidos numa espécie de mosaico que, de acordo com as atribuições peculiares a cada um, contribui na conduta dessas compras.

Todavia, alguns se destacam em detrimento a outros, seja pela posição hierárquica, pela influência que exerce ou pelas características de suas atividades. Um caso de destaque são os servidores solicitantes de materiais e serviços, geralmente desempenhados pelos que estão lotados nos setores de almoxarifado e patrimônio, serviços gerais e coordenação de contratos, pois são responsáveis pelo recebimento e organização dos pedidos.

Outros que se destacam são os servidores ligados às áreas de planejamento, pela posição que cabe na tomada de decisão e na responsabilidade assumida perante aos órgãos de controle, inclusive respondendo solidariamente com o ordenador de despesa. Trazendo à tona a discussão sobre o consumidor, já que o servidor na condição de comprador se coloca nessa posição, é pertinente conhecer o que influencia as compras.

Ottman (1994, apud FIGUEIREDO; ABREU; CASAS, 2009) defende que são os valores morais que influenciam a decisão de compra das pessoas quando decidem adquirir produtos ecologicamente corretos em detrimento dos convencionais, pois, ao tentarem se proteger e protegerem o planeta, acabam por moldar uma tendência e o consumismo próambiental. Segundo o mesmo autor, o conceito de consumidor verde ou ecologicamente consciente é o que busca consumir produtos que minimizem prejuízos ao meio ambiente

Couto e Coelho (2015), no estudo que abordou os fatores críticos no comportamento do gestor público responsável por compras sustentáveis, analisaram o comportamento individual e organizacional, quanto às compras. Segundo os autores, quando o gestor público 
define critérios e especificações dos bens e serviços a ser adquiridos em uma compra, sua atuação é de um consumidor organizacional.

O foco principal dessa pesquisa foi a parte III do questionário, o qual apresentou 50 afirmações, divididas em dois módulos com 25 questões cada, sendo um versando sobre o comportamento referentes às compras individuais e o outro módulo versando sobre o comportamento referentes às compras organizacionais. As afirmações de um módulo eram correlatas ao outro, ou seja, a única diferença era somente quanto ao contexto.

Buscou-se avaliar as possíveis discrepâncias do comportamento do servidor quando submetido a diferentes contextos de compras e práticas ambientais, comparando as respostas no contexto de compra individual e de compra organizacional.

Os resultados obtidos foram que os padrões de respostas para a maioria das afirmações apresentadas aos participantes não diferiram significativamente entre os dois contextos. Diante dos resultados, a leitura feita pelos autores foi que, em referência aos padrões ambientais que tem por consequência comum a diminuição do gasto, as respostas foram semelhantes nos dois contextos. Contudo, o entendimento relacionado à escolha do menor preço, tempo gasto na descrição e fator relacionado a marca, são cuidadosamente mais rigorosos e atendidos no contexto organizacional, já que são regidos por leis restritivas e exigentes.

O que se pode tirar desse estudo, como parâmetro, é que o fator comportamento varia pouco de um contexto para o outro, porém pode ser constatado que, sob a condição de normativas estabelecidas, o cumprimento e o comprometimento do servidor sobressaem no contexto organizacional. Sendo assim, supõe-se que a conscientização e a informação clara e disseminada é condição essencial no auxílio da tomada de decisão dos atores envolvidos, assim como primordial as determinações de normativas direcionadas em favor da sustentabilidade. 
No âmbito de cada órgão ou entidade, a responsabilidade pelas compras e contratações é das unidades administrativas setoriais de serviços gerais, geralmente subordinadas a um gestor, responsável por todas as funções administrativas. (COSTIN, 2010).

Para isso, segundo Bittencourt (2014, p.29), a respeito da responsabilidade do servidor público, deixa claro que "na avaliação do critério de sustentabilidade, o agente público deverá conhecer as diretrizes do desenvolvimento sustentável, contidos no Decreto regulamentar 7.746/2012”, ora apresentado anteriormente na Seção 2.2 Compras Públicas Sustentáveis.

Um comprador público deve levar em consideração, em sua decisão, as sugestões e opiniões dos requisitantes no intuito de estar constantemente aprimorando aspectos técnicos que envolvem as compras, portanto é imprescindível a necessidade da participação e comprometimento de todos os envolvidos, pois especificação completa, clara e concisa promove uma compra eficaz e adequada e, consequentemente, alinhada aos princípios da licitação (BATISTA; MALDONADO, 2008).

Cogo (2015) destaca a importância dos gestores públicos dentro de cada atividade do processo de compra, visto que a Administração Pública Federal é representada por estes agentes, desse modo, sua conscientização é imprescindível para atender plenamente aos objetivos dispostos, pois são eles os atores responsáveis pela mudança nos processos através do seu poder na tomada de decisão.

Oliveira e Santos (2015) também ressaltam a responsabilidade do gestor público encarregado de definir as regras do jogo a fim de assegurar a livre concorrência sem incorrer na falta de compromisso em proporcionar a melhor aquisição com o menor preço possível.

Tamanha é a atribuição dos agentes que desempenham discricionariamente a escolha de bens, serviços ou obras com critérios sustentáveis, sem a disponibilidade de ferramentas objetivas suficientes que garantam à obtenção da compra ou contratação mais vantajosa, pois mesmo com o estabelecimento das diretrizes para atuação na adoção de critérios de 
sustentabilidade, amparada pela $\mathrm{IN} \mathrm{n}^{\circ}$ 01/2010, ainda há incerteza na aplicação (COUTO; COELHO, 2015).

Batista e Maldonado (2008) deixam claro que a atividade de compra implementa o trabalho dos outros departamentos, pela aquisição de insumos necessários para a realização dos trabalhos finalísticos da Instituição e Gazzoni et al (2015, p.12) destacam que "a busca pelo desenvolvimento sustentável deve ser uma política de âmbito institucional, mas desenvolvida em nível operacional”.

Considerando a pouca incidência e a dificuldade apontada em estudos sobre inserir critérios com cunho social nas CPS, serão apresentadas algumas ações que vão ao encontro das contribuições e minimizam os efeitos da dificuldade em se contratar e adquirir produtos e serviços sustentáveis, como a adoção das compras compartilhadas, o atendimento quanto ao benefício as micro e pequenas empresas (MPEs) e as compras de gêneros alimentícios advindos da agricultura familiar.

\subsubsection{Compras Compartilhadas}

Conforme a Instrução Normativa $\mathrm{n}^{\mathrm{o}} 10$ de 12 de novembro de 2012, uma das novidades, dentre as práticas de sustentabilidade, é o incentivo às compras compartilhadas, que se fundamenta na contratação para um grupo de participantes previamente estabelecidos, em que a responsabilidade de condução do processo licitatório e o gerenciamento da ata de registro de preços cabem a um órgão ou entidade da administração pública federal (BRASIL, 2012a).

A compra compartilhada é regulamentada pelo Decreto $\mathrm{n}^{\circ} 7.892$, de 23 de janeiro de 2013, que trata do Sistema de Registro de Preços (SRP) previsto no artigo 15 da Lei ${ }^{\circ}$ 8.666/93. O SRP é o conjunto de procedimentos para registro de preços relativos à prestação de serviços e aquisição de bens para contratações futuras, devidamente formalizadas por um 
instrumento vinculativo, obrigatório, com característica de compromisso para futura contratação. Nele se registram os preços, fornecedores, órgãos participantes e condições praticadas, conforme as disposições contidas no instrumento convocatório e propostas apresentadas (BRASIL, 2013b).

O SRP geralmente é adotado para atender as hipóteses de: quando pelas características do bem ou serviço, houver necessidade de contratações frequentes; quando for conveniente a aquisição de bens com previsão de entregas parceladas ou contratação de serviços remunerados por unidade de medida ou em regime de tarefa; quando for conveniente a aquisição de bens ou a contratação de serviços para atendimento a mais de um órgão ou entidade, ou a programas de governo; ou quando pela natureza do objeto, não for possível definir previamente o quantitativo a ser demandado pela administração.

Esse órgão responsável recebe a denominação de órgão gerenciador, pois sua atribuição é justamente realizar com o auxílio dos órgãos participantes, todo o procedimento licitatório, como registrar no portal de compras do governo federal a intenção de registro de preços, bem como consolidar informações relativas à estimativa individual e total contempladas nos termos de referência ou projetos básicos, dentre outros procedimentos atrelados aos processos de compras e contratações.

Já os órgãos participantes, como são chamados, são os interessados em participar da licitação promovida pelo órgão gerenciador, mediante a utilização da Intenção de Registro de Preços, precedendo ao início dos trabalhos licitatórios. O órgão participante manifestará interesse na licitação, providenciando o encaminhamento de sua estimativa de consumo, local e cronograma de entrega, desde que devidamente autorizada pela autoridade máxima a que pertence.

As modalidades de licitação que contemplam o SRP são concorrência, regida pela Lei 8.666/1993 e o pregão pela Lei 10.520/2002. Esse tipo de processo visa proporcionar 
agilidade nas licitações e ampliação do número de órgãos beneficiados com a mesma licitação, inclusive estabelecendo uma linha de preço mais vantajosa em razão do montante a ser licitado.

Essa prática é defendida por Bittencourt (2014), já que a adoção das licitações compartilhadas consigna uma solução sobre o problema do não alcance de alguns produtos sustentáveis da economia de escala necessária para possuírem preços competitivos.

Para Teixeira (2013), a utilização das compras compartilhadas contribui na disseminação das CPS, no aproveitamento do potencial de outras instituições servindo como multiplicadoras de práticas relacionadas à inserção de critérios socioambientais e para a redução dos preços dos produtos por meio da economia de escala, já que o fator preço é considerado um dos grandes entraves à efetivação das compras públicas sustentáveis.

Em 2010, a contratação direta, por meio da dispensa de licitação foi a modalidade que mais representou às CPS, um total de 1.138 compras, seguida do pregão eletrônico, com 661 . Porém houve redução gradativa no período de 2010 a 2014, passando para 405 compras. Em contrapartida houve um aumento ao pregão eletrônico, atingindo 840 compras nesse mesmo ano, o equivalente a 67 por cento das aquisições (MPOG, 2014)

A abrangência do pregão eletrônico nas CPS, proporcionada pela a utilização do SRP, atende um número considerável de organizações, haja vista que dispõe da praticidade da inclusão dos órgãos participantes e ainda permite após a ata registrada, a sua adesão, mais comumente chamada de carona. O que tem contribuído para as compras sustentáveis.

\subsubsection{Benefício às Micro e Pequenas Empresas - MPE}

Outra prática que visa à sustentabilidade é a exclusividade dada as MPEs nas licitações, pelo cumprimento da Lei $\mathrm{n}^{\mathrm{o}}$ 123, de 14 de dezembro de 2006, que estabelece normas gerais relativas ao tratamento diferenciado e favorecido às microempresas e empresas 
de pequeno porte (MPE), em outras palavras, tratam dos benefícios concedidos e determina o cumprimento de tratamento diferenciado a essas categorias de empresas.

Para este estudo, a apresentação da Lei 123/2006, terá ênfase no benefício relacionado à exclusividade nas compras públicas, o que proporciona oportunidade aos pequenos negócios e consequentemente contribui para o desenvolvimento nacional sustentável, objetivo este também a ser alcançado pela licitação por meio das compras e contratações públicas.

Com o crescimento da demanda por bens e serviços do Estado, as compras públicas passaram a não ser apenas percebidas como um meio para o suprimento de bens necessários ao funcionamento da Administração Pública, mas inclusive como um instrumento de geração de emprego, renda e desenvolvimento local. Que tem como além de outras finalidades, a de aplicar recursos públicos no intuito de fomentar grupos ou segmentos da sociedade considerados vulneráveis ou estratégicos para a economia nacional (BRASIL, 2013a).

No Brasil, segundo Costin (2010, p.199), “a legislação garante incipiente preferência à participação dessas empresas no processo de compras públicas, pois são reduzidos os instrumentos legais que regulamentam a concorrência no mercado de compras governamentais, sobretudo a discrepância econômica entre as grandes e empresas de pequeno porte".

Em entrevista prestada por Ana Maria Vieira dos Santos Neto, Diretora de Produção e Consumo Sustentáveis do Ministério do Meio Ambiente, em 26 de outubro de 2012, à Teixeira (2013), lê-se que, no processo de aprimoramento das contratações públicas, primeiramente o governo se dedicou às questões de economicidade e eficiência, pois se pagava muito caro pelos produtos e serviços contratados.

Explicou que, em razão dessa preocupação, houve melhorias de processos que geraram uma maior transparência e economia aos cofres públicos, principalmente devido à 
incorporação das compras eletrônicas, porém, apesar das economias financeiras pelas melhorias, ainda se paga um valor elevado na aquisição de bens e contratação de serviços na administração pública, considerados inclusive de baixa qualidade.

Em seguida, Santos Neto também destacou que foi iniciado um trabalho para desenvolver aspectos socioeconômicos nas contratações, como o tratamento diferenciado às MPEs, e acrescentou que a própria Lei de Licitações, (Lei 8.666/93), já trazia várias questões sociais, como por exemplo, a contratação de mão de obra local.

A Constituição Federal de 1988 elegeu o tratamento diferenciado e privilegiado às micro e pequenas empresas, com benefícios fiscais, trabalhistas, previdenciários e, nas compras públicas, com o objetivo do desenvolvimento econômico e promover a justiça social, pois essas categorias de empresas provocam importante impacto no contexto social (ROSSETTI, 2015).

Neste prisma, para Bittencourt (2014), a Lei Complementar 123/2006 foi o primeiro paradigma quebrado na função social da licitação, pois em contribuição à promoção de objetivos sociais e econômicos, a lei eliminou as desigualdades devidas aos estabelecimentos de regras diferenciadas para as contratações públicas, beneficiando MPE, quando instituiu o Estatuto Nacional da Microempresa e da Empresa de Pequeno Porte.

Entende-se por microempresa e empresa de pequeno porte, segundo Brasil (2006):

[...] empresário ou pessoa jurídica que aufira, em cada ano-calendário, receita bruta igual ou inferior a $\mathrm{R} \$ 360.000,00$ (trezentos e sessenta mil reais) e considera empresa de pequeno porte àquelas que empresário de pequeno porte ou pessoa jurídica que aufira, em cada ano-calendário, receita bruta superior a $\mathrm{R} \$ 360.000,00$ (trezentos e sessenta mil reais) e inferior a 3.600.000,00 (três milhões e seiscentos mil reais) (BRASIL, 2006)

O MPOG, em pesquisa publicada e divulgada pelo caderno de estudo, afirma que as microempresas e empresas de pequeno porte retratam $99 \%$ das empresas formalmente estabelecidas no Brasil, gerando mais de $52 \%$ dos empregos formais. Impacta também em 
$40 \%$ da massa salarial, $70 \%$ das novas vagas geradas por mês e contribui em $1 \%$ nas exportações (BRASIL, 2013a).

Dados semelhantes quanto à participação dessas categorias de empresas, puderam ser observados em estudo de Ferreira (2015), sobre a adoção de tecnologias pelas micro e pequenas empresas de retalho alimentar em Portugal, que onde as microempresas e empresas de pequeno porte, correspondem a $98,2 \%$ do total das empresas portuguesas.

Em Portugal, como também no Brasil, ficou evidenciada a importância que as micro e pequenas empresas desempenham no país, quanto ao grande impacto na economia, com a geração de emprego, renda e contribuição para o desenvolvimento local e regional (BRASIL, 2013a; FERREIRA, 2015).

Segundo Brasil (2013a, p.6), "em países mais desenvolvidos e com boa distribuição de renda, a participação no PIB acontece em percentual equilibrado ao das grandes empresas, onde no Brasil chega próximo ao patamar de 20\%". Sustentando a afirmação, Chrisman et al., (2003 apud FERREIRA, 2015), destacam que as MPE contribuem significativamente para o aumento do PIB e do emprego de qualquer país do mundo. Sobre a necessidade do Estado em induzir o desenvolvimento social, pelas MPEs, Silva (2015) defende:

É necessário tratar em conjunto com a geração de emprego e renda, o incentivo a
microempresas e empresas de pequeno porte, bem como a indução do
desenvolvimento local. É necessário que o Estado seja indutor de um novo
paradigma de desenvolvimento, com a nova visão de que a vantajosidade nas
licitações não deve ser apenas econômica, mas também ambiental e social,
respeitando as diferenças regionais e locais desse imenso país (SILVA, 2015, não
paginado) De acordo com a Figura 1 pode-se visualizar o fluxo da contribuição das MPE no desenvolvimento do país, com aumento das receitas, consequente geração de renda e arrecadação de impostos. 
Figura 1 - Benefício de se comprar das MPE

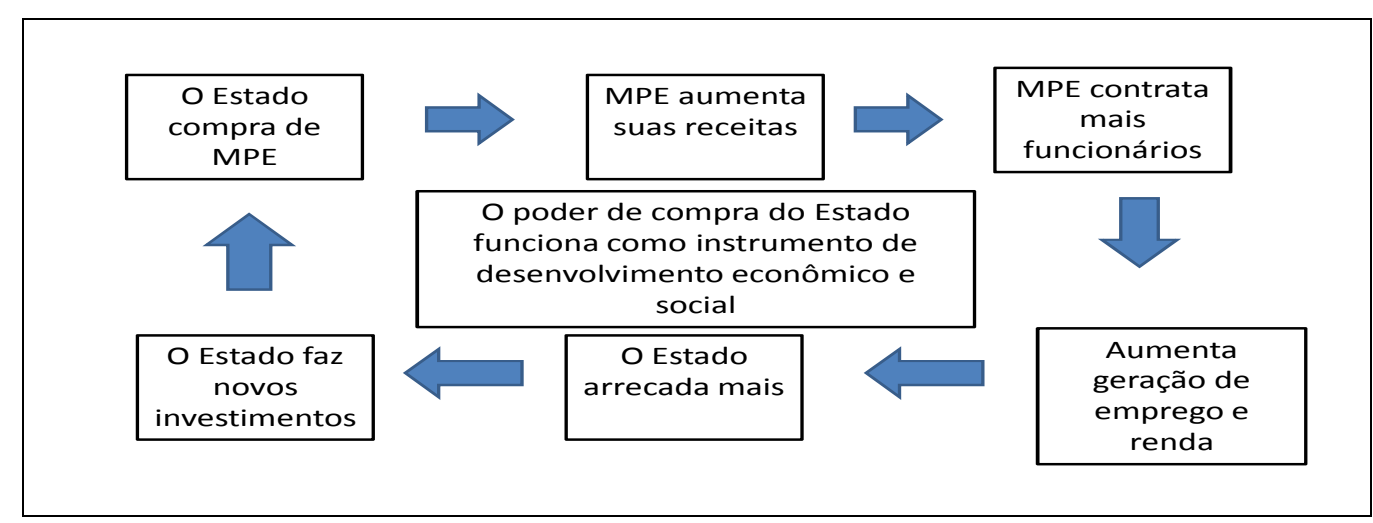

Fonte: Adaptado de Brasil (2013a)

Pode-se observar na Figura 1 que o ciclo de compras e contratações, beneficiando às MPES, tem impacto na economia local culminando no desempenho de todo país, gerando um círculo virtuoso que afeta a todos os envolvidos no processo.

A Lei 123, como é popularmente mencionada, trouxe em seu conteúdo a condição de que nas contratações públicas da União, dos Estados e dos Municípios, poderiam-se conceder tratamento diferenciado e simplificado a essas categorias de empresas, a fim de promover além do desenvolvimento econômico e social no âmbito municipal e regional, também a ampliação da eficiência das políticas públicas e o incentivo à inovação tecnológica. (TCU, 2010).

Em 2014, a Lei Complementar 147, de 07 de agosto de 2014, alterou alguns artigos, revogou e incluiu outros na Lei Complementar original, proporcionando ainda maiores benefícios às MPE, e a condição anterior que era de "poderia", passou para "deveria". O objetivo materializado pela Lei 123, de acordo com Rossetti (2015, p.145) é "propiciar condições de competitividade a essas empresas, estimular o ambiente de oferta e procura e favorecer os consumidores, neutralizando os efeitos indesejáveis de monopólios e oligopólios.

No capítulo V da Lei 123/2006, que trata do acesso aos mercados, estão dispostos os artigos 42 a 49 relacionados aos benefícios das MPEs nas aquisições públicas. O artigo 47 dispõe que, nas contratações públicas da administração direta e indireta, autárquica e 
fundacional, federal, estadual e municipal, deverá ser concedido tratamento diferenciado e simplificado para as microempresas e empresas de pequeno porte, objetivando a promoção do desenvolvimento econômico e social no âmbito municipal e regional, a ampliação da eficiência das políticas públicas e o incentivo à inovação tecnológica. E, para o seu cumprimento, segue o disposto no artigo 48 para conhecimento: (BRASIL, 2006)

I - deverá realizar processos licitatórios destinados exclusivamente à participação de microempresas e empresas de pequeno porte nos itens de contratação cujo valor seja de até $\mathrm{R} \$ 80.000,00$ (oitenta mil reais).

II - poderá, em relação aos processos licitatórios destinados à aquisição de obras e serviços, exigir dos licitantes a subcontratação de microempresa ou empresa de pequeno porte.

III - deverá estabelecer, em certames para aquisição de bens de natureza divisível, cota de até $25 \%$ (vinte e cinco por cento) do objeto para a contratação de microempresas e empresas de pequeno porte.

$\S 2^{\circ} \mathrm{Na}$ hipótese do inciso II do caput deste artigo, os empenhos e pagamentos do órgão ou entidade da administração pública poderão ser destinados diretamente às microempresas e empresas de pequeno porte subcontratadas.

$\S 3^{\circ}$ Os benefícios referidos no caput deste artigo poderão, justificadamente, estabelecer a prioridade de contratação para as microempresas e empresas de pequeno porte sediadas local ou regionalmente, até o limite de $10 \%$ (dez por cento) do melhor preço válido (BRASIL, 2006)

Para Rossetti (2015), com o Estado coordenando políticas públicas sob as mais diversas vertentes, inclusive aquelas que tangenciam o mercado beneficiando às MPE, como simplificar e reduzir obrigações fiscais, diminuir a burocracia relacionada às obrigações societárias, facilitar o acesso ao crédito, e impactando significativamente nas contratações públicas, causam, além do próprio fortalecimento, um ambiente propício ao desenvolvimento, econômico e social.

Segundo dados do portal de compras do governo, a participação de microempresa e empresa de pequeno porte nas CPS é muito presente e crescente. Desde 2010, vem mantendose acima de $80 \%$ e atingindo em 2013 e 2014 um percentual de $89 \%$. Ao todo, entre os participantes de MPE e demais categorias de empresas, em 2014 participaram de processos de contratações sustentáveis 3.563 fornecedores, perfazendo um total de 1.245 compras 
distribuídas nas modalidades de licitação, como pregão eletrônico, pregão presencial, convite e contratação direta. (MPOG, 2014).

Uma das reclamações pelos microempresários e empresários de pequeno porte em estudo de Motta e Oliveira, (2015) foi sobre a divulgação das licitações. O SEBRAE, no intuito de facilitar e auxiliar os responsáveis pelas microempresas e empresas de pequeno porte, na busca por licitações em andamento, desenvolveu um buscador que concentra em uma única pesquisa, informações em mais de 550 portais de compras públicas, pois atende as licitações publicadas pelos governos de todas as esferas, federal, estadual e municipal.

Essa busca é uma das ações do Movimento Compre do Pequeno Negócio, administrado pelo SEBRAE em prol dessas categorias de empresas. A busca pode ser realizada por área de atuação, como natureza da despesa, ou mais específica, filtrando por estado, cidade, modalidade de licitação, data e palavra chave. (PEGN, 2015).

Dando sequência a mais uma prática que pode ser aplicada às compras públicas com um cunho de sustentabilidade, está a compra de produtos da agricultura familiar.

\subsubsection{Agricultura Familiar}

De acordo com os dados do relatório publicado em outubro de 2015 pelas Nações Unidas (ONU), o programa de compras públicas da agricultura familiar é uma ferramenta de combate a fome. Segundo Raúl Benítez, representante regional da Organização das Nações Unidas para a Alimentação e Agricultura (FAO), nos últimos anos, estes programas têm passado a ser uma parte integral das políticas de segurança alimentar e nutricionais da região, já que permitem garantir o direito à alimentação, melhorar a vida dos mais vulneráveis e promover o desenvolvimento local (FAO, 2015). 
Martinelli et al. (2015, p.559) “informam que a FAO, assim como o Programa Mundial de Alimentos (PMA) e a Organização Mundial de Saúde (OMS) vêm referenciando a necessidade de desenvolvimento de políticas e programas voltados para o fortalecimento da agricultura familiar e a aproximação entre produção e consumo de alimentos".

Dentre as ações que têm como propósito buscar a criação de mercado para produtos sustentáveis e o estabelecimento de novos parâmetros para o setor privado, a Lei 11.947/2009 determina que no mínimo $30 \%$ dos recursos repassados pelo Fundo Nacional de Desenvolvimento da Educação (FNDE) para a alimentação escolar sejam destinados a compras de produtos advindos da agricultura familiar (BRASIL, 2009).

Segundo Oliveira e Santos (2015), a Lei 11.947/2009 foi um dos maiores avanços em termos de critérios sociais, pois prioriza os assentamentos de reforma agrária, as comunidades tradicionais indígenas e quilombolas, porém, a adoção desses critérios ainda é rara, e a negligência faz com que a questão social seja marginalizada.

No Brasil o Programa de Aquisição de Alimentos (PAA) e o Programa Nacional de Alimentação Escolar (PNAE) beneficiam cerca de 450 mil agricultores familiares e movimentam 700 milhões de dólares no setor, proporcionando alimentos a 65 milhões de pessoas. Atualmente, de acordo o Ministério do Desenvolvimento Social e Combate à Fome (MDS), foi criada a compra Institucional do PAA, que tem como objetivo promover o acesso da população à alimentação de qualidade e o fortalecimento da agricultura familiar. (FAO, 2015).

\footnotetext{
A magnitude da produção de base familiar para a garantia da segurança alimentar e nutricional (SAN) é evidenciada pela sua representatividade na produção de alimentos básicos, destinados ao consumo nacional e fundamentais para uma dieta saudável. Na América Latina e no Caribe, a agricultura familiar é responsável pela produção da maioria desses alimentos. No caso brasileiro, $67 \%$ do feijão, $84 \%$ da mandioca, $52 \%$ do leite e $49 \%$ do milho são provenientes desse seguimento produtivo. (MARTINELLI, et al., 2015, p.559).
} 
A fim de fortalecer o PAA, a partir de janeiro de 2016, ficou estabelecido aos órgãos e entidades da Administração Pública Federal direta, autárquica e fundacional que, do total de recursos repassados para aquisição de gêneros alimentícios, pelo menos 30\% deverão ser destinados à aquisição de produtos da agricultura familiar, ou de suas organizações ou demais beneficiários da Lei 11.326, de 24 de julho de 2006 (BRASIL, 2015).

As aquisições de alimentos poderão ser realizadas na modalidade de dispensa licitação, por meio de chamada pública, desde que atendidas, cumulativamente, as condições contidas no artigo $5^{\circ}$ do Decreto 7.775, de 04 de julho de 2012, explicitados no Quadro 1.

I. Os preços sejam compatíveis com os vigentes no mercado, em âmbito local ou regional, aferidos e definidos segundo metodologia instituída pelo GGPAA.

II. Os beneficiários e organizações fornecedores comprovem sua qualificação, na forma indicada nos incisos II e III do caput do art. $4^{\circ}$, conforme o caso.

III. Seja respeitado o valor máximo anual ou semestral para aquisições de alimentos, por unidade familiar, ou por organização da agricultura familiar, conforme o disposto no art. 19.

IV. Os alimentos adquiridos sejam de produção própria dos beneficiários fornecedores e cumpram os requisitos de controle de qualidade dispostos nas normas vigentes. (BRASIL, 2012c).

Quadro 1 - Condições para a compra de produtos da agricultura familiar

\begin{tabular}{|c|l|}
\hline Quem compra & $\begin{array}{l}\text { Quem fornece alimentação: Hospitais públicos; forças } \\
\text { armadas (Exército, Marinha e Aeronáutica); presídios; } \\
\text { restaurantes universitários; hospitais universitários; } \\
\text { refeitórios de creches e escolas filantrópicas, entre } \\
\text { outros }\end{array}$ \\
\hline Quem vende & $\begin{array}{l}\text { Agricultores familiares; assentados da reforma } \\
\text { agrária; silvicultores; aquicultores; extrativistas; } \\
\text { pescadores artesanais; comunidades indígenas; } \\
\text { comunidades quilombolas e demais povos e } \\
\text { comunidades tradicionais que possuam Declaração de } \\
\text { Aptidão ao PRONAF (DAP física); as cooperativas e } \\
\text { outras organizações que possuam DAP jurídica. }\end{array}$ \\
\hline Definição de preços & $\begin{array}{l}\text { O órgão comprador deverá realizar no mínimo três } \\
\text { pesquisas no mercado local ou regional para } \\
\text { parâmetro de preços. }\end{array}$ \\
\hline Limite de venda & $\begin{array}{l}\text { Cada família pode comercializar até R\$ 20.000,00 } \\
\text { (vinte mil reais) por ano, por órgão comprador, } \\
\text { independente dos fornecedores participarem de outras } \\
\text { modalidades do PAA e do PNAE. Para os detentores } \\
\text { de DAP jurídica, esse valor é de R\$ 6.000.000,00 (seis } \\
\text { milhões de reais) por órgão comprador, por ano. }\end{array}$ \\
\hline
\end{tabular}

Fonte: Adaptado do MDS (2016) 
Os programas de compras públicas permitem criar um vínculo virtuoso entre a agricultura familiar, os mercados locais e os programas de assistência dos governos e os consumidores, gerando benefícios a todos. O livro produzido pelo Programa de Cooperação Brasil - FAO, traz uma visão ampla das contribuições das compras públicas da agricultura familiar como uma eficiente política pública de desenvolvimento (FAO, 2015).

Os benefícios da compra de produtos da agricultura familiar, nas compras públicas, segundo a FAO (2015) são:

a) Fortalecer e garantir o direito humano à alimentação adequada;

b) Melhorar o atendimento às pessoas mais vulneráveis;

c) Contribuir na formação de hábitos alimentares saudáveis;

d) Promover o desenvolvimento local e fortalecer os circuitos curtos de comercialização;

e) Permitir a abertura de novos mercados para a agricultura familiar, proporcionando que os marcos jurídicos e normativos de compras sejam mais justos;

f) Estimular a articulação de políticas públicas;

g) Ampliar a participação social;

h) Ampliar a visibilidade da agricultura familiar na sociedade e contribuir para a diversificação da produção de alimentos;

i) Contribuir para a fixação e subsistência de pequenos agricultores no campo 


\section{METODOLOGIA}

De acordo com Zanella (2009, p.55-56), ciências administrativas, enquanto ciências sociais possuem as mesmas características, "sendo assim, ao pesquisar qualquer fato então no campo da Administração Pública, também pesquisará 'pessoas' situadas em dado momento histórico, com sua própria forma ideológica de pensar e agir e com suas crenças e valores".

E, é neste contexto que o tema desta pesquisa se propõe a alcançar o objetivo de identificar os fatores que dificultam a exequibilidade na implementação das CPS no IFRO, por meio de levantamento da percepção junto aos servidores envolvidos nas áreas de compras e licitações, gestão de contratos, orçamento e finanças e demandantes de insumos e serviços e a alta gestão, permeando desde a solicitação até a entrega do bem ou serviço.

\subsection{Tipo e descrição geral da pesquisa}

A presente pesquisa se caracteriza quanto aos fins como exploratória e de investigação descritiva. Quanto aos meios, o estudo contempla a pesquisa de campo com o estudo de caso, considerando que os dados primários foram coletados no local onde ocorre o fenômeno e dispõe de elementos para explicá-lo e que, sua característica está "circunscrita a uma ou poucas unidades, como pessoa, família, produto, empresa, órgão público, comunidade ou mesmo país.” (VERGARA, 2013; YIN, 2010).

Para Bressan (2000), o estudo de caso investiga um fenômeno contemporâneo dentro de um contexto da vida real em que múltiplas fontes de evidência são utilizadas. Também Günther (2006), destaca que, em estudo de caso, é possível utilizar tanto procedimentos qualitativos quanto quantitativos e que, ao conceber o processo de pesquisa como um mosaico, descreve um fenômeno complexo a ser compreendido.

Nesse sentido, a abordagem de investigação utilizada foi a de métodos mistos, que associa as formas qualitativas e quantitativas, tanto na coleta como no tratamento e análise 
dos dados. Para tanto, utilizou-se como instrumento de coleta de dados, o questionário, a observação participante e documentos no decorrer da pesquisa.

Considerando que todos os métodos apresentam limitações, a utilização de métodos mistos foi entendida pelos pesquisadores como um neutralizador de vieses que porventura pudessem ocorrer, já que, em uma mesma pesquisa, eram empregadas técnicas quantitativas quanto qualitativas, na coleta dos dados e, sobretudo nas análises. (CRESWELL, 2010)

Como esta técnica pode como alternativa unir os dados qualitativos e quantitativos ou os próprios resultados das duas abordagens tradicionais, numa espécie de complemento em combinação, evoluindo posteriormente, de uma convergência para uma integração, ou conexão dos dados, foi utilizado o método misto concomitante, em que o pesquisador mistura os dados quantitativos e qualitativos a fim de realizar uma análise mais ampla, coletando os dados distintos ao mesmo tempo, depois os integrando na interpretação dos resultados gerais (CRESWELL, 2010)

\subsection{Caracterização da organização}

A instituição pesquisada está localizada no Estado de Rondônia que, segundo dados do último censo, teve uma população estimada para 2015, em 1.768.204 habitantes (IBGE, 2015). O Estado está situado na Região Norte do Brasil, que, dada as suas características socioeconômicas, assemelha-se à Região Nordeste, haja vista que ambas apresentam índices relacionados à desigualdade econômica elevada, baixo crescimento econômico e índice de desenvolvimento humano abaixo da média nacional, principalmente se comparada às regiões sul e sudeste.

Rondônia, porém, apresenta características distintas se comparadas aos outros Estados da mesma região, pois dentro de uma abordagem relacionada ao desenvolvimento, foram trazidos alguns dados para conhecimento e, já que o presente trabalho discorre sobre 
sustentabilidade, será demonstrada na Tabela 1, a dimensão social, retratada pela renda, pobreza e desigualdade.

Tabela 1 - Índice de renda, pobreza e desigualdade de Rondônia

\begin{tabular}{l|r|r|r}
\multicolumn{1}{c|}{ Indicadores } & \multicolumn{2}{c}{ Período } \\
\hline & $\mathbf{1 9 9 1}$ & $\mathbf{2 0 0 0}$ & $\mathbf{2 0 1 0}$ \\
\hline Renda per capita (em R\$) & 304,90 & 467,16 & 670,82 \\
\hline$\%$ de extremamente pobres & 25,17 & 12,60 & 6,39 \\
\hline$\%$ de pobres & 48,19 & 29,81 & 14,80 \\
\hline Índice de Gini & 0,62 & 0,60 & 0,56 \\
\hline Fonte: IBGE $(2015)$ & &
\end{tabular}

Quanto ao índice de Gini, esse indicador demonstra a desigualdade da população em uma escala que varia de zero a um, equivalendo dizer que, quanto mais próximo de um, indica uma concentração maior de renda, portanto, um distanciamento entre pobres e ricos. Ao contrário, quanto mais próximo de zero, menor a desigualdade.

No período de 1976 a 2013, Rondônia se destacou dentre todos os outros estados da federação por ser considerado o Estado que mais reduziu o índice de desigualdade, seguido pelos Estados do Rio de Janeiro, Pernambuco, Amapá e Pará, como pode ser melhor visualizado no Figura 2.

Figura 2 - Evolução do coeficiente de Gini no período de 1976 a 2013 entre os Estados brasileiros

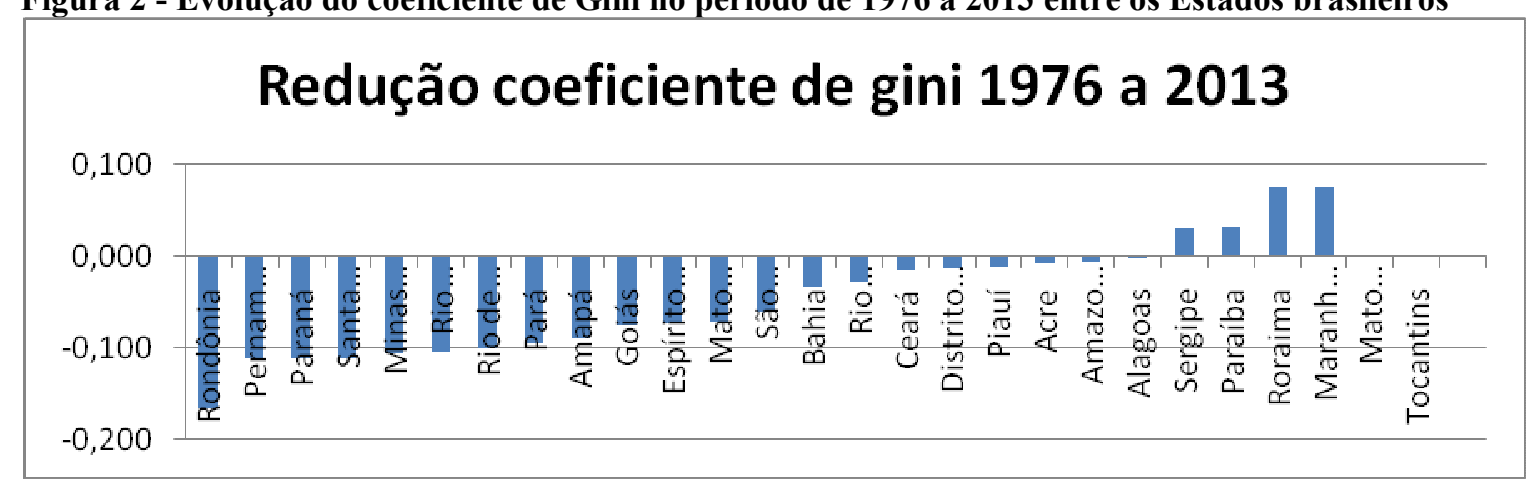

Fonte: Ipeadata/2015

Na Região Norte, Rondônia é o terceiro mais populoso, tendo como maior densidade demográfica apenas os Estados do Pará e Amazonas. Tem o maior PIB Per capita da região e o $12^{\circ}$ do país. Sua principal atividade é a agricultura, tendo a soja como o produto agrícola que mais gera receita no Estado. Cultivada em 26 dos 52 municípios e conforme dados da 
CONAB, em 2014/15 foi considerado o estado com maior expansão percentual de área de soja no país.

De acordo com Aragão; Pfeifer; Bomero (2014), partir do século XX, a bovinocultura passa a contribuir social e economicamente para o desenvolvimento regional de Rondônia, já que a criação de gado teve grande contribuição ao fixar inúmeras famílias no campo, ou seja, 26,45\%, da população concentrada na zona rural, conforme dados do último censo.

\begin{abstract}
Nas últimas 5 décadas o número de domicílios rurais em Rondônia cresceu de 10,0 mil para 118,4 mil propriedades, isto representa um crescimento de $1.076,83 \%$, com uma taxa média de ocupação anual de $21,53 \%$. Tendo-se acentuado nas décadas de 1980 e 1990 , com uma ocupação na ordem de $383,52 \%$ e $108,82 \%$, em relação à década anterior, respectivamente. (ARAGÃO; PFEIFER; BOMERO, 2014, p.160)
\end{abstract}

A pecuária tem uma base exportadora de carne bovina, o que contribuiu para a instalação e funcionamento de 25 frigoríficos. O rebanho de Rondônia em 2012 foi o $8^{\circ}$ do país e $2^{\circ}$ da Região Norte, com uma cadeia produtiva de carne de, dois milhões de cabeças de gado abatida. Servindo para o abastecimento de cinco curtumes e 52 salgadeiras de couros bovinos. (ARAGÃO; PFEIFER; BOMERO, 2014).

No período de 2002 a 2010, os valores exportados aumentaram de 73,3 para 426,9 mil dólares, mantendo uma variação média de $28,33 \%$ ao ano, ao mesmo tempo em que a importação cresceu de 88,9 para 235,2, mantendo uma variação de $58,10 \%$ ao ano. Com exceção ao ano de 2002 sempre se exportou mais do que importou, obtendo-se uma diferença em valores exportados de 44,9\% para o ano de 2010. (ARAGÃO; PFEIFER; BOMERO, 2014).

De acordo com dados extraídos da Secretaria de Estado do Planejamento e Coordenação Geral de Rondônia (SEPOG), Rondônia é considerado o maior produtor de leite da Região Norte, participando com 43,2\% no total. Na atividade industrial, a composição é pela indústria extrativa mineral, indústria de transformação, produção e distribuição de eletricidade, gás e água e construção civil (SEPOG, 2012). 
Diante dos dados apresentados, pode-se ter uma visão da localização e do ambiente em que se encontra a Instituição pesquisada e com isso contemplar mesmo que superficialmente a demanda de serviços pelo Estado e oferta de serviços pelo IFRO como contribuição à sustentabilidade.

Sendo assim, cabe apresentar em que contexto o IFRO tem auxiliado para o desenvolvimento de Rondônia com as ações voltadas de preparação e formação da população, principalmente a população considerada produtiva sob o ponto de vista econômico, pois identificando as ações desenvolvidas pelo IFRO em favor da sustentabilidade em todas as suas dimensões, auxiliará na direção para conhecer a cultura organizacional.

A Instituição pertence a uma Rede Federal de Educação Profissional, Científica e Tecnológica quase centenária, que teve sua origem no Decreto n. ${ }^{\circ} 7.566$, de 23 de setembro de 1909, assinado pelo Presidente Nilo Peçanha, através do qual foram criadas 19 Escolas de Aprendizes Artífices. Uma em cada capital federativa, para atender os filhos dos desfavorecidos da fortuna, ou seja, as classes proletárias da época (IFRO, 2014).

O IFRO é uma autarquia federal vinculada ao Ministério da Educação (MEC), criada pela Lei n 11.892 , de 29 de dezembro de 2008, que reorganizou a Rede Federal de Educação Profissional, Científica e Tecnológica, transformando as escolas técnicas, agrotécnicas e centros federais de educação tecnológica (CEFETs), em 38 Institutos Federais de Educação, Ciência e Tecnologia distribuídos em todo o território nacional (BRASIL, 2008).

Em Rondônia, o Instituto surgiu como resultado da integração da Escola Agrotécnica Federal de Colorado do Oeste, com 15 anos de existência, e da Escola Técnica Federal de Rondônia (naquela ocasião em processo de implantação).

Segundo Búrigo e Martins (2015), a expansão da Rede Federal de Educação Profissional e Tecnológica deu um salto em número de unidades de ensino e matrículas, 
passando de 140 unidades em 2002 para 562 em 2014, e as matrículas no período de 2005 a 2014, passaram de próximo de 200.000, para quase um milhão.

A Instituição é detentora de autonomia administrativa, patrimonial, financeira, didático-pedagógica e disciplinar, equiparada às universidades federais. Atua na área de educação básica e superior, em diferentes níveis e modalidade de ensino, assim como em diversos eixos tecnológicos e áreas de conhecimento. (IFRO, 2014).

Segundo o Plano de Desenvolvimento Institucional (PDI), desenvolvem-se programas de pesquisa e extensão voltados para a produção cultural, empreendedorismo, cooperativismo, inovação e transferência de tecnologias com ênfase no desenvolvimento da sociedade regional e na preservação do meio ambiente, transformados em oferta de produtos e serviços. O IFRO possui em seu quadro funcional 864 servidores, sendo 441 docentes e 423 técnicos administrativos. Conforme o Quadro 2 é apresentado a missão, visão e valores da Instituição: Quadro 2 - Identificação da missão, visão e valores do IFRO

\begin{tabular}{|c|l|}
\hline Missão & $\begin{array}{l}\text { O Instituto Federal de Educação, Ciência e Tecnologia de } \\
\text { Rondônia, tem como Missão, promover educação científica } \\
\text { e tecnológica de excelência no Estado de Rondônia voltada } \\
\text { à formação de cidadãos comprometidos com om o } \\
\text { desenvolvimento e a sustentabilidade da sociedade (grifo } \\
\text { nosso) }\end{array}$ \\
\hline Visão & $\begin{array}{l}\text { Tornar-se padrão de excelência no ensino, pesquisa e } \\
\text { extensão na área de Ciência e Tecnologia }\end{array}$ \\
\hline Valores & $\begin{array}{l}\text { Nas suas atividades, o IFRO valorizará o compromisso ético } \\
\text { com responsabilidade social, o respeito à diversidade, à } \\
\text { transparência, a excelência e à determinação em suas ações, } \\
\text { em consonância com os preceitos básicos de cidadania e } \\
\text { humanismo, com liberdade de expressão e atos consonantes } \\
\text { com os preceitos da ética pessoal e profissional, com os } \\
\text { sentimentos de solidariedade, com a cultura da inovação e } \\
\text { com os ideais de sustentabilidade social e ambiental. } \\
\text { (grifo nosso) }\end{array}$ \\
\hline
\end{tabular}

Fonte: (IFRO, 2014)

A Instituição é composta por uma Reitoria com sede na capital do Estado, Porto Velho e por oito campi: Campus Colorado do Oeste, Campus Ji-Paraná, Campus Ariquemes, Campus Porto Velho Calama, Campus Zona Norte, Campus Vilhena, Campus Cacoal e o Campus Guajará-Mirim, iniciando suas atividades em 2016.

Ao todo, o Instituto atende além dos oito municípios mencionados, outros 17 municípios com os polos de Educação a Distância, alcançando, uma dimensão de 25 
municípios, dos 52 contidos no Estado. Os polos de EAD, instalados no interior do estado, ofertam, em parceria com o Instituto Federal do Paraná e o Instituto Federal do Rio Grande do Norte, cerca de 8.100 vagas e estão subordinados à administração do Campus Porto Velho Zona Norte. Já os polos que têm em sua localidade uma sede ficam sob a responsabilidade do respectivo Campus (IFRO, 2014).

A estrutura multicampi possibilita a descentralização e a autonomia para os campi na operacionalização de suas ações. É caracterizada também por uma estrutura organizacional administrativa, didático-pedagógica independente e por orçamentos individualizados para cada campus. No entanto, são amparados por diretrizes institucionais sistêmicas, sendo que cada unidade possui regimento e organização didática próprios, elaborados seguindo as diretrizes institucionais a partir do Estatuto e Regimento Geral emanadas do Colégio de Dirigentes e Conselho Superior (IFRO, 2014).

De acordo com os valores movimentados por ano, tendo como base o exercício financeiro de 2015, o montante é de R \$ R \$ 140 milhões. É possível visualizar o impacto que o IFRO exerce no setor de compras e serviços. Desmembrando esse valor por categoria econômica tem-se a despesa de R\$ 128 milhões de reais com manutenção (custeio), sendo que 84 milhões são destinados ao atendimento da folha de pagamento e 14 milhões para despesas com investimento, dentre obras e materiais permanentes. (SIAFI GERENCIAL, 2016).

O Siafi Gerencial (2016) também permitiu que fossem identificados os maiores valores de custeio no IFRO. Com exceção da folha de pagamento, diárias, passagens e bolsas de estudo diversas, impactam em R \$11,58 milhões com serviços terceirizados, como locação de mão de obra, serviço de limpeza e conservação e serviço de vigilância. O serviço de fornecimento de energia elétrica fica em torno de $\mathrm{R} \$ 2,57$ milhões e serviço de fornecimento de água, tratamento de esgoto e telecomunicações ficam $\mathrm{R} \$ 528$ mil reais. 
Outras grandes despesas com custeio estão os materiais de consumo como: gêneros alimentícios R \$ 1,39 milhões; material de expediente, combustíveis e lubrificantes, alimento para animais, material de processamento de dados, material de acondicionamento e embalagens, material de construção, material elétrico e eletrônico, com aproximadamente R\$ 2,09 milhões. Materiais estes passíveis de inserção de critérios sustentáveis em sua aquisição.

\subsection{População e amostra}

O universo da pesquisa de campo foram os 122 servidores envolvidos nos processos de compras governamentais dos sete campi e da Reitoria do IFRO, com retorno de 85 questionários preenchidos, perfazendo o total de próximo de $70 \%$ da população. Os servidores que não participaram da pesquisa, foi em razão de não estarem presentes durante o período da aplicação dos questionários por motivos de afastamentos como licenças, férias e outras ocorrências funcionais. Não foi pesquisado o campus Guajará-Mirim em razão que sua execução está sendo realizada na Reitoria. A amostra foi do tipo estratificada, pois houve uma seleção prévia entre os setores.

Os respondentes desta pesquisa foram os servidores que desempenham ou que já desempenharam atividades nos setores de Coordenação de Compras e Licitação (CCL); Coordenação de Almoxarifado e Patrimônio (CPALM); Coordenação de Serviços Gerais (CSG); Coordenação de Gestão de Contratos (CGCON) e os servidores da alta gestão, pelas Diretorias Gerais e Diretoria de Planejamento e Administração dos campi, Reitor; PróReitoria de Planejamento e Administração (PROPLAD); Pró-Reitoria de Desenvolvimento Institucional (PRODIN).

Os participantes selecionados foram os servidores que mais se vinculavam com o processo de compras governamentais do IFRO, ao passo que, afirma Creswell (2010), ser uma vantagem a seleção intencional dos participantes para este tipo de coleta de dados. 
Para identificar os participantes, bem como a quantidade de servidores ligados aos setores, foi primeiramente consultado aos Diretores de Planejamento e Administração (DPLAD) a indicação de quais e quantos servidores estavam lotados ou que desempenhavam as atividades inerentes ás compras, para que posteriormente fossem entregues os questionários e apresentados à pesquisa.

Os setores em que os servidores participantes estão lotados desenvolvem atribuições de solicitação de serviços e materiais a serem licitados, elaboração de editais, termos de referência e contratos, executam a licitação, decidem o que serão ou não adquiridos, gerenciam e executam o orçamento, recebem, fiscalizam e atestam os materiais e serviços licitados, enfim, desempenham atividades inerentes às compras governamentais, desde a organização e recepção das solicitações até a fase da aquisição ou contratação.

Como pode ser observado pela descrição das atribuições, geralmente quem exerce as atividades inerentes aos setores objeto desta pesquisa, são os técnicos administrativos, porém como as nomeações para as funções de certas atividades são de competência do dirigente máximo, os servidores docentes também são nomeados para desempenharem tais funções administrativas.

\subsection{Caracterização do instrumento de pesquisa}

$\mathrm{O}$ instrumento de pesquisa utilizado neste estudo referente às dimensões: demográfica e funcional; comportamento dos atores quanto à sustentabilidade ambiental; rotina envolvida no processo de compras e cultura organizacional sobre a sustentabilidade ambiental foi o questionário, elaborado pela própria autora, tendo-se baseado o conteúdo das perguntas com referências em outros estudos, como, Teixeira (2013), Oliveira e Santos (2015), Couto e Coelho (2015), conforme constante no Apêndice B. O questionário incorreu em variáveis 
qualitativas e quantitativas, ordenadas em sua maioria por meio de escala de Likert, a fim de possibilitarem tratamentos estatísticos considerados necessários para a pesquisa.

Para a confecção do questionário quanto às posições das questões, tipo de escala, formatação e modelo de apresentação, foi utilizado (MALHOTRA, 2004). As informações a respeito das variáveis contempladas nas referidas dimensões estão dispostas no Quadro 3.

Quadro 3 - Dimensões abordadas pelo questionário adotado na pesquisa

\begin{tabular}{|c|c|}
\hline Dimensão & Variáveis \\
\hline Demográfica e funcional & $\begin{array}{l}\text { Idade, gênero, grau de instrução, formação, campus que } \\
\text { trabalha, setor de lotação, cargo que ocupa, tempo de serviço } \\
\text { público, experiência em compras públicas em serviço } \\
\text { anterior ao IFRO e a relação do servidor com o trabalho que } \\
\text { desempenha. }\end{array}$ \\
\hline $\begin{array}{l}\text { Comportamento dos atores quanto à sustentabilidade } \\
\text { ambiental }\end{array}$ & $\begin{array}{l}\text { Conhecimento, interesse, aceitação e percepção sobre a } \\
\text { temática da sustentabilidade ambiental e as CPS, legislação } \\
\text { correlata com as compras públicas sustentáveis e a Política } \\
\text { Nacional de Desenvolvimento Sustentável. Percepção das } \\
\text { dificuldades e dos impulsionadores atrelados às CPS. }\end{array}$ \\
\hline Rotina envolvida no processo de compras & $\begin{array}{l}\text { Atual situação frente às compras e contratações de serviços } \\
\text { na Instituição, bem como quais os problemas na execução da } \\
\text { licitação; a caracterização dos fornecedores; critérios } \\
\text { utilizados para a contratação de bens e serviços; como são } \\
\text { descritos os materiais ou serviços pelos demandantes; quais } \\
\text { setores são responsáveis pelo recebimento e organização das } \\
\text { solicitações da demanda de serviços e materiais; o que mais } \\
\text { ocorre nas contratações; quais procedimentos são adotados } \\
\text { pelo setor de compras para adquirir produtos de melhor } \\
\text { qualidade; qual orientação é a mais difundida quanto aos } \\
\text { critérios a serem inseridos nas aquisições; se há uma } \\
\text { integração entre os setores envolvidos nos processos de } \\
\text { aquisições de bens e serviços; quais setores são responsáveis } \\
\text { pelo recebimento de materiais e se há uma fiscalização } \\
\text { efetiva; se há a inclusão de critérios sustentáveis nas } \\
\text { licitações; se são priorizados os fornecedores de pequena e } \\
\text { microempresa nos certames licitatórios, e ainda algumas } \\
\text { variáveis que indicavam se a Instituição está adquirindo e } \\
\text { contratando bens e serviços com critérios sustentáveis, como } \\
\text { menor número de embalagens, uso de refil, reciclados e } \\
\text { recicláveis, alimentos orgânicos; eficiência energética, } \\
\text { menor consumo de água e maior durabilidade. }\end{array}$ \\
\hline Cultura organizacional sobre sustentabilidade ambiental & $\begin{array}{l}\text { O que está sendo praticado pela Instituição ao que tange o } \\
\text { fomento da sustentabilidade; se há na estrutura algum setor } \\
\text { ou servidor responsável pelas questões ambientais; se no } \\
\text { âmbito jurídico há orientação clara e concisa de como deve } \\
\text { ser o cumprimento da legislação sobre as CPS e o grau de } \\
\text { aceitação das CPS sob o ponto de vista pessoal e } \\
\text { organizacional. }\end{array}$ \\
\hline
\end{tabular}


O questionário passou por pré-teste a três servidores, a fim de realizar uma validação dos principais assuntos abordados, principalmente na dimensão sobre a rotina que envolve os processos de compras, culminando em transformações de algumas questões que, até então, estavam dispostas como questões abertas; no entanto foram alteradas para, fechadas. Questões que poderiam ser pesquisadas por outra fonte de evidência foram retiradas do questionário para não cansar o respondente e com isso obter uma melhor fidedignidade com as respostas.

\subsubsection{Avaliação do Instrumento de Pesquisa}

Para a verificação quanto à confiabilidade das escalas das variáveis do questionário, foi utilizado o alpha de Cronbach. Segundo HAIR et al. (2005); PESTANA e GAGEIRO (2005) e utilizado por Almeida (2010), o alpha de Cronbach é uma das medidas mais usadas para verificação da consistência interna de um grupo de variáveis. A aplicação desta medida serviu para avaliar se as variáveis consideradas na escala são altamente intercorrelacionadas.

A confiabilidade avaliada pelo alpha de Cronbach varia de 0 a 1 que, quanto mais próximo de 1, maior a indicação da confiabilidade. Segundo Hair et al. (2005) os valores de 0,60 a 0,70 são considerados o limite inferior de aceitabilidade.

Os resultados obtidos pelas variáveis em escala ordinal nas dimensões referentes ao comportamento dos atores quanto à sustentabilidade ambiental e a rotina envolvida no processo de compras foram 0,640 e 0,716 , respectivamente, considerados adequados.

\subsection{Procedimentos de coleta e de análise de dados}

Anterior à coleta dos dados pelos questionários, houve acompanhamento durante 15 dias aos setores de Compras e Licitação e de Planejamento e Administração, em um dos campi agrícola, a fim de conhecer a rotina que envolve as compras na Instituição. Para este acompanhamento foi utilizado o método da observação participante, proposto por Vergara 
(2013), cujos dados registrados foram: o que se contrata, como ocorre a tramitação dos processos licitatórios; como é feita a cotação prévia de preços obrigatória no Termo de Referência (documento contemplado no edital de licitação); o que consta no parecer da Procuradoria Jurídica e os próprios editais de licitação com os respectivos anexos. A fim de entender como é constituído o processo licitatório e o comportamento do servidor frente às práticas adotadas pela Instituição.

Os questionários foram aplicados pela própria autora da pesquisa em todos os campi $\mathrm{e}$ na Reitoria no mês de outubro de 2015. Na aplicação, houve a oportunidade de apresentar o objetivo da pesquisa aos servidores e entregar aos Diretores-Gerais e aos Diretores de Planejamento e Administração de cada Campus e da Reitoria, uma carta de apresentação baseada em Yin (2010) para formalizar a pesquisa que estava ocorrendo na Instituição, principalmente por se tratar de um estudo de caso.

Esta carta contemplou informações como a identificação da pesquisadora, a Instituição que está vinculada ao programa da pós-graduação, o objetivo, o tipo e o universo da pesquisa, bem como ainda solicitou colaboração para o seu desenvolvimento.

A aplicação presencial do questionário proporcionou uma interação com os respondentes gerando um feedback mais rápido devido ao interesse demonstrado pelos mesmos. Nesta ocasião, foi percebida uma preocupação entre alguns respondentes sobre a atual execução das compras públicas sustentáveis dentro da Instituição, principalmente dos servidores ocupantes de cargos da alta gestão, como Diretores e Coordenadores.

Concomitante à coleta dos dados pelos questionários, também foram efetuadas pesquisas documentais, telematizadas e bibliográficas, a fim de obter informações como: número de licitações sustentáveis praticadas no período de 2010 a 2015; valores das respectivas compras; natureza dos materiais e serviços contratados; valores dos orçamentos anuais aprovados para a Instituição; documentos de Registro da Instituição. 
As pesquisas documentais e a observação participante nos setores visitados foram necessárias para a obtenção dos dados relacionados ao conteúdo dos editais de licitação, verificados na ocasião por alguns processos licitatórios, na modalidade pregão eletrônico no, sistema de registro de preços (SRP); pareceres da procuradoria jurídica; normativas; portarias e outros documentos correlatos que dispõem de informações relacionadas às práticas de licitações.

$\mathrm{Na}$ pesquisa telematizada, pelo portal de compras do governo administrado pelo MPOG, foram coletados os dados referentes aos valores das licitações tradicionais e sustentáveis. No site da Instituição foram vistos, além dos documentos inerentes ao registro da Instituição, como histórico, Plano de Desenvolvimento da Instituição (PDI); Regimentos; Organogramas; Resoluções e outros referentes à constituição do IFRO, também editais de licitação publicados.

No google acadêmico, por meio de um cadastro prévio, eram recebidos semanalmente materiais bibliográficos publicados nos periódicos e demais meios de divulgação, a partir de alertas desse recurso tecnológico.

Como o foco deste estudo foi área de Gestão Pública e Sustentabilidade, a atenção especial foi para os materiais constantes nos periódicos: Revista de Administração Pública (RAP); Revista do Serviço Público (RSP); Revista Gestão, Inovação e Negócios; Revista de Administração de Empresas (RAE); Revista Gestão Universitária na América Latina GUAL, além dos Anais da ANPAD e dissertações e teses.

Também para compor o referencial teórico foram utilizados materiais bibliográficos apresentado pelos professores durante o curso de mestrado profissional em Gestão Pública, pela UnB, como artigos, livros, manuais e coletâneas, indicados pelos professores das disciplinas correlatas. Outro instrumento de grande utilidade foi um artigo com a bibliometria sobre o tema, o qual continha um mapeamento da produção científica. 
Para informações complementares, foi utilizado um cadastro junto ao Instituto de Logística Pública que, por meio de boletins de notícias, os assuntos relacionados ao tema sustentabilidade, como por exemplo, benefícios à micro e empresa de pequeno porte em licitações, agricultura familiar, alterações em normas de licitação e outros assuntos referentes às compras públicas puderam ser verificados e atualizados.

Para consecução dos objetivos propostos, os dados coletados pelas questões fechadas foram aplicados técnicas de estatísticas descritivas e inferenciais, contando com análises multivariadas para explicar os aspectos analíticos da pesquisa, bem como quantificar os resultados das análises obtidas. O instrumento utilizado para a aplicação e inserção dos dados foi o pacote estatístico SPSS.

A estatística descritiva foi utilizada para demonstração da análise exploratória, pois tem como principal objetivo a apresentação dos dados obtidos serem avaliados e consistem na coleta, análise e interpretação. Os resultados dessa análise foram apresentados na forma de tabelas, quadros, figuras ou gráficos.

$\mathrm{Na}$ estatística inferencial usou-se a ferramenta para testes não paramétricos, como o Teste $U$ de Mann-Whitney, principalmente por apresentarem dados em escala ordinais e pelo teste não exigir normalidade entre as variáveis submetidas. Foi utilizada também a análise de correlação e análise fatorial por serem ferramentas muito úteis na aplicação de pesquisas com dados exploratórios.

O teste $U$ de Mann-Whitney faz parte dos testes não paramétricos para utilização em amostras independentes. Conforme prevê Pestana e Gageiro (2005), sua aplicação é uma alternativa ao teste $t$, pois enquanto o teste paramétrico $t$ compara as médias de duas amostras independentes, o teste $U$ de Mann-Whitney compara a tendência central de duas amostras, como forma de detectar diferenças estatísticas entre as duas populações. 
O teste $U$ de Mann-Whitney foi aplicado para avaliar se há diferenças estatísticas entre a percepção dos servidores lotados nos campi e na Reitoria a respeito das variáveis que representaram a rotina envolvida no processo de compras do IFRO.

As hipóteses analisadas pelo teste $\mathrm{U}$ foram as seguintes:

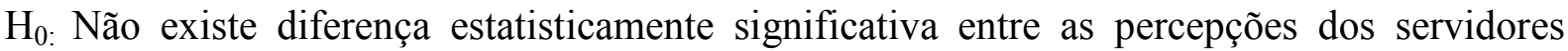
lotados na Reitoria e nos Campi do IFRO quanto à rotina que envolve os processos de compras;

H1: Existe diferença estatisticamente significativa entre as percepções dos servidores lotados na Reitoria e nos Campi do IFRO quanto à rotina que envolve os processos de compras.

Outra análise utilizada foi a de Correlação, pois é a ferramenta estatística que demonstra a existência de associação entre duas variáveis, estudando o grau de relacionamento entre elas. Esse método mede a intensidade e a direção da relação entre as variáveis. A intensidade de associação existente é representada pelo coeficiente de correlação produto-momento (r), como sua fórmula de cálculo foi proposta por Karl Pearson em 1896, ficou conhecido também como coeficiente de correlação de Pearson. Esse coeficiente varia de $-1 \mathrm{a}+1$. Quanto à direção da relação, diz-se que possui correlação direta e inversa, sendo representada por valores positivos e negativos, respectivamente.

A análise de correlação foi utilizada, neste estudo, com a finalidade de identificar a relação entre as variáveis que representou a frequência de solicitação de material ou serviço com inclusão de critérios sustentáveis e o apoio da gestão voltada à CPS e aceitação das CPS pela organização.

A análise fatorial é uma técnica exploratória que examina as relações em um grande número de variáveis com o objetivo de reduzi-las mantendo o maior poder de explicação pelas variáveis representativas. De acordo com HAIR et al. $(2005$, p.91) “o novo conjunto de dados criado pela análise é definido como um conjunto de dimensões latentes comuns, 
chamadas de fatores". Tem substancial importância para outras técnicas multivariadas por disponibilizar resumo e redução de dados. Esse resumo de dados faz da identificação das dimensões um fim em si própria, a análise requer apenas as estimativas dos fatores e a identificação das cargas fatoriais que são as contribuições de cada variável aos fatores.

A análise fatorial foi utilizada para agrupar as variáveis relacionadas ao conhecimento do tema sustentabilidade com o conhecimento das compras sustentáveis, bem como com a participação em eventos. Serviu também para agrupar as variáveis relacionadas ao interesse pelo tema em questão e a predisposição favorável às práticas que contribuem para diminuir impactos negativos ao meio ambiente, mesmo quando consideradas mais dispendiosas.

Para entender como foi utilizada cada ferramenta para o atendimento dos objetivos, segue a apresentação no Quadro 4.

Quadro 4 Ferramentas utilizadas para os objetivos da pesquisa

\begin{tabular}{|ll|l|}
\hline \multicolumn{1}{|c|}{ OBJETIVOS: } & \multicolumn{1}{|c|}{ FERRAMENTAS UTILIZADAS } \\
\hline a) & $\begin{array}{l}\text { Analisar a evolução das compras públicas } \\
\text { sustentáveis em comparação com a taxa de } \\
\text { crescimento }\end{array}$ & Estatísticas descritivas. \\
\hline b) & $\begin{array}{l}\text { Descrever o perfil dos servidores que estão } \\
\text { envolvidos aos processos de compras } \\
\text { governamentais no IFRO }\end{array}$ & Estatística descritiva; \\
\hline c) & $\begin{array}{l}\text { Avaliar a percepção dos servidores do IFRO } \\
\text { que estão envolvidos no processo de } \\
\text { compras, em relação às compras públicas } \\
\text { sustentáveis e identificar as principais } \\
\text { dificuldades na implementação }\end{array}$ & Estatística descritiva; análise fatorial, análise de \\
d) & $\begin{array}{l}\text { Analisar as ações relacionadas ás compras análise de conteúdo. } \\
\text { governamentais efetuadas pelo IFRO }\end{array}$ & Estatística descritiva; análise de conteúdo; teste $U$ de \\
& $\begin{array}{l}\text { Mann Whitney } \\
\text { cultura da sustentabilidade no IFRO }\end{array}$ & Estatística descritiva; análise de conteúdo e análise de \\
&
\end{tabular}
Fonte: Elaboração da autora

Os dados das questões abertas foram lançados em planilha do Excel, a fim de serem analisadas com a ferramenta de filtro das respostas e análise de conteúdo. Para a avaliação das respostas com perguntas abertas empregou-se a análise de conteúdo proposta por Bardin (2011), pois define o conjunto de técnicas de análise das comunicações visando obter, por procedimentos sistemáticos e objetivos, a descrição de conteúdo das mensagens, com 
indicadores (quantitativos ou não) e ainda permitem a inferência de conhecimentos relativos às condições de produção/recepção. 


\section{RESULTADOS E DISCUSSÕES}

O capítulo sobre os resultados e a discussão optou-se pela apresentação conjunta por se tratar de pesquisa com abordagem mista conforme sugestão proposta por Creswell (2010). Os resultados dos dados documentais e telematizados estão diluídos e discutidos entre os resultados dos dados primários nas discussões.

\subsection{Evolução das CPS - Panorama das CPS na União e no IFRO}

Desde a promulgação da Instrução Normativa $n^{\circ}$ 01/2010, mesmo que timidamente, vem se introduzindo na rotina dos gestores públicos brasileiros as contratações públicas sustentáveis. O desdobramento da política de sustentabilidade nas compras públicas pode ser acompanhado no portal de compras do governo, alimentado pelo MPOG, em link específico sobre compras sustentáveis.

Os dados apresentados na Tabela 2 evidenciaram que, mesmo havendo uma crescente participação das CPS em relação às compras convencionais, ainda é muito inexpressiva, pois desde a sua inclusão não chegou ao patamar de 0,1 por cento no período de 2010 até 2014.

Tabela 2 - Participação das CPS no total das compras governamentais e evolução

\begin{tabular}{r|r|r|r|r}
\multicolumn{1}{c|}{ Ano } & \multicolumn{1}{c}{$\begin{array}{c}\text { CPS R\$ em } \\
\text { milhões }\end{array}$} & $\begin{array}{l}\text { Evolução das CPS } \\
\text { em relação ao ano } \\
\text { anterior em \% }\end{array}$ & $\begin{array}{l}\text { Compras Públicas } \\
\text { R\$ em bilhões }\end{array}$ & $\begin{array}{l}\text { Percentual das CPS sobre } \\
\text { as Compras Públicas }\end{array}$ \\
\hline $2010^{1}$ & $14.297 .565,89$ & $\ldots$ & $84.103 .328 .764,71$ & 0,017 \\
\hline 2011 & $8.437 .929,57$ & $-40,98$ & $39.364 .512 .983,60$ & 0,021 \\
\hline 2012 & $23.028 .084,06$ & 172,91 & $68.877 .160 .212,04$ & 0,033 \\
\hline 2013 & $28.977 .858,44$ & 25,84 & $52.793 .483 .389,66$ & 0,055 \\
\hline 2014 & $33.410 .626,08$ & 15,30 & $76.555 .088 .624,13$ & 0,044 \\
\hline 2015 & $130.788 .407,16$ & 291,46 & $45.125 .100 .744,37$ & 0,290 \\
\hline TOTAL & $\mathbf{2 3 8 . 9 4 0 . 4 7 1 , 2 0}$ & & $\mathbf{3 6 6 . 8 1 8 . 6 7 4 . 7 1 8 , 5 1}$ & \\
\hline${ }^{1}$ MPOG (2014). \\
Fonte: MPOG (2016)
\end{tabular}

Quanto às participações dos órgãos com maiores valores despendidos nas CPS relativo ao exercício financeiro de 2015, para fins de comparação com o exercício anterior, observa-se que os que se destacaram foram: Ministério da Educação; Ministério da Saúde e Previdência Social, conforme demonstrados na Tabela 3. 
Tabela 3 - Órgãos com valor acima de R\$ 1 milhão nas CPS no período de 2014 a 2015

\begin{tabular}{lrr}
\hline \multicolumn{1}{c}{ Órgão Superior } & \multicolumn{1}{c}{$2014(\mathrm{R} \$)$} & \multicolumn{1}{c}{$2015(\mathrm{R} \$)$} \\
MINISTÉRIO DA EDUCAÇÃO & $13.700 .717,08$ & $106.034 .517,16$ \\
MINISTÉRIO DA SAÚDE & $990.570,32$ & $9.892 .584,76$ \\
MINISTÉRIO DA PREVIDÊNCIA SOCIAL & $6.966 .201,11$ & $3.622 .017,82$ \\
MINISTÉRIO DA DEFESA & $222.962,94$ & $2.689 .266,98$ \\
PRESIDÊNCIA DA REPÚBLICA & $5.502 .912,94$ & $2.638 .901,98$ \\
MINISTÉRIO DA FAZENDA & $1.722 .620,36$ & $1.994 .310,43$ \\
MINISTÉRIO DA JUSTIÇA & $1.216 .451,14$ & $1.260 .859,06$ \\
OUTROS & $3.088 .190,19$ & $2.655 .948,98$ \\
TOTAL & $\mathbf{3 3 . 4 1 0 . 6 2 6 , 0 8}$ & $\mathbf{1 3 0 . 7 8 8 . 4 0 7 , 1 7}$ \\
\hline
\end{tabular}

Fonte: MPOG (2016)

Valores destacados houve diminuição em 2015.

Com exceção do Ministério da Previdência Social e da Presidência da República que tiveram reduções próximas de 52\% e 48\% respectivamente, todos os órgãos presentes na Tabela em 2014 tiveram aumentos que, somados ultrapassaram a média dos R \$ 28,5 milhões relativos aos anos anteriores (2011 a 2014), para aproximadamente 131 milhões em 2015, culminando com isso em fato inédito em atingir 0,290 por cento das compras tradicionais que, desde 2010, o maior limite alcançado foi de 0,063 .

O MEC teve a principal contribuição para esse crescimento, pois a diferença em relação a 2014 foi de R $\$ 92,33$ milhões, respondendo por 81\% de todas as CPS no exercício financeiro de 2015, seguido do Ministério da Saúde e Ministério da Defesa.

\section{Dados do IFRO}

Antes de apresentar as informações telematizadas, cabe primeiramente apresentar a demanda de materiais e serviços do IFRO a fim de conhecer as naturezas das despesas utilizadas. Com o conhecimento dos materiais e serviços necessários na manutenção da Instituição, é possível fazer associação com as informações prestadas pelos servidores por meio dos questionários, inclusive quanto à indicação dos bens que porventura possam sofrer inserção de critérios sustentáveis.

A demanda de materiais e serviços do IFRO foi disponibilizada pelos Diretores de Planejamento e Administração quando da aplicação dos questionários e durante o período da observação participante no Campus Colorado do Oeste. Nesse período foi autorizada consulta 
à planilha em que são controladas as licitações por unidade gestora (UG), conforme dados demonstrados no Quadro 5.

A referida planilha é compartilhada entre os servidores envolvidos no processo de compras, no google docs. Os diretores também informaram que a maioria das licitações realizadas na Instituição é na modalidade de pregão eletrônico, no sistema de registro de preços (SRP). Com exceção das obras que, até meados de 2014, eram licitadas geralmente nas modalidades de Concorrência, antes de adotarem o Regime Diferenciado de Contratação (RDC).

Quadro 5 - Materiais e Serviços Demandados e Licitados pela Instituição

\begin{tabular}{|c|c|}
\hline Materiais de Consumo: & $\begin{array}{l}\text { Gêneros alimentícios; alimentação para animais; materiais de } \\
\text { construção, como hidráulico, elétrico e demais materiais para } \\
\text { manutenção de bens imóveis; material de limpeza; copa e } \\
\text { cozinha; proteção e segurança; insumos para produção } \\
\text { agrícola, como fertilizantes, venenos, herbicidas, fungicidas, } \\
\text { inseticidas e outros; sementes; ferramentas; combustíveis e } \\
\text { lubrificantes; peças para veículos; produtos e medicamentos } \\
\text { veterinários; gás engarrafado, como GLP, nitrogênio; } \\
\text { reagentes; material químico; material para laboratório; } \\
\text { aquisição de sêmen bovino; animais para pesquisa e abate; } \\
\text { material de expediente; embalagens; medicamentos; material } \\
\text { hospitalar; Processamento de Dados; material bibliográfico; } \\
\text { uniformes; material esportivo; pneus; }\end{array}$ \\
\hline Materiais Permanentes & $\begin{array}{l}\text { Veículos; equipamentos de processamento de dados; } \\
\text { refrigeração; equipamentos industriais; equipamento de } \\
\text { áudio, vídeo e foto; mobiliários; implementos agrícolas; } \\
\text { instrumentos musicais; material bibliográfico; equipamento } \\
\text { esportivo }\end{array}$ \\
\hline Serviços Comuns & $\begin{array}{l}\text { Serviços gráficos; limpeza e conservação; vigilância; } \\
\text { realização de eventos, como hospedagem e alimentação; } \\
\text { locação de mão-de-obra; manutenção e conservação de bens } \\
\text { móveis e imóveis; energia elétrica; serviço de } \\
\text { telecomunicações, fixa, móvel e internet; correspondências e } \\
\text { malotes; seguro para alunos; elaboração de projetos de } \\
\text { engenharia; reprografia; recarga de extintores; fretamento; } \\
\text { dedetização; manutenção de veículos; publicações em jornais } \\
\text { de grande circulação; serviço de treinamento e seleção; } \\
\text { serviço de publicação legal; }\end{array}$ \\
\hline
\end{tabular}

Segundo dados do portal de compras do governo federal, a despesa do IFRO no período de 2011 a 2015, foi de R\$271,56 milhões e, sobre esse montante, as compras sustentáveis corresponderam a R $\$ 199.981,94$, (cento e noventa e nove mil, novecentos e oitenta e um reais e cinquenta e seis centavos), ou seja, um percentual de 0,073 , incluído o valor de R\$ 2.381,70, referente ao exercício de 2010 (MPOG, 2016). 
$\mathrm{Na}$ Tabela 4, estão apresentados os valores das compras do IFRO com o respectivo percentual aplicado nas compras sustentáveis no período de 2010 a 2015. Fazendo um paralelo entre o exercício de 2015, em que houve crescimento considerável das CPS pela União em relação aos exercícios anteriores, principalmente o MEC; no IFRO não ocorreu o mesmo, inclusive houve redução do valor aplicado em relação ao exercício de 2014, tanto na CPS, como nas tradicionais.

Tabela 4 - Participação das CPS no total das compras governamentais do IFRO no período de 2010 a 2015

\begin{tabular}{l|r|c|c}
\hline \multicolumn{1}{|c|}{ Ano } & CPS (R\$) & Compras Públicas (R\$) & $\begin{array}{c}\text { Percentual das CPS } \\
\text { sobre as Compras Públicas }\end{array}$ \\
\hline $2010 *$ & $2.381,70$ & $\ldots$ & $\ldots$ \\
\hline 2011 & $38.627,38$ & $44.298 .856,49$ & $0,087 \%$ \\
\hline 2012 & $56.770,66$ & $50.657 .146,42$ & $0,112 \%$ \\
\hline 2013 & $10.645,60$ & $64.427 .815,22$ & $0,017 \%$ \\
\hline 2014 & $46.819,60$ & $58.079 .024,10$ & $0,081 \%$ \\
\hline 2015 & $44.737,00$ & $54.104 .816,14$ & $0,083 \%$ \\
Total & $\mathbf{1 9 9 . 9 8 1 , 9 4}$ & $\mathbf{2 7 1 . 5 6 7 . 6 5 8 , 3 8}$ & $\mathbf{0 , 0 7 4 \%}$ \\
\hline \multicolumn{2}{l}{ Fonte: * MPOG (2014); MPOG (2016) }
\end{tabular}

No portal de compras do governo federal, também foi efetuada a busca por inserção de contratos firmados pela Instituição com itens sustentáveis, porém não houve incidência registrada. Vale esclarecer que, com a adoção do sistema de registro de preços, geralmente são atribuídas aos contratos, somente as obrigações inerentes a serviços.

\subsection{Dados do Questionário}

A opção pela aplicação presencial dos questionários ao invés do eletrônico foi em razão inclusive de poder perceber a reação dos respondentes e conhecer o ambiente em que são desenvolvidas as compras. Uma frase constantemente mencionada foi: “Olha, nós não estamos fazendo o correto!”. Já para a alta gestão, a preocupação era o “preencher corretamente", inclusive pedindo auxílio aos DPLADs, que, contudo, orientaram para o preenchimento individual, pois o objetivo era justamente a percepção individual de cada servidor. 


\subsubsection{Dimensão Demográfica e Funcional - Perfil dos Respondentes}

Segundo Pfeffer, (1982, p.277 apud EGEBERB, 2010, p.150), a demografia organizacional "refere-se à composição em termos de atributos básicos como idade, sexo, etnia, escolaridade e tempo de serviço da entidade social estudada", e tais fatores devem influenciar o comportamento na tomada de decisão". No Quadro 6 é possível observar os dados demográficos e funcionais desta pesquisa.

De acordo com os dados apurados e demonstrados no Quadro 6, a composição etária dos respondentes apresentou uma média de 34,64 anos e teve maior percentual na faixa entre 31 a 40 anos. Vale dizer que para esta composição da média houve cinco idades que ficaram abaixo de 23 anos e, cinco idades acima de 50 anos, com desvio-padrão de 8,215.

Quadro 6 - Perfil demográfico e funcional dos respondentes

\begin{tabular}{|c|c|c|c|}
\hline \multicolumn{2}{|c|}{ Variáveis Demográficas } & \multicolumn{2}{|c|}{ Variáveis Funcionais } \\
\hline Variável & Percentual & Variável & Percentual \\
\hline Faixa etária: & & Lotação dos Respondentes: & \\
\hline $20-30$ & $35,70 \%$ & Reitoria & $19,77 \%$ \\
\hline $31-40$ & $46,40 \%$ & Campus Calama & $12,79 \%$ \\
\hline $41-50$ & $14,30 \%$ & Campus Zona Norte & $4,65 \%$ \\
\hline $51-60$ & $2,40 \%$ & Campus Ariquemes & $9,30 \%$ \\
\hline \multirow[t]{4}{*}{ acima de 60} & $1,20 \%$ & Campus Ji-Paraná & $10,47 \%$ \\
\hline & & Campus Cacoal & $8,14 \%$ \\
\hline & & Campus Vilhena & $11,63 \%$ \\
\hline & & Campus Colorado do Oeste & $23,26 \%$ \\
\hline Sexo: & & Cargo: & \\
\hline Masculino & $66,28 \%$ & TAE & $88,37 \%$ \\
\hline Feminino & $33,72 \%$ & Docentes & $11,63 \%$ \\
\hline Grau de Instrução: & & Tempo de serviço: & \\
\hline Ensino Médio & $8,14 \%$ & Até 36 meses & $30,95 \%$ \\
\hline Superior Incompleto & $15,12 \%$ & 37-84 meses & $38,10 \%$ \\
\hline Superior Completo & $25,58 \%$ & acima de 85 meses & $30,95 \%$ \\
\hline Especialização & $38,37 \%$ & & \\
\hline Mestrado ou Doutorado & $12,79 \%$ & & \\
\hline
\end{tabular}

Em relação à idade, é pertinente lembrar que para ingresso no serviço público brasileiro, a idade mínima é de 18 anos e geralmente a aposentadoria ocorre entre uma faixa etária de 55 a 65, dependendo do cargo que o servidor ocupa, implicando que, a maioria dos 
servidores respondentes está em idade produtiva sob o ponto de vista de ingresso e egresso das atividades laborais. Quanto ao sexo dos respondentes, 66,28\% dos servidores são do sexo masculino.

Quanto ao grau de instrução, foi salientada a elevada titulação dos servidores, mesmo não sendo exigência para o ingresso, $51 \%$ são pós-graduados em lato e stricto sensu e que apenas sete servidores possui apenas o nível médio, perfazendo um percentual de $8,14 \%$ dos respondentes.

Segundo Castro et al. (2015), as pessoas com nível superior e, consequentemente acima, possivelmente já tiveram informações a respeito de temáticas relativas à sustentabilidade e práticas sustentáveis no meio acadêmico. Considerando que as universidades, em sua grande maioria, estão preocupadas em formar cidadãos com essa visão.

Sustentando a observação de Castro et al. (2015) quanto à preparação dos cidadãos pelas universidades, um compromisso firmado pelo Brasil e devidamente formalizado por meio da Resolução CNE/CP n 02/2012, publicada em 18 de junho de 2012, foi de incluir a sustentabilidade no currículo acadêmico de todas as instituições de ensino superior (VIEGAS; CABRAL, 2015).

Outro instrumento que também coaduna com a informação, em inserir a educação ambiental como tema transversal em todas as grades e cursos foi, a Resolução $n^{0} 254$ da UNESCO, elaborada na Assembleia das Nações Unidas que instituiu, em janeiro de 2005, a Década da Educação para o Desenvolvimento Sustentável (2005-2014), chamando as Instituições de Ensino a cumprirem o seu papel no processo, como responsáveis pela formação de novas ideias (VIEGAS; CABRAL, 2015).

Couto e Coelho (2015) já constataram, em estudos anteriores, a evidência da realidade que os quadros de servidores que ingressaram no serviço público, naquele caso, o Instituto de 
Geografia e Estatística (IBGE), por concurso, 67\% são compostos por servidores especializados, e que há indícios de que a qualificação tem sido estimulada inclusive pelo plano de cargos e carreiras, já que, todavia, são melhores gratificados os servidores com maior titulação.

Assim como o IBGE, que "vem destinando seus servidores mais capacitados (em tese) para atuar nas compras governamentais, possivelmente em virtude da natureza complexa da atividade" (COUTO e COELHO, 2015, p.528), os dados coletados no IFRO confirmaram essa prática.

O Apêndice B apresentou informações quanto à formação, cargo e função dos servidores e, ainda a incidência de titulação superior ao cargo de nível médio, quando aplicado. Dos 86 questionários retornados, 73 responderam a questão referente à formação e 60 quanto ao cargo, já os que responderam a ambas, foram 52 casos.

Contudo, pôde-se verificar que, das 73 respostas quanto à formação, 22 são da área de administração e gestão pública, incluídas tecnologia em gestão pública; 17 são das ciências contábeis; 09 de licenciaturas e 25 distribuídas entre cursos de nível médio; cursos nas áreas de processamento de dados e tecnologia da informação; direito; engenharia agronômica; engenharia civil e arquitetura.

Foi identificado que mais de 30\% tem formação nas áreas de administração e gestão, o que implica em possível contribuição para o desempenho das atividades ligadas ao planejamento e administração.

Outra característica observada no mesmo Apêndice é referente ao cargo dos servidores ligados à área administrativa que desempenham alguma função relacionada às compras, seja na solicitação dos bens e serviços, na licitação e nas compras, na fiscalização e outras. Das 60 respostas que identificaram os cargos, 37 são de nível intermediário ou nível médio e, 23 de nível superior. Desses 37 de nível intermediário, 81\% são de assistente em administração e, 
que dos servidores de nível intermediário que preencheram também o quesito titulação, um grupo de 30 casos, observou-se que $81 \%$ têm titulação acima da exigida para o cargo.

Dos 23 de nível superior, nove são professores; sete são administradores, quatro são contadores e três são de cargos distintos, sendo um tecnólogo em Gestão Pública, um técnico em assuntos educacionais uma nutricionista. Após as análises verificou-se que os servidores responsáveis pelas atividades, objeto desta pesquisa, pertencem em sua maioria aos cargos de assistente em administração, com titulação superior à exigida, formação na área de gestão e administração. Portanto incorrendo numa mão de obra qualificada, se considerado o aspecto da titulação e formação em relação ao cargo.

$\mathrm{Na}$ dimensão funcional foi verificado que a distribuição dos respondentes por unidade de lotação, a Reitoria e o Campus Colorado do Oeste tiveram maior número de participantes na pesquisa. Porém os demais campi apresentaram proximidades quanto ao número de servidores, exceto o Campus Zona Norte, que apenas representou 4,6\% dos respondentes. Esta observação implica que, possivelmente em todos os campi o número de servidores que desempenham atribuições inerentes às compras, é semelhante, variando de 08 a 12 servidores.

Quanto à representação dos cargos, a proporção referente ao cargo de técnico administrativo em educação (TAE) e docente que estão ligados às áreas envolvidas com as compras, conforme os resultados obtidos das 86 respostas, $88 \%$ dos respondentes são TAEs, enquanto que somente $11,63 \%$, são da categoria de docentes, evidenciando a grande participação dos TAEs nas funções relacionadas às compras governamentais na Instituição pesquisada, conforme demonstrado no Quadro 6.

Todavia, a nomeação de funções ou cargos de direção no IFRO, com as equivalentes gratificações, fica a critério do dirigente máximo da Instituição, no caso de campus, o DiretorGeral, no caso da Reitoria, o próprio Reitor. 
Em relação ao tempo de serviço, a média dos servidores respondentes, foi de 81,10 meses, o equivalente há quase sete anos. Esta variável foi categorizada em três faixas: até 36 meses; 37 a 84 e acima de 85 meses. Distinguindo uma categoria da outra, tem-se que na primeira categoria foi considerado o fator estabilidade, todavia que até 36 meses os servidores ainda não adquiriram a estabilidade. Na próxima faixa foram enquadrados os servidores que ingressaram no IFRO a partir da sua criação, 2008, perfazendo um total de sete anos até 2015 e, a última categoria, os servidores que já estavam na Instituição ou no serviço público anterior a criação do IFRO, ou seja, há mais de oito anos.

A maior concentração dentre as faixas do tempo de serviço foram os servidores que se enquadraram na faixa entre 37 a 84 meses, já na condição de estáveis. Se ainda acrescentar a este total, os servidores que já se encontravam na Instituição anterior a 2008, esse percentual sobe para próximo de $70 \%$, evidenciando que a grande maioria dos servidores já está engajada na Instituição.

Ao aspecto condicionado à estabilidade, há que se refletir sobre os servidores que passaram pelo crivo da avaliação de desempenho referente ao estágio probatório e foram aprovados. Subentendendo que estão em consonância e familiarizados com a cultura organizacional da Instituição, ou seja, socializados. Sobre socialização segundo (Egeberg, 2010, p.151), “significa, em geral, que valores, normas e expectativas quanto ao papel a ser desempenhado foram internalizados pelos indivíduos", relembrando o que foi mencionado por. Bilhim (2013) na seção sobre a Cultura Organizacional: quando ocorre essa internalização é justamente quando os novos servidores são devidamente aceitos como membros da organização.

Egeberg (2010) também deixa claro que membros socializados em termos organizacionais demonstram maior identidade com a organização e com isso se espera que defendam seus interesses com maior afinco e de modo automático, sem depender de 
mecanismos como incentivos ou sanções, considerados controle externo. Com essa explanação e considerando a variável relacionada ao tempo de serviço, ficou evidenciado que os servidores do IFRO estão socializados com a cultura da organização.

Duas outras variáveis sobre o perfil dos servidores referem-se, à experiência em processo de compras públicas em serviço anterior ao IFRO e, à afinidade com o serviço que desempenha no setor em que está lotado. As variáveis foram apresentadas na Figura 3 por meio dos gráficos Box Plot, identificando os valores mais distantes da mediana para cada variável.

Figura 3 - Demonstração da experiência em compras públicas anterior ao IFRO e afinidade com o setor em que está lotado

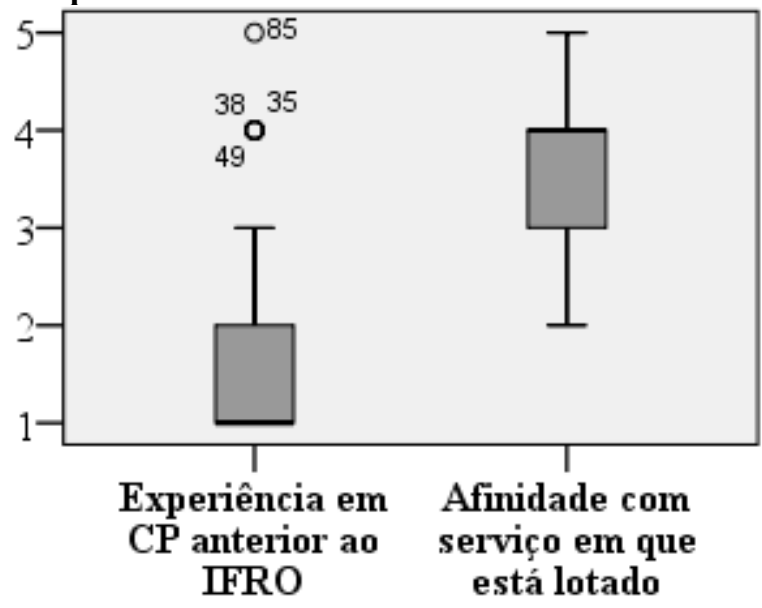

Fonte: Elaboração da autora

A medida de tendência central para a experiência em compras públicas $(\mathrm{CP})$ anterior ao IFRO teve a menor mediana, correspondendo à opção1, (nenhuma experiência), porém com incidência de um caso na opção 5 (muito elevada), apontado pelo respondente de número 85; e três casos apontados para a opção 4, (elevada), por três respondentes com seus respectivos números de identificação.

No entanto, mesmo com a maioria dos servidores apresentando nenhuma experiência relacionada às compras públicas anterior ao IFRO, a variável que demonstrou a afinidade com o serviço em que está lotado, apresentou mediana das respostas na opção (elevada), no 
segundo gráfico da Figura 3. Indicando, uma possível satisfação no quesito afinidade no serviço que desempenha.

Sobre estas variáveis Búrigo e Martins (2015), em estudo que relacionou a gestão de compras com a expansão da rede federal de educação profissional e tecnológica, constataram que com a expansão da Rede, muitos servidores ingressaram no serviço público e foram lotados em setores que desempenham atribuições relacionadas às compras públicas. Contudo, sem experiência e com uma carga e responsabilidade expressiva, pois essas atividades são classificadas como complexas e técnica.

O IFRO, assim como outros Institutos, principalmente os servidores lotados na Reitoria, acarretam mais uma atribuição, a de servir como suporte aos servidores lotados nos campi. Como foi apresentado, de um modo geral nem os servidores lotados na Reitoria vieram com bagagens traduzidas em experiências aos processos de compras, o que culmina em carência de mão de obra experiente e sobrecarga de serviços.

No caso do IFRO, por mais que não disponha de servidores que já tiveram contato com os processos de compras, a situação ainda pode ser considerada favorável, já que a maioria demonstrou que há afinidade com os serviços atribuídos ao setor de lotação. Necessitando, no entanto, se levado em conta a experiência; de preparação, treinamento e adequação para o desempenho das compras.

A vertente de treinamento e preparação das atividades ligadas às compras públicas remete também ao problema desta pesquisa, pois mesmo havendo um fator que contribui, como a afinidade com o setor de lotação, há também um entrave visível, o conhecimento e familiaridade com as CPS, dada a sua recente inserção nos processos das compras governamentais. Assunto a ser abordado nas próximas seções. 


\subsubsection{Percepção dos Servidores do IFRO em relação às Compras Públicas Sustentáveis}

A dimensão abordada no questionário referente ao comportamento dos atores quanto à sustentabilidade ambiental será apresentada na sequência, e para facilitar a compreensão e apresentação das discussões, as variáveis relacionadas ao conhecimento com o tema sustentabilidade e CPS, interesse pela temática, participação em eventos e apoio às práticas que contribuem para a sustentabilidade, utilizou-se a análise fatorial.

No entanto, antes de efetuar a análise fatorial com as variáveis, convém destacar as medianas obtidas individualmente, apresentadas na Figura 4. Os menores valores representam menor grau de conhecimento, apoio e interesse e variaram de 1 a 5.

Comparando a variável sobre conhecimento com a temática sustentabilidade com a variável de conhecimento sobre CPS, verificou-se que a concentração das respostas da primeira, está entre as opções 2 e 4, com mediana 3, opção de (moderado), conforme a disposição do primeiro gráfico demonstrada na Figura 4.

Figura 4 - Variáveis submetidas à análise fatorial

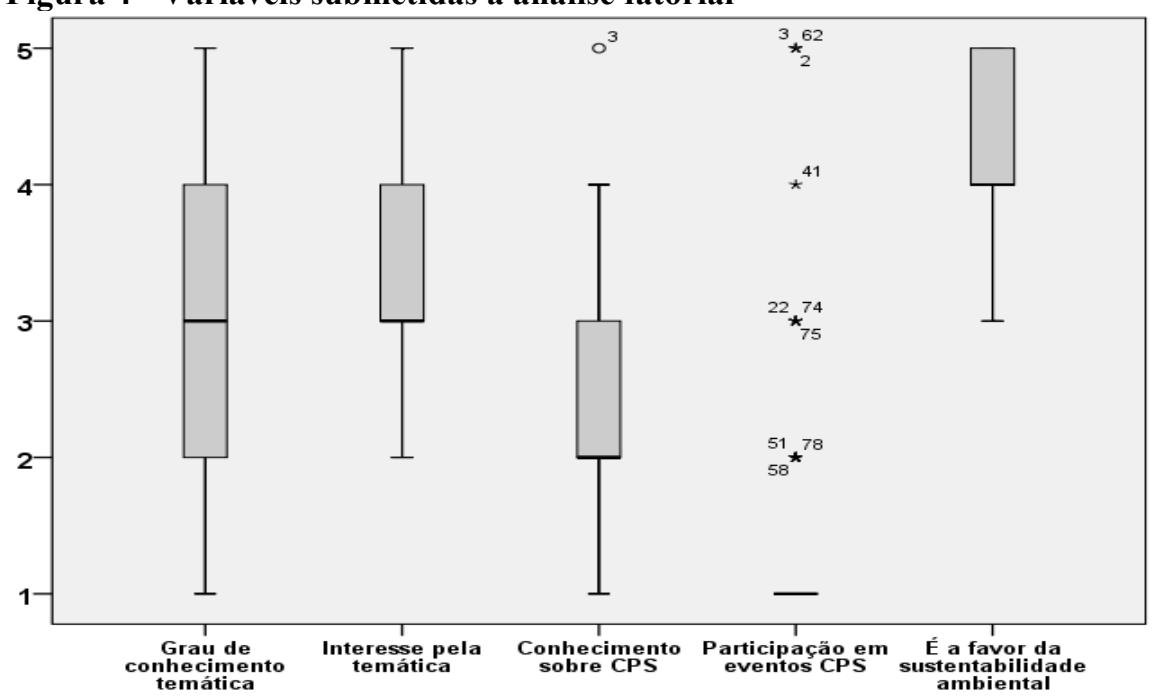

Fonte: Elaboração da autora

Quanto ao grau de conhecimento sobre as CPS, a concentração de 50\% das respostas ficou disposta entre os quartis dois e três, com a mediana na opção 2, correspondendo a (pouco conhecimento), portanto além de apresentar menor mediana, também não concentrou 
as mesmas opções de respostas, inclusive, havendo apenas uma indicação na opção 5, (conhecimento elevado).

Os dados revelaram que, mesmo havendo conhecimento moderado sobre a temática da sustentabilidade; o conhecimento sobre as CPS foi pouco, indicando com isso que, por mais que os servidores envolvidos nos processos de compras da Instituição tenham presenciado ou acompanhado a evolução dos assuntos sobre a temática da sustentabilidade no meio acadêmico ou veiculados na mídia; de maneira geral, não houve participações em treinamentos e demais capacitações relacionadas às CPS. Tal resultado pode ser confirmado pelas concentrações de respostas na mediana 1, opção de (nenhuma participação), demonstrado pela variável relacionada à participação em eventos.

A variável sobre o interesse pela temática apresentou mediana 3, demonstrando pelas respostas que há um moderado interesse, contudo quanto à demonstração se os servidores são favoráveis à sustentabilidade, a mediana das respostas ficou na opção 4 (elevada), com metade da concentração entre a opção elevada e muito elevada. Confirmando uma predisposição e aceitação às ações que favoreçam a sustentabilidade, porém sem, contudo, haver muito interesse em ações diretas que contribuem para tal prática.

\section{Análise Fatorial}

Para as variáveis iniciais desta dimensão do questionário: p1(grau de conhecimento sobre a temática sustentabilidade ambiental); p2 (interesse pelo assunto); p3 (conhecimento sobre as CPS); p4 (participação em eventos na área de CPS ou relacionada à temática sustentabilidade); e p5 (grau de concordância com as práticas que contribuem para diminuir impactos negativos ao meio ambiente) foi efetuada análise fatorial. Incorrendo primeiramente na verificação ao grau de correlação entre as variáveis, de acordo com Almeida (2010).

Foram considerados inicialmente os resultados obtidos da matriz anti-imagem para identificar o KMO individual que deveria estar acima de 0,50, para posteriormente analisar o 
KMO geral e dar prosseguimento à análise fatorial. O KMO individual foi satisfatório, haja vista que o menor valor apresentado foi de 0,733 , demonstrados na Tabela 5 , assim como o KMO geral, 0,752.

Tabela 5 - Matriz anti-imagem para identificação do KMO individual

\begin{tabular}{l|r|r|r|r|r}
\hline & \multicolumn{1}{|c|}{$\begin{array}{c}\text { Grau de } \\
\text { conhecimento } \\
\text { temática }\end{array}$} & $\begin{array}{c}\text { Interesse } \\
\text { pela } \\
\text { temática }\end{array}$ & $\begin{array}{c}\text { Conhecimento } \\
\text { sobre CPS }\end{array}$ & $\begin{array}{c}\text { Participação em } \\
\text { eventos CPS }\end{array}$ & $\begin{array}{c}\text { É a favor da } \\
\text { sustentabilidade } \\
\text { ambiental }\end{array}$ \\
\hline \multirow{3}{*}{$\begin{array}{l}\text { Correlação - } \\
\text { Matriz anti- }\end{array}$} & $\mathbf{7 4 4}$ &,- 360 &,- 383 &,- 112 &,- 053 \\
\cline { 2 - 6 } imagem &,- 360 &, $\mathbf{7 5 8}$ &,- 124 &,- 047 &,- 292 \\
\cline { 2 - 6 } &,- 383 &,- 124 &, $\mathbf{7 3 3}$ &,- 327 &, 071 \\
\hline
\end{tabular}

Nota: Medida de adequação da amostra em negrito, KMO acima de 0,5 Fonte: Elaboração da autora

Pelos valores apresentados, houve a possibilidade de continuar com a análise fatorial. A primeira análise foi rodada sem rotacionar e determinar o número dos fatores, obtendo o percentual de explicação em torno de $51 \%$, para apenas um fator, utilizando a opção do autovalor acima de um.

Sendo assim, na intenção de melhorar o percentual de variância, ou de explicação, foi efetuada nova análise com a rotação ortogonal de fatores. Após a rotação dos fatores pelo método Varimax, foi obtido um percentual de explicação aproximado de 70\%, levando em consideração a escolha de dois dos fatores apresentados pelo Gráfico Scree Plot, contido no Apêndice F. Que mesmo com o autovalor abaixo de um no segundo fator, a condição foi aceita, haja vista que houve aumento no poder de explicação, conforme demonstrado na Tabela 6: 
Tabela 6 - Total da variância explicada após a rotação ortogonal e determinação de fatores

\begin{tabular}{l} 
Fatores \\
\cline { 2 - 12 }
\end{tabular}

Na Tabela 7, estão dispostas as cargas fatoriais extraídas após a análise fatorial para cada variável, indicando que todas apresentaram valores satisfatórios acima de 0,5 para serem aceitas na análise fatorial.

Tabela 7 - Disposição das variáveis com os devidos valores das cargas fatoriais

\begin{tabular}{l|r|r}
\hline \multirow{2}{*}{ Variáveis } & \multicolumn{2}{|c}{ Número de fatores } \\
\cline { 2 - 3 } & \multicolumn{1}{c}{1} & \multicolumn{1}{c}{2} \\
\hline Conhecimento sobre CPS &, 872 & \\
\hline $\begin{array}{l}\text { Grau de conhecimento da } \\
\text { temática }\end{array}$ &, 780 & \\
\hline Participação em eventos CPS &, 690 & \\
\hline $\begin{array}{l}\text { É a favor da sustentabilidade } \\
\text { ambiental }\end{array}$ &, 532 &, 585 \\
\hline Interesse pela temática &
\end{tabular}

Fonte: Elaboração da autora

As medidas compostas foram formadas por meio de escalas múltiplas, de acordo com a mediana dos grupos de variáveis indicadas pelos resultados das análises fatoriais e, como meio para avaliar a consistência interna das variáveis envolvidas nos dois fatores, foi utilizado o valor do alpha de cronbach para cada grupo de variáveis.

Para o primeiro fator, obtido pelas variáveis, p1; p3 e p4, o valor do alpha de cronbach, foi de 0,730. Aplicando o mesmo para o segundo fator, o valor do alpha de cronbach foi de, 0,492, considerado inadmissível. Mas, segundo HAIR et al. (2005), na avaliação do alpha de cronbach deve ser considerada sua relação positiva com o número de variáveis na escala e, neste caso, possivelmente o valor abaixo tenha sido em razão de ser 
medido com apenas duas variáveis; por conseguinte foi assumida a limitação e considerada a escala para essas variáveis.

O primeiro fator, como englobou as variáveis referentes ao conhecimento e participação em eventos correlatos, foi chamado de familiaridade com as CPS. O segundo fator que agrupou as variáveis referentes ao interesse e apoio às CPS foi chamado de interesse e apoio às CPS. As medianas de ambas as variáveis estão dispostas na Figura 5.

Figura 5 - Familiaridade dos respondentes com as CPS e Interesse e apoio às CPS

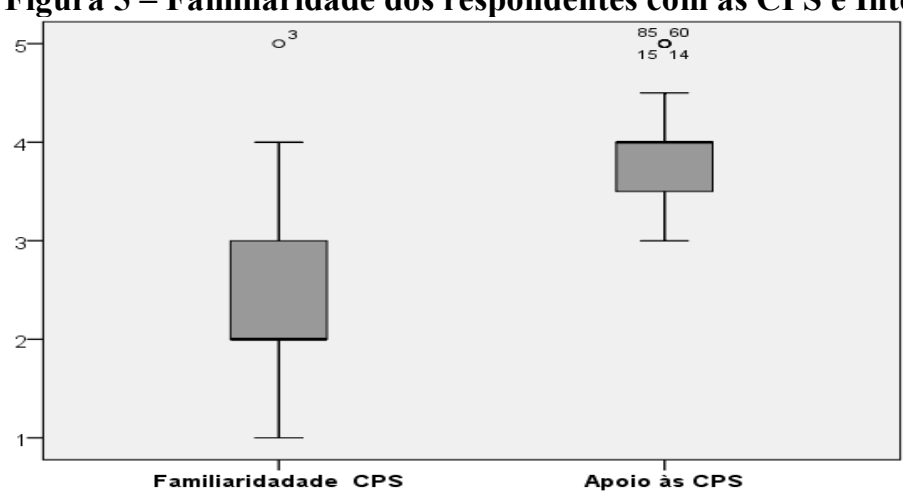

Fonte: Elaboração da autora

A familiaridade das CPS pelos servidores do IFRO obteve mediana 2, categorizada pela opção de (pouco conhecimento). A variável que mediu o grau de favorecimento com interesse e apoio apresentou mediana 4, (elevado interesse e apoio). Os números acima do gráfico que representou o apoio às CPS referem-se aos respondentes que indicaram o grau máximo de apoio e interesse. A importância de se investigar o fator conhecimento e familiaridade pode ser traduzida e confirmada por (BARKI; GONÇALVES-DIAS, 2014):

Há uma relação positivada expressa entre licitação e sustentabilidade e no estudo desta nova equação legal nas contratações públicas nacionais e das consequências administrativas que decorrerão percebe-se quão importante é o conhecimento jurídico sobre o que é, o que objetiva e como se contextualiza o desenvolvimento sustentável, daqui se destacando, novamente, a importância da capacitação e educação ambiental de servidores públicos. (BARKI; GONÇALVES-DIAS, 2014, p.15)

$\mathrm{Na}$ questão aberta de número seis, foi solicitado ao respondente que indicasse de acordo com seu conhecimento, algumas categorias de materiais e serviços passíveis de serem incluídos critérios sustentáveis no IFRO. Com um total de 63 respondentes, houve indicações 
de materiais de consumo, permanentes (equipamentos e veículos), serviços e obras, englobando todas as naturezas de contratações, (bens, serviços e obras) apresentados no Quadro 7.

Os materiais e serviços mais mencionados, os mais lembrados, foram também os mais licitados dentre os órgãos do poder público e os abrangidos pela Comissão Europeia, Alencastro; Silva e Lopes (2014); MPOG, (2014). São eles: papeis; materiais de expediente; insumos de tecnologia da informação (TI), principalmente, cartucho de tôner e tinta para impressora; materiais e serviços de limpeza; materiais de construção e equipamentos permanentes, como os de refrigeração, os relacionados à tecnologia da informação e os eletroeletrônicos.

Como eram esperados, os serviços não foram tão mencionados, já que a dimensão social é mais subjetiva de se atrelar valor, contudo ainda foram lembrados, demonstrando assim que há entendimento sobre quais materiais ou serviços podem ser inseridos critérios que fomentem o desenvolvimento nacional sustentável, peculiares à Instituição pesquisada.

Quadro 7 - Categorias de materiais e serviços passíveis de inclusão de critérios sustentáveis, apontadas pelos servidores do IFRO

\begin{tabular}{|l|l|l|l|}
\hline \multicolumn{1}{|c|}{$\begin{array}{c}\text { Categorias de serviços e } \\
\text { materiais }\end{array}$} & $\mathrm{N}^{\circ}$ Indicações & \multicolumn{1}{|c|}{ Categorias de serviços e materiais } & $\mathrm{N}^{\circ}$ Indicações \\
\hline Materiais de construção & 02 & Copos descartáveis & 07 \\
\hline Papeis & 18 & Materiais de expediente & 14 \\
\hline Material de limpeza & 07 & Embalagens & 05 \\
\hline Insumos de TI e impressões & 11 & Combustível & 04 \\
\hline Energia elétrica & 09 & $\begin{array}{l}\text { Equipamentos } \\
\text { eletroeletrônicos, TI, Solar) }\end{array}$ & 19 \\
\hline Defensivos agrícolas & 02 & Alimentícios & 05 \\
\hline Plásticos & 03 & Copa e cozinha & 01 \\
\hline Produtos veterinários & 01 & Pilhas e baterias & 01 \\
\hline Veículos & 05 & Obras & 07 \\
\hline Serviço de limpeza & 06 & Locação de mão de obra & 02 \\
\hline Font:Elabra & \\
\hline
\end{tabular}

Fonte: Elaboração da autora

Diante dos apontamentos, subentende-se que os servidores tanto conhecem os materiais e serviços passíveis de inclusão, como também conhecem os que estão ligados à demanda da Instituição. Para tanto, logo na próxima questão foi justamente solicitado que 
indicassem a frequência em que a inclusão de critérios sustentáveis descritos na questão anterior ocorre na Instituição.

$\mathrm{Na}$ Figura 6 foi ilustrada a frequência da inclusão de critérios sustentáveis das naturezas de materiais e serviços ora apresentados pelos respondentes na questão anterior. $\mathrm{O}$ total obtido de 68 respostas, distribuídas dentre as opções variaram de nunca, até sempre, em uma escala de cinco pontos; preponderou a mediana 3, codificada como a opção (às vezes).

O resultado caracterizou que, por mais que se conheçam algumas categorias de materiais e serviços, não são frequentemente incluídos critérios sustentáveis nas compras e contratações nos processos de compras do IFRO.

Figura 6 -Frequência da inclusão de critérios sustentáveis

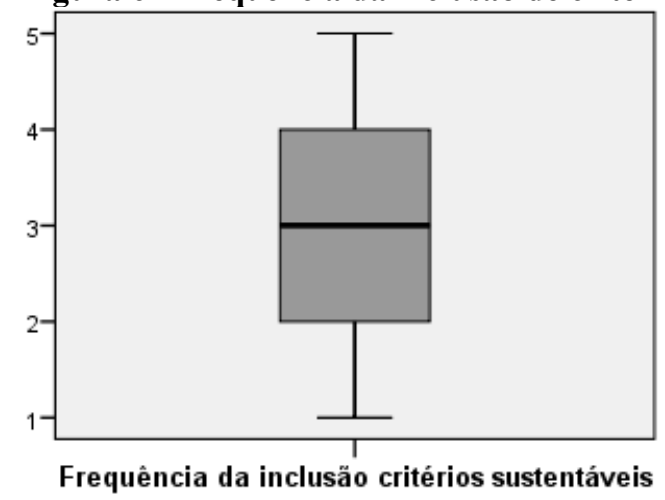

Fonte: Elaboração da autora

\section{Percepção dos respondentes quanto às dificuldades na implementação das CPS}

A questão número oito, de múltiplas respostas, com possibilidade de quatro indicações, apresentou um rol de nove opções fechadas e uma na condição de especificar, caso não estivesse dentre as demais, sobre os fatores relacionados às dificuldades na implementação e execução das CPS na Instituição.

Esta questão teve a intenção de levantar as dificuldades mais destacadas para posteriormente confrontá-las com as questões que mediram o grau de concordância ao que tange as dificuldades elencadas. Em outras palavras, de acordo com as respostas obtidas na questão oito foram analisadas as respostas das questões 09 a 17, no intuito de validá-las. 
Tabela 8 - Dificuldades apontadas pelos participantes da pesquisa frente às CPS

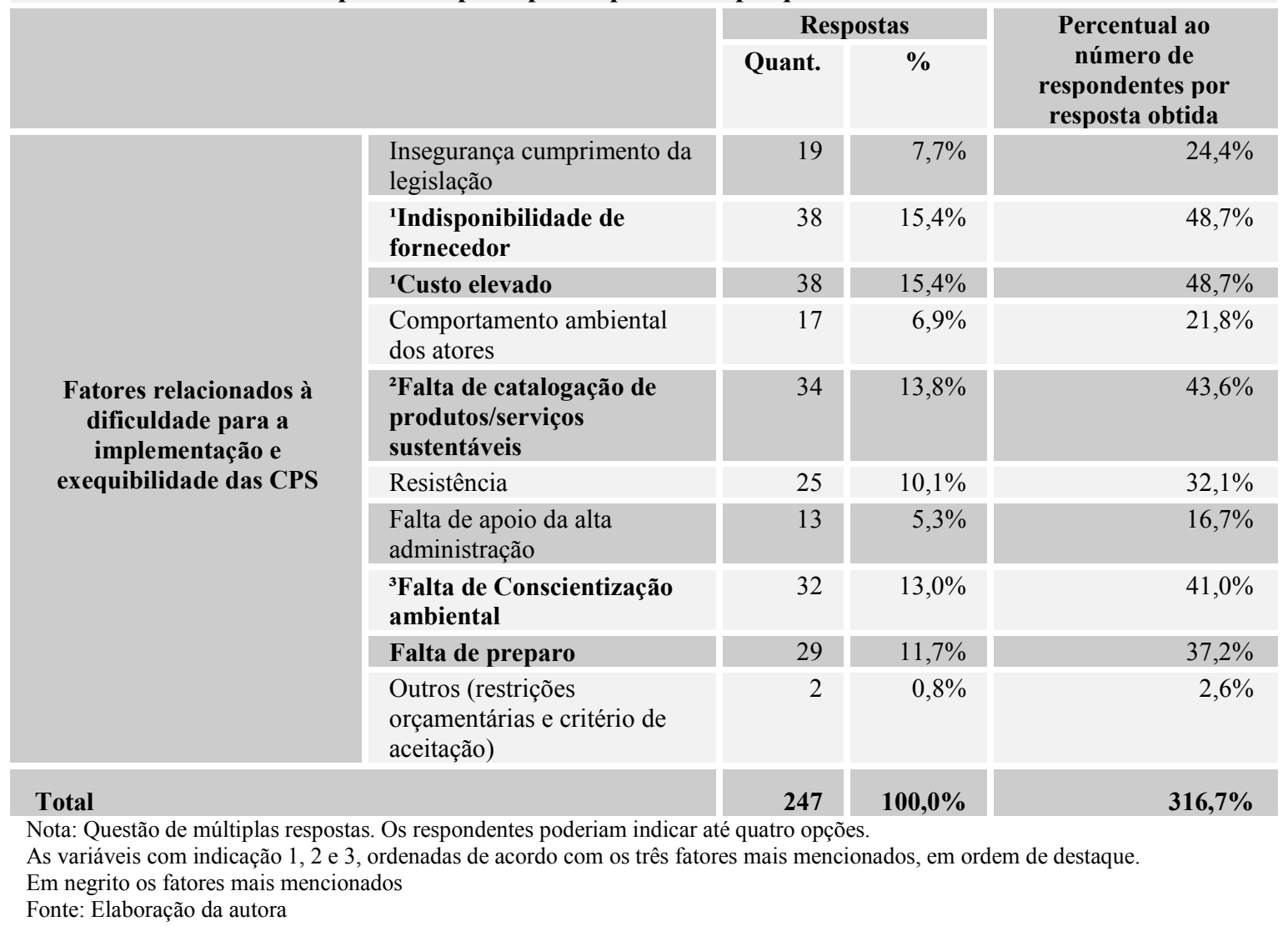

Para esta questão, houve a participação de $90 \%$ dos respondentes, o que correspondeu ao total de 247 respostas de acordo com a Tabela 8. As opções de indisponibilidade do fornecedor e o custo elevado das CPS foram ambas apontadas por aproximadamente $49 \%$ dos respondentes, com 38 registros cada. Foram as principais dificuldades registradas.

A próxima dificuldade mais registrada foi relacionada à falta de catalogação de produtos sustentáveis, com 34 respostas e 43,6\% dos respondentes, seguidas da indicação percebida como a falta de conscientização ambiental, com 32 respostas e a falta de preparo dos servidores na condução do processo relacionado às CPS, com 29 respostas, correspondendo há um pouco mais de $37 \%$ dos respondentes.

Diante do exposto, os resultados obtidos nesta questão corroboram com outras pesquisas de mesma natureza, Brammer e Walker (2011); Teixeira (2013); Bittencourt (2014), os quais constataram o fator custo como preponderante obstáculo para a tomada de decisão 
em favor das CPS, assim como a indisponibilidade de fornecedores que atendam aos critérios dessa natureza e a questão quanto à familiaridade com as CPS, que puderam ser caracterizadas pelas opções: falta de catalogação de produtos, conscientização ambiental e preparo dos servidores.

Brammer e Walker (2011) também deram destaque ao fator relacionado à falta de apoio da alta administração para o êxito das CPS, contudo no IFRO, vale destacar, foi a menor indicação atrelada à dificuldade mencionada pelos servidores respondentes, com apenas 13 respostas, dando indicações de que possivelmente a alta administração não seja considerada uma das maiores dificuldades percebidas na Instituição para a implementação das CPS.

Entretanto, a fim de melhor analisar esta abordagem relacionada ao apoio, constam outras variáveis de mesma natureza no questionário visando a uma confirmação entre as respostas para tal observação, tendo em vista a relevância apresentada no referencial teórico pelos pesquisadores da área.

Para tanto, a fim de verificar se há relação quanto à frequência da inclusão de critérios sustentáveis e o apoio da alta gestão no IFRO, efetuou-se análise de correlação entre as referidas variáveis, conforme Tabela 9.

Tabela 9 - Correlação entre as variáveis: Frequência da inserção de critérios sustentáveis e apoio da alta gestão

\begin{tabular}{|c|c|c|c|}
\hline \multicolumn{2}{|l|}{ VARIÁVEIS } & $\begin{array}{l}\text { Frequência da inclusão } \\
\text { critérios sustentáveis. }\end{array}$ & $\begin{array}{c}\text { A alta gestão da Instituição } \\
\text { apoia as ações voltadas às CPS }\end{array}$ \\
\hline \multirow{3}{*}{$\begin{array}{l}\text { Frequencia da inclusão critérios } \\
\text { sustentáveis. }\end{array}$} & $\begin{array}{l}\text { Correlação de } \\
\text { Pearson }\end{array}$ & 1 &, $442^{* *}$ \\
\hline & $\begin{array}{l}\text { Significância } \\
\text { (Bicaudal) }\end{array}$ & & ,000 \\
\hline & Número de casos & 68 & 67 \\
\hline \multirow{3}{*}{$\begin{array}{l}\text { A alta gestão da Instituição apoia } \\
\text { as ações voltadas às CPS }\end{array}$} & $\begin{array}{l}\text { Correlação de } \\
\text { Pearson }\end{array}$ &, $442^{* *}$ & 1 \\
\hline & $\begin{array}{l}\text { Significância } \\
\text { (Bicaudal) }\end{array}$ &, 000 & \\
\hline & Número de casos & 67 & 78 \\
\hline
\end{tabular}

Nota: ** Correlação significante ao nível de 1\% (bicaudal).

Fonte: Elaboração da autora 
Ao analisar a percepção dos servidores acerca da inclusão de critérios sustentáveis em materiais ou serviços nos processos licitatórios e a sua relação com o apoio da alta gestão, contatou-se que existe uma correlação linear $(0,442)$, considerada moderada, positiva significativa ao nível de $1 \%$. Demonstrando que as duas variáveis variam juntas, permitindo afirmar que há uma tendência em que a inclusão de critérios sustentáveis seja mais frequente, quanto maior for o apoio da alta gestão.

Como mencionado anteriormente, para verificação quanto aos constructos relacionados à identificação das dificuldades sob o ponto de vista dos servidores, foram dispostas questões com a intenção medir o grau de concordância das afirmações. Para cada opção oferecida na questão oito sobre o registro das dificuldades, foi apresentada uma afirmação para a indicação do grau de concordância, demonstradas na Figura 7.

Figura 7 - Grau de concordância sobre as dificuldades na implementação das CPS no IFRO

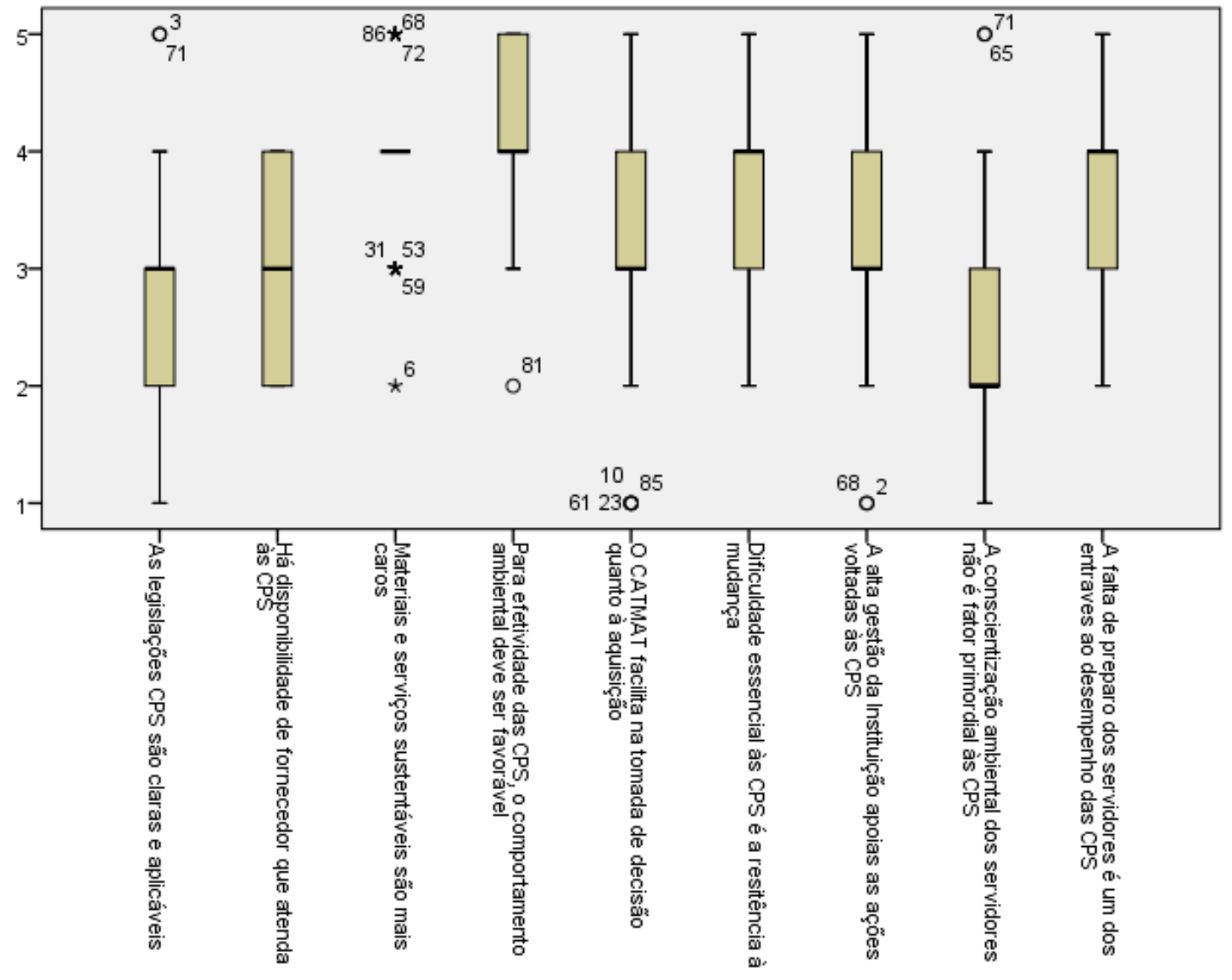


Em confirmação às questões levantadas quanto às dificuldades mais registradas: indisponibilidade do fornecedor; custo elevado dos produtos sustentáveis; falta de catalogação de produtos e serviços sustentáveis; conscientização ambiental dos servidores e falta de preparo dos servidores. Puderam ser confirmados pelas concordâncias, os fatores relacionados a dificuldades quanto ao custo elevado; a conscientização ambiental dos servidores e a falta de preparo dos servidores, apresentando medianas $(4,0),(2,0)$ e $(4,0)$ respectivamente, ou seja, correspondendo a opção (concordo), contidas na Figura 7.

Cumpre salientar que a afirmação relativa à dificuldade (a conscientização ambiental não é fator primordial na contribuição às CPS) tratou-se de uma afirmação invertida. Utilizada desta forma, para minimizar possíveis respostas desatentas, ou automáticas.

As demais variáveis destacadas pelos respondentes: há disponibilidade de fornecedor que atenda às CPS e, o catálogo de materiais (CATMAT) do sistema de compras como facilitador na tomada de decisão na aquisição, não puderam ser confirmadas em decorrência das respectivas afirmações, uma vez que elas apresentaram medianas 3, com respostas neutras, (nem concordo, nem discordo). Se trouxer para a análise a informação quanto ao nível de respostas em branco para estas afirmações, pode-se entender que as variáveis não foram percebidas pelos servidores, ou que não fazem parte da rotina do IFRO

Quanto ao aspecto referente à catalogação, pôde-se entender que, pelas respostas dos servidores, porventura não conhecem ou não utilizam o CATMAT para cadastramento ou consulta de item sustentáveis, ou ainda, porque, por mais que o CATMAT possa facilitar, ele atualmente não contribui em razão de haver poucos itens sustentáveis cadastrados, conforme Alencastro; Silva e Lopes (2014).

Foi também verificado o grau de concordância na opção neutra, referente à clareza e à aplicabilidade das legislações relacionadas às CPS. E na afirmação relacionada ao apoio da alta gestão, com concentrações nas respostas entre as opções 3 e 4 (nem concordo, nem 
discordo e, concordo), a sugestão é a mesma sobre a dificuldade sobre a catalogação dos produtos no CATMAT. Falta de percepção ou desconhecimento sobre a variável, pelos respondentes.

Em se tratando da clareza e aplicabilidade da legislação, Bryner (2010) ressalta que, em suma, os formuladores de políticas flexibilizam aos responsáveis pela implementação da lei a ajustar e tentar resolver os problemas por meio de tentativas e erros, aprendendo de acordo com a necessidade, porém muitas vezes essa clareza está ausente e, consequentemente ocorre uma sobrecarga aos administradores públicos.

No contexto da legislação das compras governamentais, os fluxos dos processos não podem ser modificados, incorrendo, portanto ao que cabe o poder discricionário dos servidores, o estabelecimento das políticas institucionais da gestão de compras, isto é, a forma como serão conduzidos os processos e os modelos de documentos que irão formalizá-los (BÚRIGO; MARTINS, 2015).

Mesmo não sendo apontadas pelos servidores, como as quatro dificuldades mais relevantes, em verificação ao grau de concordância das demais afirmações, cumpre mencionar as que indicaram medianas 4, (opção de concordo), são elas: para a efetividade das CPS, o comportamento ambiental deve ser favorável; e uma dificuldade essencial às CPS é a resistência à mudança. Estando em consonância com os achados de pesquisa contidos no referencial teórico, como sendo grandes empecilhos ao desempenho das CPS.

Os fatores que tiveram as afirmações com concordância, mediana 4, estão atrelados ao quesito conhecimento, familiaridade e comportamento pró-ativo dos atores em favor da sustentabilidade que, segundo Couto e Coelho (2015) podem ser trabalhados e introduzidos por meio de campanhas, normativas e treinamento, enfim políticas institucionalizadas transformadas em ações participativas.

Sobre o engajamento Betiol et al. (2012) afirmam que: 
Uma barreira é a falta de engajamento dos servidores, normalmente sob a alegação de haver impedimentos legais para o enfoque socioambiental nas licitações. No entanto, parcela importante deste poder de transformações está associada a ações voluntárias e à consciência ambiental e social de cada indivíduo - sejam gestores públicos ou empresariais, tomadores de decisão em diferentes níveis, formadores de opinião ou simplesmente consumidores (BETIOL et al, 2012, p.50).

A conscientização ambiental e preparo dos servidores, apontadas como fator de dificuldade, possivelmente possam estar relacionadas a capacitações e treinamentos e à própria cultura. No IFRO, as questões agrupadas na análise fatorial em relação a conhecimento e familiaridade, a mediana obtida para esse rol de questões, foi a 2, codificada como pouco conhecimento ou conhecimento superficial, indicando uma possível dificuldade dentro da Instituição.

A capacitação e sensibilização, mesmo sendo um fator determinante e estratégico para as CPS, pouco têm sido feito na Instituição para solucionar tais dificuldades. A responsabilidade inerente à participação em capacitações relacionadas às CPS pode ser compartilhada entre à administração e o próprio servidor, no caso do IFRO.

Cabe à administração a oferta de cursos na modalidade in company, contemplada anualmente no Plano Anual de Capacitação (PAC), com vistas a suprir a lacuna de treinamentos. Ao servidor cabe solicitar à comissão de capacitação sobre os cursos necessários ao bom desempenho e desenvolvimento de suas atribuições. O PAC possibilita o atendimento quando o curso pleiteado não estiver sendo ofertado à coletividade, condicionado à disponibilidade de recursos com capacitações externas. (IFRO, 2011a).

Para identificar os grupos em que a familiaridade é maior ou menor, foi dividido o arquivo de dados por setores de lotação dos servidores e analisada a questão em que o respondente indicou o grau de familiaridade com a temática da sustentabilidade ambiental e as CPS, com opções variando de nenhum a muito elevado. 
Figura 8 - Identificação do grau de familiaridade com as CPS por setor de lotação

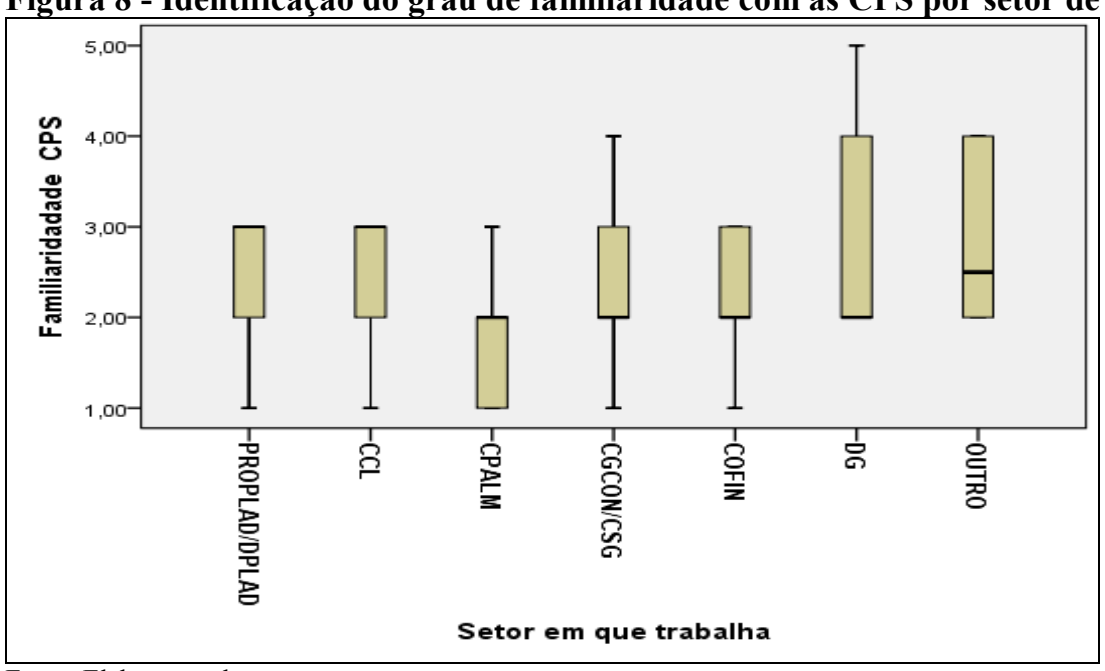

Fonte: Elaboração da autora

De acordo com a Figura 8, pode-se perceber três informações de destaque: a primeira é quanto a pouca familiaridade, representada pela mediana 2, aos servidores ligados à Coordenação de Patrimônio e Almoxarifado (CPALM), Coordenação de Gestão de Contratos (CGCON) e Coordenação de Serviços Gerais (CSG) que, nesta pesquisa se caracterizam principalmente por desempenharem a função de principais solicitantes de materiais, equipamentos e serviços. A CPALM pelos materiais e equipamentos e a CGCON/CSG pelos serviços.

Os servidores lotados nesses setores teriam condições de complementarem ou até mesmo induzirem outros servidores demandantes a incluírem critérios sustentáveis nas descrições das devidas solicitações, haja vista que, além de serem os responsáveis pela atribuição de receberem as solicitações desses setores demandantes, conforme informações coletadas no questionário, o contato com os demais setores é constante e direto. Dessa forma, apresentando um grande potencial para disseminação da inclusão de critérios sustentáveis nas compras do IFRO.

Supostamente, para a efetividade das CPS, os servidores responsáveis pela solicitação de materiais e serviços devem conhecer, além da demanda da Instituição, a cultura da organização e, ainda estar em sintonia com as possibilidades da inclusão de critérios que vão 
ao encontro da sustentabilidade para adquirir o bem ou contratar o serviço. Para isso, os servidores daqueles setores necessitam estar alinhados à política, bem como conhecer os critérios sustentáveis que possam ser adotados nas solicitações e como inseri-los.

A segunda informação a acrescentar é sobre o grau de familiaridade moderada, mediana 3, de acordo com as respostas dos servidores ligados ao planejamento PROPLAD/DPLAD. Que, de todo modo também é um influente setor ao que tange a inclusão de critérios sustentáveis, valendo-se da autonomia que detém por força da competência atribuída nas deliberações do que comprar, bem como em relação ao gerenciamento do orçamento anual da Instituição. Este setor responde conjuntamente com o ordenador de despesa e também recebem solicitações de serviços e materiais.

A terceira informação é justamente sobre a familiaridade mencionada pelos DiretoresGerais e a condição dada dos servidores lotados em outros setores. De acordo com os dados, os respondentes indicaram mediana menor que os servidores lotados na PROPLAD/DPLAD, porém com uma concentração de $50 \%$ das respostas, acima das demais, atingindo inclusive a opção de maior familiaridade, na opção 5, (muito elevada) e, nenhuma resposta com a opção 1, (nenhuma familiaridade).

Esta informação remete à possibilidade do apoio da alta gestão quanto à promoção de capacitação e treinamento, considerando que os servidores lotados nos setores que tiveram maiores graus de familiaridade/conhecimentos são também os responsáveis pela ordenação de despesa e implantação de política na Instituição, pois atuam diretamente no planejamento estratégico da organização.

Quanto aos que estão na condição de outros setores possivelmente podem contribuir na disseminação da política e comporem comissões ou comitês responsáveis pela institucionalização da política. Batista e Maldonado (2008) afirmam que o desempenho de um 
comprador se contempla por meio do acúmulo de conhecimento e capacitação, diferenciando o de um comprador reativo para um pró-ativo, por mais que seja um comprador público.

Em que as compras ocorrem seguindo ritos pré-estabelecidos a fim de salvaguardar o interesse público que está em jogo. Todavia, vale lembrar que todos servidores de certa forma estão na condição de solicitantes, pois de todo modo, as contratações públicas envolvem atores das diversas unidades da instituição (TEIXEIRA, 2013).

\section{Percepção dos fatores que cooperam para a promoção do desenvolvimento sustentável}

Após a apresentação das variáveis relacionadas às dificuldades percebidas pelos respondentes, foi solicitado aos servidores que também em escala ordinal de cinco pontos, indicassem o grau de concordância sobre os fatores que cooperam para as CPS, evidenciadas na Figura 9.

Figura 9 - Grau de concordância sobre fatores que cooperam para CPS

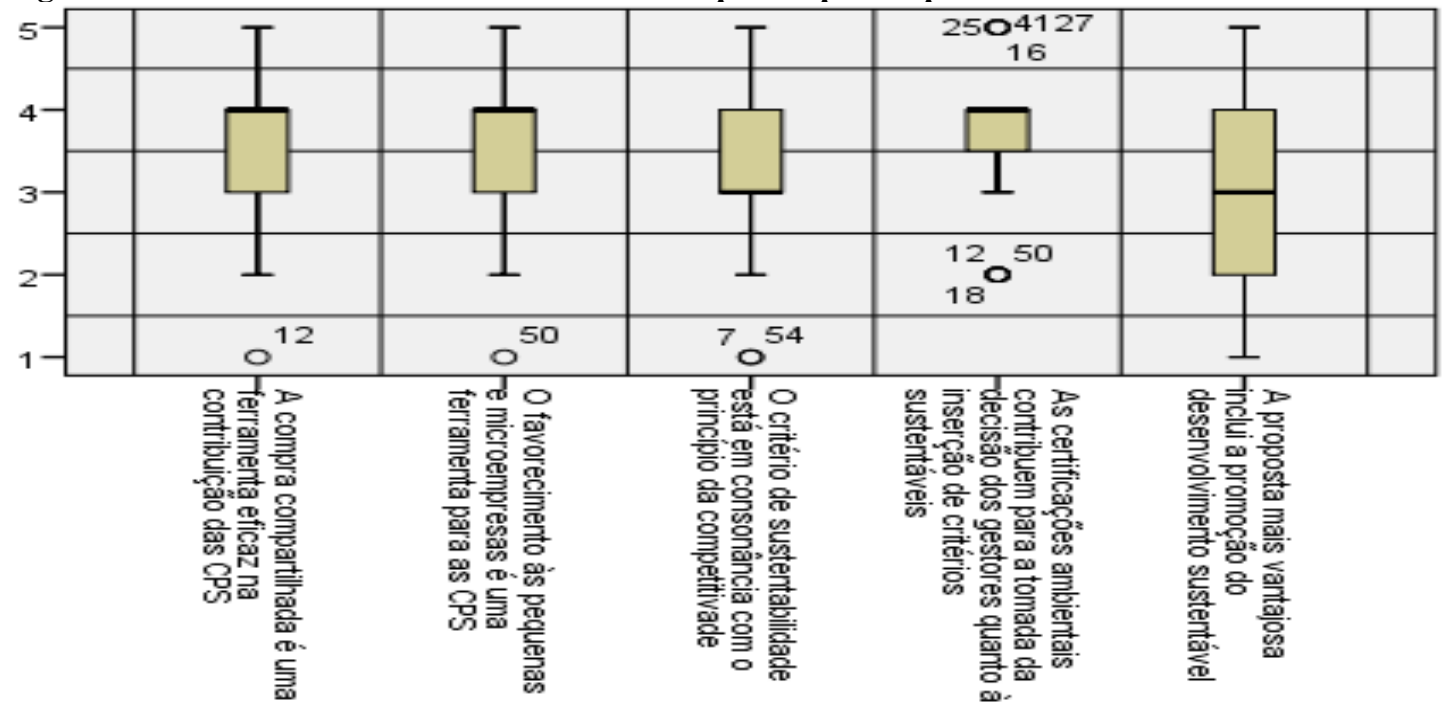

Fonte: Elaboração da autora

A compra compartilhada foi um fator amplamente discutido neste estudo, abordando duas das quatro dimensões do questionário, com um total de quatro questões. A fim de melhor esclarecimento, será apresentada juntamente com a dimensão relativa à rotina que envolve o processo de compras do IFRO.

Pode-se identificar na Figura 9, o grau de concordância dos respondentes sobre o conhecimento das ações que cooperam para as CPS, como compra compartilhada; o 
favorecimento às MPEs e o auxílio das certificações na tomada de decisão quanto à inserção de critérios sustentáveis, todas essas variáveis apresentaram mediana 4, opção de (concordo) com as afirmações.

De acordo com o referencial teórico, pode-se verificar que, por mais que os servidores dizem não dispor de uma familiaridade com as CPS, o entendimento sobre as ações a serem utilizadas nas compras que favorecem a sustentabilidade estão em consonância com as práticas adotadas por outras Instituições, relatadas pela literatura.

No entanto, sobre as afirmações se o critério de sustentabilidade está em acordo com a competitividade, ou seja, não interfere na ampla concorrência entre os fornecedores; e se a proposta mais vantajosa inclui o desenvolvimento sustentável, as respostas indicaram que há incerteza perante os servidores, haja vista que a concentração das respostas ficou na mediana 3, opção (nem concordo, nem discordo).

Trazendo o fator custo, por ter sido considerado um dos maiores impedimentos ao desempenho das CPS, para a análise dos fatores que apresentou mediana 3, a fim de verificar a percepção individualizada alta gestão, foi dividido o arquivo de dados com a separação dos setores e refeita a análise.

A alta gestão foi agrupada entre os cargos de diretores-gerais, pró-reitores e diretores administrativos. $\mathrm{O}$ resultado obtido foi praticamente o mesmo, a mediana para ambas as variáveis ficaram na opção neutra, (nem concordo, nem discordo), medianas 3,0 e 3,5, respectivamente, confirmando a mesma percepção dos demais servidores respondentes.

Com o resultado dessa análise, pode-se perceber que, como inclusive a alta gestão não tem definido o entendimento sobre a compra mais vantajosa e há dúvida quanto a ferir o princípio da competitividade com a utilização da CPS, fica possivelmente comprometida a predisposição a orientar os servidores quanto à inserção de critérios sustentáveis. E o fator 
custo fica mais preponderante a obstáculo, haja vista que não está atrelado o entendimento sobre o custo benefício da utilização das CPS.

Betiol et al. (2012) sobre o entendimento relacionado ao custo imediato entendido pelos servidores, deixam claro e defendem que não se caracteriza como anti-ético pagar mais caro por produtos ou serviços que tragam benefícios agregados, como ambientais e sociais, além do mais esses custos devem ser internalizados no valor monetário dos bens.

O MPOG (2015), por uma declaração publicada no portal de compras do governo, citando algumas razões para incluir critérios sustentáveis nas contratações públicas, no fator custo, explanou que:

Produtos, serviços e obras de menor impacto ambiental, ainda que tenham um maior custo aparente no momento da contratação, são mais econômicos no longo prazo. Isso porque reduzem os gastos do Estado com políticas de reparação de danos ambientais, têm maior durabilidade, menor consumo de energia e materiais, e incentivam o surgimento de novos mercados e empregos verdes, gerando renda e aumento de arrecadação tributária (MPOG, 2015).

Associando a questão sobre o apoio da alta gestão, por mais que não seja o fator de maior dificuldade observado pelos servidores do IFRO, também não haverá estímulo para praticar algo considerado incerto, podendo ser constatado pelas próximas questões que representaram o que ocorre com maior frequência nas contratações e sobre a orientação mais difundida em relação à solicitação de bens e serviços, contidas na dimensão da rotina envolvida no processo de compras.

O entendimento permeado sobre a participação das MPE nos processos de compras contribuindo para a prática das CPS; a proposta mais vantajosa com a inclusão de critérios sustentáveis e ainda o amparo da legislação que as CPS não ferem o princípio da competitividade, é defendido por vários autores (BITTENCOURT, 2014; TEIXEIRA, 2013; BETIOL et al., 2012; MOTTA; OLIVEIRA, 2015; COGO, 2015; BRAMMER; WALKER, 2011; SIVA; BARKI, 2012). 
A vantagem da participação das MPE foi apresentada no referencial teórico, assim como também a demonstração pelos autores ao que compete o entendimento da proposta mais vantajosa. Em se tratando da competitividade nas CPS, Bittencourt (2014) afirma que "se a definição de critérios, características e especificações concernentes ao objeto fundar-se em justificativa plausível e pertinente para a definição dos critérios de sustentabilidade, não representará em nenhum momento restrição ao princípio da competitividade".

Nesta dimensão do questionário pode-se perceber que os servidores têm noção sobre as CPS, contudo restam fatores ainda pouco conhecidos ou percebidos, tanto sobre as dificuldades, quanto às práticas já adotadas por outras instituições em favor da sustentabilidade nas compras.

Tais lacunas podem estar relacionadas a pouca familiaridade direcionada ao tema, ou ainda por não haver uma política institucionalizada, ou seja, conhecida pelos envolvidos, objeto de discussão das próximas abordagens.

A implementação de uma política pública e a adoção de práticas não convencionais gera uma mudança no modo de atuar e, sob este aspecto nesse cenário de incertezas, pode acarretar estagnação do processo de implementação pela falta de apoio e de segurança de como proceder (TEIXEIRA, 2013).

\subsubsection{Rotina Envolvida no Processo de Compras - Ações relacionadas às Compras Governamentais pelo IFRO}

A realização do diagnóstico é fundamental para que se possa planejar a implementação de ações voltadas para as CPS. Para tanto, procedeu-se o levantamento de práticas já estabelecidas no IFRO e o que vem sendo praticado referente aos processos de compras sustentáveis. 
Antes de entender como ocorre o processo de compras do IFRO, cabe primeiramente saber o que são os processos. Gonçalves (2000) se propôs a facilitar a compreensão em virtude de haver variedade de significados encontrados e que gera inúmeros mal-entendidos. O conceito, definições e aplicações oferecidas pelo autor sobre processo organizacional será o utilizado para este estudo.

Segundo Gonçalves (2000, p.7) “numa concepção mais frequente, processo é qualquer atividade ou conjunto de atividades que toma um input, adiciona valor a ele e fornece um output a um cliente específico". Sustentado por Malote et al., (1997 apud GONÇALVES, 2000), os processos podem ser entendidos "como produzir alguma coisa", e a forma como são feitas. Equivale dizer que a importância do emprego do conceito de processo aumenta à medida que as empresas trabalham com conteúdo cada vez mais intelectual, oferecendo produtos cada vez mais ricos em valores intangíveis.

O presente tópico buscou apresentar a atual dinâmica das contratações públicas na Instituição, destacando como as compras vêm se apresentando no IFRO. De acordo com os dados levantados no questionário, de documentos e da literatura intentou diagnosticar como está caracterizado o processo de compras governamentais na Instituição e verificar se está embutido a ideia de sustentabilidade nas compras, o conceito de sustentabilidade, bem como sua materialização.

De acordo com Nonato (2014, p.58) “analisar os processos de compras públicas é um meio de organizar, planejar e gerenciar os fluxos de institucionalização das ideias até a rotina do setor público, destacando as escolhas apresentadas aos compradores na execução e incorporação dos referidos procedimentos". 


\section{Compra Compartilhada}

Em se tratando da compra compartilhada, o questionário abordou o assunto em duas das quatro dimensões, quais sejam: o comportamento dos atores quanto à sustentabilidade ambiental, com a questão 18, deixada para ser discutida nesta seção, e na dimensão referente à rotina envolvida no processo de compras, com as questões 23,24 e 35 .

Na questão 18, o respondente deveria indicar o grau de concordância na afirmação que a compra compartilhada é uma ferramenta eficaz no processo de aquisição e que pode contribuir com as CPS. Nas questões 23 e 24, foi perguntado se são efetuadas as compras compartilhadas no IFRO e que se de acordo com a experiência do servidor, essas compras atendem às necessidades da Instituição, respectivamente. Já na questão 35, foram oferecidas dez opções aos respondentes e solicitado que indicassem até três fatores de maior destaque quando as licitações não ocorrem em tempo hábil e que, dentre as opções estavam as compras compartilhadas.

Os resultados obtidos na dimensão relacionada ao comportamento dos atores, com as respostas da questão 18, no total de 82 respostas, os respondentes que concordam, compreendendo também os que concordam totalmente que a compra compartilhada é uma ferramenta eficaz na contribuição das CPS, foram de $67 \%$.

Os resultados da dimensão sobre a rotina envolvida nos processo de compras, com a questão 23, (são efetuadas compras compartilhadas no IFRO), indicaram que as respostas das opções geralmente e sempre, passaram de $75 \%$, confirmando as informações declaradas pelos servidores quando da aplicação do questionário.

$\mathrm{Na}$ questão 24, os servidores demonstraram que nem sempre as compras compartilhadas atendem à Instituição, pois nesta opção apenas $5 \%$ dos respondentes assinalaram. Todavia, os que apontaram que geralmente atende foram mais de 53\%, 
demonstrando, portanto, que metade dos servidores entende que as compras compartilhadas auxiliam o processo de compras em geral do IFRO.

Por último, a questão 35 de múltiplas respostas, que tratou dos fatores que cooperam para o atraso das licitações, teve como resultado que, dos 66 respondentes, para um total de 198 respostas distribuídas dentre as opções. As quatro mais destacadas apresentadas em ordem decrescentes foram: falhas nas descrições dos produtos e serviços, com uma frequência de 44 respostas, correspondendo a 66,7\% dos respondentes. Em seguida foi a ausência de fornecedores interessados, com um total equivalente a 33 respostas e um percentual mencionado por $50 \%$ dos casos (Tabela 10 ).

O terceiro fator mais registrado foi a opção relacionada ao atraso na pesquisa de preço, este também muito salientado pelas comissões de compras e diretores de planejamento e administração, durante o período da observação participante. O último dos quatro, foi o relativo ás compras compartilhadas, com 25 respostas registradas, totalizando $37,9 \%$ dos respondentes.

Tabela 10 - Fatores que cooperam para o atraso nas licitações do IFRO, na percepção dos servidores

\begin{tabular}{|c|c|c|c|}
\hline \multirow[t]{2}{*}{ FATORES } & \multicolumn{2}{|c|}{ Respostas } & \multirow{2}{*}{$\begin{array}{l}\text { Percentual ao número de } \\
\text { respondentes por resposta } \\
\text { obtida }\end{array}$} \\
\hline & Número de Respostas & Percentual das respostas & \\
\hline Atraso na pesquisa de preço & 29 & $14,6 \%$ & $43,9 \%$ \\
\hline Falhas na descrição dos produtos e serviços & 44 & $22,2 \%$ & $66,7 \%$ \\
\hline Valores acima do estimado & 19 & $9,6 \%$ & $28,8 \%$ \\
\hline Ausência de fornecedor interessado & 33 & $16,7 \%$ & $50,0 \%$ \\
\hline Compras compartilhadas & 25 & $12,6 \%$ & $\mathbf{3 7 , 9 \%}$ \\
\hline Constantes alterações no decorrer do & 8 & $4,0 \%$ & $12,1 \%$ \\
\hline processo & 12 & $6,1 \%$ & $18,2 \%$ \\
\hline Morosidade na condução do processo & 19 & $9,6 \%$ & $28,8 \%$ \\
\hline $\begin{array}{l}\text { Falha no planejamento } \\
\text { Tempo de análise jurídica }\end{array}$ & 9 & $4,5 \%$ & $13,6 \%$ \\
\hline Total & 198 & $100,0 \%$ & $300,0 \%$ \\
\hline
\end{tabular}


Se associar a questão anterior, que retratou sobre o atendimento das compras compartilhadas, a esta que apontaram os atrasos nas compras, pode-se entender que, possivelmente seja um dos motivos pelos quais as compras compartilhadas, nem sempre atendem a Instituição, em razão do atraso.

As demais opções, também em ordem decrescente foram: falhas no planejamento e valores acima do estimado, com 19 respostas cada, equivalente a 28,8\% dos apontamentos pelos respondentes. Com 12 respostas, morosidade na condução dos processos; com 09 respostas, foi o tempo de análise jurídica e, com 08, a opção de constantes alterações no decorrer do processo, correspondendo a 18,2\%; 13,6\% e 12,1\% dos respondentes, respectivamente. Indicando que dentre os fatores propostos nas opções, com exceção (valores acima do estimado), todos se caracterizaram dentro do contexto operacional administrativo.

Na Instituição, a compra compartilhada é uma prática consolidada entre as unidades, contudo, um problema que foi apontado, sendo uma constante reclamação dentre os servidores, é a pouca agilidade, a dependência do órgão gerenciador e a falta da aquisição quando é deixado de licitar algum bem ou serviço.

O processo das compras compartilhadas em si é um processo mais demorado em razão da necessidade de aguardar as manifestações dos órgãos interessados, com suas devidas demandas devidamente descritas e revisadas, a fim de excluir itens com descrições semelhantes, que pode gerar duplicidade nas aquisições. Isso evidencia a possibilidade relacionada ao atraso nas licitações apontadas pelos servidores e o resultado da questão, quando mencionado que, nem sempre atende a Instituição.

A morosidade, conforme relato dos próprios servidores envolvidos, se dá muitas das vezes pela falta de compromisso dos órgãos interessados, ou por mau desempenho do órgão gerenciador. No entanto, quando há sucesso na compra, o benefício é o atendimento a um 
número maior de participantes com apenas uma licitação, inclusive com melhores valores em decorrência da quantidade concentrada por item, acarretada pelos órgãos participantes.

Neste mesmo entendimento, Silva e Barki (2012, p.169) apontaram em estudo sobre compras públicas compartilhadas, cujo resultado demonstrou que foi "possível realizar uma compra ambientalmente correta e economicamente eficiente, utilizando-se a experiência da compra compartilhada de produtos sustentáveis, realizada entre os órgãos públicos do Rio de Janeiro". Sendo um exemplo concreto da implantação do conceito de desenvolvimento sustentável nas compras públicas.

Diante dos resultados do questionário e dos relatos dos servidores, ficou evidenciado que as compras compartilhadas são praticadas pela Instituição e geralmente, atendem às necessidades, porém há que se melhorar a execução a fim de que tenha um retorno mais célere e com menos conflito, já que a interdependência desse tipo de compra é estendida a toda a Instituição. Se não ocorrer com um bom planejamento, prejudicam as atividades dos envolvidos.

\section{Orientação sobre inserção de critérios sustentáveis}

A fim de verificar o que é mais frequente nas contratações de bens e serviços no IFRO, e qual orientação é mais difundida sobre as descrições nas solicitações relacionadas à orientação quanto á inserção de critérios sustentáveis, foram propostos aos servidores que indicassem, conforme opções contidas na Figura 10, dispostas nos referidos gráficos a ocorrência das mesmas. 
Figura 10 - Frequência de situações mais recorrentes no IFRO

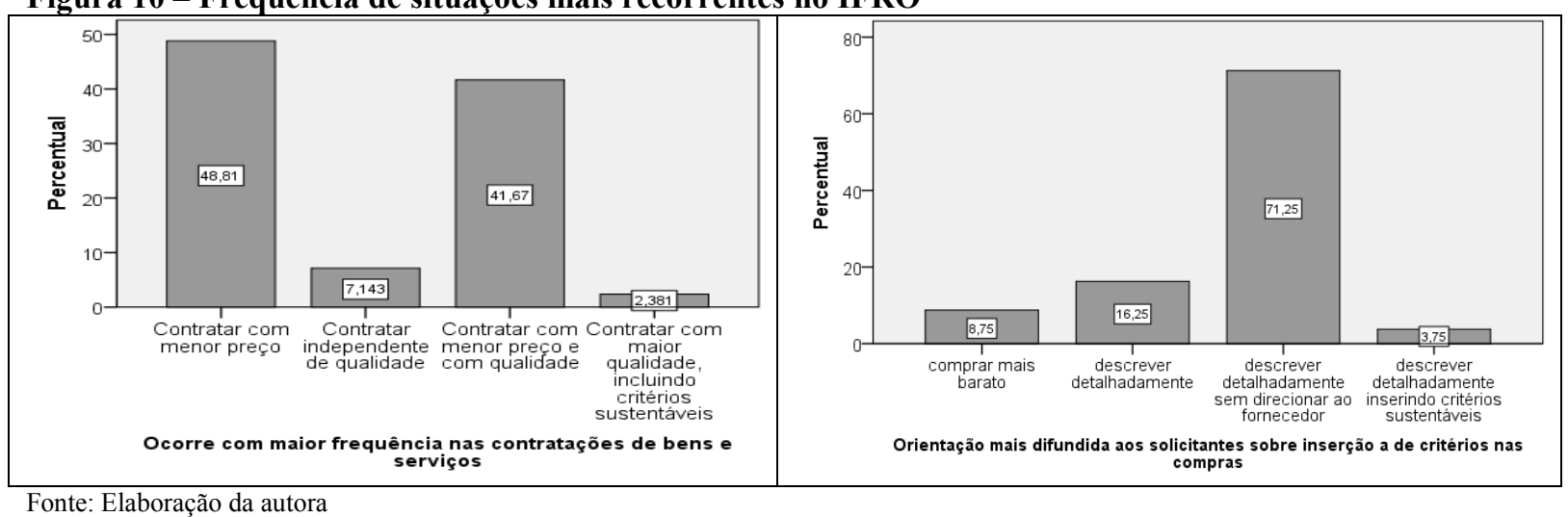

Perguntado ao servidor o que ocorre com maior frequência nas contratações de bens e serviços da Instituição, a concentração das respostas foi: contratar com o menor preço, 48,8\%, seguida da opção, contratar com o menor preço e com qualidade, 41,6\%. Ambas em detrimento da opção dada sobre contratar com inclusão de critérios sustentáveis que teve apenas 2,4\% das respostas. Equivale dizer que contratar com qualidade, incluindo critérios sustentáveis, não faz parte da rotina da Instituição ou não é percebida pelos servidores.

A outra questão pode explicar o resultado da primeira, a qual confirma a orientação repassada aos solicitantes de materiais e serviços. Quando perguntado qual orientação é mais difundida na Instituição sobre os critérios a serem estabelecidos para aquisição das compras governamentais, a opção oferecida sobre descrever detalhadamente, inserindo critérios sustentáveis, apresentou somente três respostas, de um total de 80.

Com as respostas representadas nos gráficos contidos na Figura 10, entende-se que, como a orientação sobre a inserção de critérios sustentáveis nas compras e contratações, praticamente não é difundida na Instituição, ou não alcançou os respondentes (segundo gráfico). Dessa realidade, entende-se consequentemente a constância sobre comprar com critérios sustentáveis também não ocorre com frequência (primeiro gráfico).

Ressalta-se que uma política a ser implementada tem maiores condições de êxito quando fomentada pelos servidores do nível estratégico, de cima pra baixo, tendo explicitado o apoio da alta gestão como forma de segurança e suporte. Sem desconsiderar outro fator de 
elevada necessidade que é a participação de todos durante a fase de implantação, a fim de proporcionar entendimento e comprometimento dos envolvidos no processo, como já discorrido no referencial teórico na Seção Dificuldades na Implementação da CPS.

A questão sobre o resultado da falta de disseminação de inserção de critérios sustentáveis nas compras do IFRO pode estar relacionado ao fator identificado acerca da incerteza no entendimento quanto à relação das CPS, com a proposta mais vantajosa, e que as CPS não interferem na competitividade entre os fornecedores. Contribuindo na insegurança de repassar orientação direcionada em favor das CPS.

Fazendo um paralelo sobre a percepção dos servidores em relação às dificuldades, os servidores apontaram na pesquisa que o apoio da alta gestão não representa um fator de dificuldade saliente, porém, se esse apoio não vier acompanhado de estímulo e cobrança, os demais envolvidos não sentirão segurança e possivelmente não se comprometerão com a mudança.

Segundo Brammer e Walker (2011), parte dos incentivos organizacionais depende da cultura organizacional e do grau em que a organização é favorável à sustentabilidade e/ou mudança, contudo, o fator da incerteza de como incorporar questões éticas e sociais que assegurem aplicabilidade através dos contratos também foram percebidos em seus estudos.

\section{Percepção dos servidores sobre as práticas rotineiras inerentes às compras}

No intuito de avaliar se há diferença estatística entre as percepções dos servidores dos Campi e Reitoria, a respeito de cada variável contida na dimensão sobre as práticas rotineiras nos processos de compras do IFRO, foi utilizado o teste $U$ de Mann Whitney, demonstrado na Tabela 11, juntamente com as medianas das respectivas variáveis. As opções de respostas foram dispostas em escala variando de um a cinco que, quanto mais próximo de cinco, mais frequentemente ocorre ou mais elevado é o grau de incidência. 
Diante dos resultados do teste $U$ pôde-se identificar que, em geral, a rotina envolvida no processo de compras do Instituto de Rondônia é semelhante. Sendo percebidas de igual maneira pelos servidores envolvidos, visto que não houve diferença estatisticamente significativa dentre as variáveis, pelos Campi e Reitoria. Com exceção da variável que abordou a aquisição de gêneros alimentícios orgânicos e/ou advindos da agricultura familiar.

Tabela 11 - Comparativo das medianas das respostas relacionadas à rotina envolvida no processo de compras do IFRO, com os resultados do teste de Mann-Whitney

\begin{tabular}{|c|c|c|c|c|}
\hline \multirow{2}{*}{\multicolumn{2}{|c|}{ QUESTÕES }} & \multicolumn{2}{|c|}{ MEDIANAS } & \multirow{3}{*}{$\begin{array}{l}\text { NÍVEL DE } \\
\text { SIGNIFICÂNCIA\% } \\
35\end{array}$} \\
\hline & & \multirow{2}{*}{\begin{tabular}{r|} 
Reitoria \\
2 \\
\end{tabular}} & \multirow{2}{*}{\begin{tabular}{r|r|} 
Campus \\
3 \\
\end{tabular}} & \\
\hline 27) & *As empresas locais e regionais são priorizadas na licitação? & & & \\
\hline 28) & $\begin{array}{l}\text { As solicitações dos materiais a serem licitados são descritas pelos setores } \\
\text { demandantes de forma precisa e completa? }\end{array}$ & 3 & 3 & 82 \\
\hline 34) & Há uma integração entre os setores envolvidos nos processos de compras & 3 & 3,5 & 65 \\
\hline 36) & Há uma fiscalização efetiva para o recebimento dos materiais? & 4 & 4 & 36 \\
\hline 38) & $\begin{array}{l}\text { * Nas contratações de obras e serviços é priorizado o emprego da mão de } \\
\text { obra de origem local }\end{array}$ & 3 & 4 & 36 \\
\hline 39) & $\begin{array}{l}\text { Há solicitação de material ou serviço com a inclusão de critérios sustentáveis } \\
\text { nos processos licitatórios, mesmo que não seja um edital específico de } \\
\text { compras sustentáveis? }\end{array}$ & 3 & 3 & 8 \\
\hline 40) & $\begin{array}{l}\text { *A legislação estabelece que sejam priorizados em certas compras, } \\
\text { fornecedores de pequena e microempresa. Em que grau é possível o } \\
\text { cumprimento desta legislação na Instituição? }\end{array}$ & 3,5 & 3 & 41 \\
\hline 41) & $\begin{array}{l}\text { *São adquiridos pela Instituição materiais que tenham critérios relacionados } \\
\text { ao menor número de embalagem em sua aquisição? }\end{array}$ & 3 & 2 & 11 \\
\hline 42) & $\begin{array}{l}\text { *Há prioridade na compra por produtos que permitam o uso de refil na } \\
\text { Instituição? }\end{array}$ & 2 & 2 & 79 \\
\hline 43) & $\begin{array}{l}\text { *Que prioridade é dada à aquisição de materiais reciclados ou recicláveis nas } \\
\text { contratações? }\end{array}$ & 2 & 2 & 66 \\
\hline 44) & $\begin{array}{l}\text { *Em aquisição de gêneros alimentícios, há solicitação de alimentos } \\
\text { orgânicos ou de agricultura familiar? }\end{array}$ & 2 & 1 & $1^{1}$ \\
\hline 45) & $\begin{array}{l}\text { *Em aquisições de equipamentos permanentes, é considerado algum critério } \\
\text { de eficiência energética, menor consumo de água ou maior durabilidade }\end{array}$ & 4 & 4 & 79 \\
\hline
\end{tabular}

Nota: 1- Valores estatisticamente significativos a $1 \%$ *Questões referentes a inserção de critérios sustentáveis nas compras públicas Fonte: Elaboração da autora

De acordo com os resultados apresentados na Tabela 11, quanto ao diagnóstico das compras públicas do IFRO, seguem também as análises em conjunto com as questões não ordenadas em escala.

Uma das práticas aplicadas pela gestão pública que contribui para a sustentabilidade nas compras é a prioridade dada às empresas locais e regionais nas licitações, no intuito de 
fomentar e expandir o comércio. A questão 27 do questionário abordou essa prática com o intuito de verificar qual a frequência nas licitações do IFRO.

Dentre as respostas obtidas, tanto dos servidores da Reitoria quanto dos campi, as medianas foi 2 e 3, respectivamente. Isso significa que não é uma prática rotineira, embora tanto a legislação da Instrução Normativa $n^{0}$ 1, de janeiro de 2010 , quanto à própria Lei 8.666/93, ampararem a prioridade.

Neste aspecto, o questionário levantou também sobre onde estão localizados os fornecedores com maiores problemas relacionados à entrega de materiais. Apresentando um percentual de 80,8 por cento das respostas, os servidores responderam que os maiores problemas ocorrem com fornecedores de outras regiões. O que desperta o interesse a questão sobre o porquê não priorizar os fornecedores locais e regionais, pois além de proporcionar melhoria na economia local ou regional, minimizaria o problema com as entregas, face, possivelmente pela logística em razão da localização do Estado de Rondônia.

A questão 28 teve a intenção de identificar se as descrições relacionadas às solicitações de materiais pelos setores demandantes são apresentadas de forma precisa e completa. A resposta mais apontada pelos servidores apresentou mediana 3, com a opção de (às vezes), portanto indicando que também não pertence à rotina das compras no IFRO, as descrições bem feitas.

A observação sobre falhas na descrição foi alertada por Erdmenger (2003 apud TEIXEIRA, 2013), considerando que os compradores públicos têm facilidade na conversão das informações recebidas para uma linguagem contratual, porém não são experts na definição de especificações. Portanto, a necessidade de uma descrição bem feita pelo solicitante é algo essencial ao êxito das compras governamentais. Se aplicada às CPS, essa atividade se torna ainda mais criteriosa devido à especificidade técnica. 
Problemas com a descrição na solicitação podem consequentemente incorrer em aquisições de materiais divergentes ao que foi solicitado, até mesmo podendo não ser adquirido, ou provocar atraso nas licitações, como apontado pelos respondentes sobre um dos atrasos na licitação.

Sobre a necessidade de se atentar para a descrição do bem ou serviço a ser licitado, Cogo (2015) argumenta que:

\begin{abstract}
A descrição bem detalhada do produto é fundamental para a aquisição de bens de qualidade, adequados às necessidades da instituição e com boa oferta de preço. A falta de correspondência entre as expectativas do solicitante e a descrição do objeto constante na requisição resulta na aquisição de bens que não correspondem às expectativas. Isso ocorre, aparentemente, porque o solicitante tende a conceituar mais e definir menos o objeto pretendido (COGO, 2015, p.31).
\end{abstract}

Outra importância identificada relacionada à necessidade da descrição precisa e completa no âmbito do IFRO foi quando perguntado aos servidores a respeito de quais procedimentos são adotados pelo setor de compras para adquirir produtos de melhor qualidade. Das 49 respostas obtidas foram relatados os procedimentos como: testes dos produtos; contratar com fornecedores de bons históricos de serviços (empresas idôneas) e solicitação de amostras.

Entretanto, $69 \%$ disseram que o procedimento adotado é a descrição clara e detalhada do bem a ser licitado. Entendida, assim, a importância de uma boa especificação nas solicitações, dada a sua dependência para a aquisição.

Quanto à percepção dos respondentes sobre a integração dos setores envolvidos nos processos de compras e contratações no IFRO, a mediana para ambas as unidades analisadas, foram 3,0 e 3,5, apontando que há uma integração entre os setores de forma moderada, o que possivelmente facilita uma participação na disseminação e entrosamento de atribuições direcionadas às CPS, se bem conduzida. 
A próxima questão a ser apresentada e discutida diz respeito se há na Instituição uma fiscalização efetiva para o recebimento de materiais. Das respostas registradas, a mediana 4 preponderou entre as opções, constatando que há geralmente uma fiscalização efetiva para o recebimento dos materiais comprados pelo IFRO. Desse modo, pode-se ter um acompanhamento da real entrega do material licitado, concretizando todo o empenho durante o processo de aquisição e contratação, ou seja, contribuindo para garantir o que foi pleiteado.

Diante das respostas apresentadas na Tabela 11, relativas às contratações de obras e serviços do IFRO, a opção (geralmente) foi registrada pelos Campi, quanto ao emprego da mão de obra de origem local, contemplando a mediana 4 e, na Reitoria, a opção (às vezes) pela mediana 3, porém como não houve diferença estatística entre as opções, não se caracterizou distinção entre as unidades.

Se comparada à questão que abordou sobre a mesma condição, porém aplicada à compra de materiais, pôde-se observar que com a contratação de serviços há maior incidência no cumprimento da prática de priorizar a região. Confirmando a percepção dos servidores, em consulta aos processos de serviços terceirizados no período da observação participante, foi constatado que as principais empresas prestadoras de serviços terceirizados no IFRO, como locação de mão de obra, serviço de conservação e limpeza e vigilância, são de Rondônia ou da Região Norte.

Quanto à solicitação da indicação pelos servidores sobre a maior demanda de serviços do IFRO, ficou evidenciada que é atendida tanto por fornecedores de Rondônia quanto por outras regiões, com 45,6\% em cada uma das opções. Apontando que o setor de serviços do Estado tem atendido à necessidade da Instituição, e com isso logo a contratação de serviços têm se concentrado no Estado e na Região, quando possível, conforme demonstrado nas análises dos processos e na percepção dos servidores. 
Segundo Bittencourt (2014, p.151) a função social do contrato administrativo, tanto de material quanto de serviços, constantes no conceito de sustentabilidade, admite sem hesitação a promoção do emprego local, pois "possibilita o aumento local de circulação de riquezas, fortalece o empreendedorismo, incrementa os pequenos negócios, gera o crescimento da economia, potencializa o número de postos de trabalho e reduz as desigualdades sociais".

Uma questão considerada, na averiguação da percepção dos servidores sobre a aplicação das CPS, foi a questão que solicitou que os respondentes indicassem relativa inserção de critérios sustentáveis nas licitações de serviços e materiais, mesmo que não fosse um edital específico de compras sustentáveis. A mediana das respostas para a questão foi a 3, opção de (às vezes) que, confrontada a informação com outras fontes de evidência, verificouse que realmente não é uma constante a prática de aquisição de material e serviços com inclusão de critérios sustentáveis.

Em análise aos editais de licitação do IFRO, contidos no portal eletrônico da Instituição e no portal de compras do governo federal, constatou-se que tanto materiais quanto serviços são incluídos critérios sustentáveis, mesmo que não seja de forma padronizada entre os campi, nem tampouco frequentes. Por outro lado, foram identificadas as categorias, como material de expediente, limpeza, insumos de impressão, papel, tôner, cartuchos e equipamentos.

Quanto aos serviços, além dos constantes nas obrigatoriedades como: proibição de trabalho noturno, perigoso ou insalubre a menores de dezoito anos, bem como proibição de emprego de menores de dezesseis, salvo na condição de menor aprendiz (Brasil, 1999). Foram encontrados critérios solicitando que os terceirizados tenham treinamento quanto à economia de água e energia, utilização de equipamentos de proteção individual (EPI) e para a manutenção de serviços de limpeza, que sejam utilizados produtos biodegradáveis. 
Alencastro; Silva e Lopes (2014), em análise aos dados extraídos do portal de compras do governo, revelaram que quase metade dos itens adquiridos no período de janeiro de 2010 a julho de 2012 foi composto por um único produto: cartucho de tinta reciclado. No entanto em 2014, segundo informações do MPOG (2014), os materiais mais adquiridos nesse exercício foram: papel A4; aparelho de ar condicionado; microcomputador pessoal (notebook); automóvel e detergente.

Os apontamentos quanto aos itens mencionados condizem com os mais diversificados e cadastrados no CATMAT, indicando uma possível dificuldade a ser levantada sobre a baixa diversidade de outros itens não catalogados. Implicando que, quanto maior for a catalogação de itens sustentáveis no CATMAT, mais facilitará a inclusão de itens sustentáveis nas licitações, haja vista que não seria necessário um maior empenho dos servidores ligados à área de compras, na busca por itens não catalogados, motivando a falta de interesse.

Estudo sobre o comportamento do gestor público responsável por compras sustentáveis, efetuado por Couto e Coelho (2015), demonstrou que os gestores não evitam a especificação de produtos que contenham critérios sustentáveis, mesmo cientes de que seus preços de mercado sejam usualmente superiores, desde que haja disponibilidade de recursos financeiros para isso.

O resultado desse estudo confirma também as respostas obtidas nesta pesquisa, na dimensão anterior que abordou o comportamento dos atores. O grau de apoio às práticas que contribuem para diminuir o impacto negativo do meio ambiente, em conjunto com a questão relacionada ao interesse pelo assunto, atribuiu mediana 4, implicando no entendimento que mesmo quando considerados mais dispendiosos, os servidores do IFRO são favoráveis.

Diante dessa realidade, é justo afirmar que o maior entrave no IFRO seja possivelmente a falta de inserção de critérios sustentáveis nos materiais e serviços, advindos 
pela falta de orientação e comprometimento com a Política Nacional de Desenvolvimento Sustentável.

A prática da inserção de critérios sustentáveis nas licitações públicas brasileiras, segundo Teixeira (2013), concorre com outras prioridades:

\begin{abstract}
Por não ser obrigatória, a prática de CPS concorre com outras prioridades e esbarra na resistência cultural dos gestores públicos e, conforme constatado por meio dos questionários aplicados, o desinteresse dos servidores envolvidos é um fator determinante. Portanto, caso o comprador público não seja estimulado, cobrado e orientado, os resultados de programas de CPS não serão satisfatórios (TEIXEIRA, 2013, p.219).
\end{abstract}

No entanto, Bittencourt (2014), baseado na afirmação de Garcia (2012), entende que é dever dos gestores públicos, mediante a ordem constitucional e na legislação ordinária, a implementação das licitações e contratações sustentáveis.

Porém, como no IFRO foi apontado que não é uma constante a precisão e clareza nas especificações, dificulta a efetividade das compras como um todo, principalmente as CPS que dependem de um maior empenho quanto aos critérios a serem inseridos. Diante dessa consideração, as condições de se efetuarem compras e contratações de serviços com especificações sustentáveis, ficam comprometidas.

A questão que mensurou em que grau é possível cumprir a legislação que beneficia às MPEs obteve a mediana 3,0 e 3,5, tanto a apresentada pela Reitoria como pelo Campus, respectivamente, representando grau moderado.

Em geral, foi observada a elevada participação das MPEs. No período de 2011 a março de 2016, dos valores despendidos, R\$ 274,02 milhões, 64,53\%, incluídos nessa análise, materiais, serviços e obras, atenderam às MPES. Perfazendo um montante de R\$176,83 milhões em benefício dessas categorias de empresas (MPOG, 2016). 
Do total do valor aplicado com aquisição de materiais (R\$ 162, 92 milhões), R\$ 109,44 milhões foram destinados às MPEs e, quanto aos serviços, dos R \$ 111,09 milhões, R\$ 67,38 milhões.

No interesse de verificar se o IFRO está adotando critérios sustentáveis nas licitações, a questão 41 contemplou questionamento específico sobre a inclusão de critério sustentável quanto ao menor número de embalagens nas aquisições dos produtos. As 77 respostas válidas indicaram pelas medianas 3 e 2, Reitoria e Campus, que é raro ou nunca, a aquisição de produtos com essa característica.

Outro critério constante a ser adotado nas CPS é referente à compra de produtos que permitam o uso de refil. Diante da mediana 2, das respostas obtidas, ficou entendido que poucas vezes é dado prioridade na aquisição com essa preocupação. O mesmo resultado foi também identificado quanto à prioridade sobre a aquisição de materiais reciclados ou recicláveis nas contratações. Em consulta aos editais de licitações foram constatados que se levados em consideração o que é contratado com produtos tradicionais, a proporção dos sustentáveis é irrisória.

Segundo Barki e Gonçalves-Dias (2014), essas três últimas questões mencionadas sobre as aquisições de produtos constam como objetivos da Política Nacional de Resíduos Sólidos a serem priorizadas por meio das compras governamentais.

Foi inserida uma questão relacionada à aquisição de gêneros alimentícios com a intenção de verificar se o IFRO adquire alimentos orgânicos ou provenientes da agricultura familiar. A Instituição fornece alimentação aos discentes, principalmente para o atendimento dos contemplados em regime de internato. Isso o credencia a ser classificado como órgão comprador, de acordo com a legislação correlata ao Programa de Aquisição de Alimentos. 
Diante da informação coletada nessa questão, houve uma diferença estatística implicando que a Reitoria raramente adquire gêneros alimentícios orgânicos ou advindos da agricultura familiar, mediana 2, enquanto que os Campi com mediana 1, nunca adquirem. Esses dados deixam subentendido que essa prática de compra sustentável também não faz parte da rotina da Instituição, por mais que os campi que ofertam regime de internato se encaixem na condição de fornecedor de alimentos.

O IFRO dispõe de características que, se direcionadas às práticas sustentáveis para aquisição de alimentos podem ser atendidas, segundo proposto por Martinelli et al. (2015). A primeira delas é em função de apresentar no quadro de servidores, profissionais na área de nutrição, o que resulta, portanto em competência técnica para efetivar a solicitação de gêneros alimentícios em favor da agricultura familiar.

A segunda característica identificada são os alimentos básicos demandados pela Instituição serem os geralmente fornecidos pela agricultura familiar, a qual é considerada a base da produção.

Outra característica é o montante aplicado, em média de R\$ 1,3 milhões/ano. Se efetivada a compra de produtos da agricultura familiar, pelo menos $30 \%$, culminariam uma contribuição de R\$ 390 mil reais na renda e no comércio local ou regional e, ainda contribuiria para manter o pequeno produtor no campo, haja vista que $26,45 \%$, da população rondoniense estão concentradas na zona rural.

Segundo Martinelli et al. (2015), para que haja sucesso da articulação entre a produção familiar e a compra institucional são necessárias novas formas de planejamento da produção e do processamento dos alimentos, assim como a organização do processo produtivo de refeições, com o envolvimento e a ação articulada dos diversos agentes. Dentre as estratégias apresentadas pela autora estão o mapeamento da produção local para inseri-los no cardápio e a realização de estudos para identificar a demanda. 
A última questão da Tabela 11 indicou a frequência na rotina do processo de compras em aquisições de equipamentos permanentes que considere algum critério de eficiência energética, ou menor consumo de água ou maior durabilidade. Nesta questão, o resultado foi geralmente, mediana 4, logo o IFRO considera em suas aquisições de equipamentos algum critério sustentável. Portanto, de acordo com a percepção dos respondentes, há geralmente aquisições de equipamentos com algum critério sustentável embutido na solicitação.

Para fins de informação ao que concerne o critério ora apresentado, em agosto de 2014 entrou em vigor a Instrução Normativa $\mathrm{n}^{\mathrm{o}} 2$, tornando obrigatória a Etiqueta Nacional de Conservação de Energia com classificação A (mais econômica), para as edificações públicas federais. Complementando as normativas atreladas ao desenvolvimento nacional sustentável. A norma estabelece as regras para a aquisição ou locação de máquinas e aparelhos consumidores de energia e o uso da Etiqueta Nacional de Conservação de Energia (Ence) nos projetos e edificações do governo federal.

As questões relacionadas à rotina que envolve o processo de compras da Instituição até aqui tratadas, tiveram a pretensão de verificar como ocorrem as compras de um modo geral na Instituição. Como ainda, verificar se práticas de inclusão de critérios sustentáveis são inseridas nas aquisições e contratações de serviços.

Porém, diante dos dados levantados pelo questionário e demais fontes de evidência, puderam ser consideradas como rotina favorável: a utilização das compras compartilhadas; a priorização do emprego de mão de obra local na contratação de obras e serviços; o atendimento ao benefício às MPEs e as aquisições de equipamentos permanentes com inserção de critérios que consideram a eficiência energética, menor consumo de água e maior durabilidade. 
No entanto, os critérios como prioridade às empresas locais e regionais nas licitações para aquisição de materiais; orientação sobre a inserção de critérios sustentáveis; a aquisição de materiais com menor número de embalagens, produtos que permitam o uso de refil; materiais reciclados ou recicláveis e a aquisição de gêneros alimentícios advindo da agricultura orgânica ou da agricultura familiar não puderam indicar uma rotina favorável às CPS pela Instituição.

Em suma, a dimensão quanto à rotina envolvida no processo de compras evidenciouse que há uma trajetória sendo desenvolvida convergindo para a adoção de compras sustentáveis, contudo a fim de aprimorar o processo de compras e prepará-lo para a implementação das CPS, há que se efetuarem algumas alterações. Pelas respostas semelhantes, foi percebido que há uma padronização no processo de compras, pelo menos quanto à percepção dos servidores.

\subsubsection{Cultura Organizacional e de Sustentabilidade: identificação de ações que fomentam a Política de Desenvolvimento Sustentável no IFRO}

A última dimensão do questionário aplicado aos servidores do IFRO foi sobre a cultura organizacional da Instituição dentro da perspectiva da sustentabilidade. Para a análise da variável cultura organizacional frente à sustentabilidade, utilizaram-se dados levantados além do questionário, também documentais, a fim de comparar a percepção dos respondentes

e às políticas identificadas por meio das normativas, verificando com isso a institucionalização das mesmas.

Viegas e Cabral (2015) apontam que, considerando as especificidades das Instituições, públicas ou privadas, quanto à responsabilidade pela construção do conhecimento científico e ainda pela atuação social e política na sociedade, é relevante perguntar como estão sendo tratadas as questões socioambientais em suas atividades, tanto às de meio quanto às de fim. 
Com os dados levantados na questão 46 do questionário, demonstrados na Tabela 12, em que as opções foram apresentadas com múltiplas respostas, o intuito foi verificar se há na Instituição ações sendo praticadas com a finalidade de estimular e incentivar as CPS. Foram disponibilizadas na questão, seis opções de respostas, em que o respondente poderia se fosse o caso, registrar todas elas, porém, não foi dada a opção da condição a nenhuma das ações.

Pela leitura feita nesta questão, evidenciou-se que $31 \%$ das respostas obtidas, distribuídas dentre as opções, não considerando o número de respondentes, mas sim o número de respostas, 113 no total, apontou que há outra política, devidamente formalizada, relacionada à sustentabilidade ambiental, como redução do uso de energia elétrica, água, combustível, impressões, papel; reciclagem de lixo ou conscientização quanto ao desperdício.

Na última coluna da Tabela 12, foi demonstrada a relação da análise, em razão do número de respondentes, que nesta ótica, evidenciou que quase 54\% dos respondentes concordam que há alguma ação que fomente às CPS.

Outra ação no mesmo nível de apontamento, ou seja, 31\%, registrou que a Instituição mantém anualmente eventos no calendário escolar que envolvem a temática de sustentabilidade ambiental. A próxima ação, referentes às respostas indicando se há preocupação dos gestores em relação às aquisições e contratações de produtos e serviços que causem menor impacto negativo ao meio ambiente, obteve percentual de $23 \%$, das 113 respostas no total, mencionados por $40,1 \%$ dos respondentes. 
Tabela 12 - Respostas apontadas pelos servidores sobre ações praticadas pela Instituição que fomentam as CPS.

\begin{tabular}{|c|c|c|c|}
\hline Ações praticadas pela Instituição em contribuição às CPS & $\mathrm{N}^{\mathrm{o}}$ Respostas & Percentual & $\begin{array}{l}\text { Percentual ao número de } \\
\text { respondentes por resposta } \\
\text { obtida }\end{array}$ \\
\hline Há outra política além da CPS sendo desenvolvida no IFRO & 35 & $31,0 \%$ & $53,8 \%$ \\
\hline $\begin{array}{l}\text { O IFRO mantém anualmente eventos que envolvem a temática } \\
\text { da sustentabilidade ambiental }\end{array}$ & 35 & $31,0 \%$ & $53,8 \%$ \\
\hline $\begin{array}{l}\text { São disseminados assuntos relacionados à sustentabilidade } \\
\text { ambiental regularmente entre a comunidade interna do IFRO }\end{array}$ & 16 & $14,1 \%$ & $24,6 \%$ \\
\hline $\begin{array}{l}\text { Proporciona capacitações sobre a gestão ambiental para os } \\
\text { servidores a fim de estimular a inserção de critérios } \\
\text { sustentáveis nas licitações }\end{array}$ & 0 & $0,0 \%$ & $1,5 \%$ \\
\hline Existe e é difundido o Plano de Logística Sustentável & 1 & $0,9 \%$ & $0,0 \%$ \\
\hline $\begin{array}{l}\text { Há preocupação dos gestores em relação às aquisições e } \\
\text { contratações que causem menor impacto negativo ao meio } \\
\text { ambiente }\end{array}$ & 26 & $23,0 \%$ & $40,1 \%$ \\
\hline TOTAL & 113 & $100,0 \%$ & $173,8 \%$ \\
\hline
\end{tabular}

Nota: a.Questão agrupada por ser de múltiplas respostas

Nota: b. Respostas de 65 respondentes, o equivalente a $75 \%$ dos questionários aplicados

Fonte: Elaboração da autora

Em geral, nesta análise, foi possível levantar informações baseadas nas percepções dos servidores, que o IFRO dispõe de ações que fomentem a sustentabilidade ambiental, porém não é percebida por toda comunidade. Isso se nota que somente em média $50 \%$ dos respondentes registraram a opção que representou que há outra política de sustentabilidade ambiental devidamente formalizada por meio de normativas e outros documentos.

No entanto, na busca por evidências documentais, essas normativas foram consideradas internas por unidade de lotação, já que não foi encontrada uma política institucionalizada para toda a Instituição, regulamentada e conhecida pelos pares. O que ocorre são ações por campus e pela própria Reitoria, porém não com um caráter de política propriamente dita.

Embora alguns campi e Reitoria disponham de normativas internas, por Portarias, restritas à própria unidade, como uso racional de energia, monitoramento do consumo de água, contudo não foi identificado que seja comum a todas as unidades, atuando de forma isolada. 
Outra evidência percebida foi sobre a manutenção de um calendário anual do IFRO, repassado a todos os campi, ou seja, de conhecimento da comunidade interna, que são inseridos e promovidos eventos que tratam da sustentabilidade, como a Semana Agroambiental, Semana de Educação para Vida e Semana Nacional da Ciência e Tecnologia. Além do calendário do IFRO, os campi também dispõem de eventos promovidos por suas próprias unidades, com caráter de disseminação do tema sustentabilidade.

Quanto à regular disseminação da temática da sustentabilidade entre a comunidade interna da Instituição, o resultado foi que $14,1 \%$ das respostas registraram esta opção. Insinuando que possivelmente não ocorrem, ou ocorrem esporadicamente, logo não é alcançada por todos.

Outra ação relevante, confirmada pela falta de familiaridade com as CPS, foi em relação à verificação se são proporcionadas capacitações sobre a gestão ambiental para os servidores, a fim de estimular a inserção de critérios sustentáveis nas licitações, porém para essa opção não houve indicação.

O mesmo ocorreu com a opção relacionada ao Plano de Gestão de Logística Sustentável (PLS), uma ferramenta de planejamento obrigatória a ser elaborada por toda a Administração Pública. Esse plano tem como propósito definir ações, metas, prazos de execução e mecanismos de monitoramento e avaliação, a fim de permitir ao órgão ou entidade em estabelecer práticas de sustentabilidade e racionalização de gastos e processos, conforme Decreto $\mathrm{n}^{\circ} 7.746 / 2012$.

Para essa opção, o resultado apontou apenas uma indicação. Diante disso, há evidência que, se o plano foi elaborado pela Instituição, é desconhecido pelos servidores envolvidos no processo de compras do IFRO. Não foi identificada sua divulgação, nos meios de comunicação do IFRO. 
A opção que verificou se há preocupação dos gestores em relação às aquisições e contratações que causem menor impacto negativo ao meio ambiente, sendo inclusive mais uma questão que tinha a intenção em identificar o apoio da alta gestão às CPS, resultou em percentual de $40,1 \%$ de registro pelos respondentes com $23 \%$ do total das respostas. Indicando que menos da metade dos respondentes afirmaram que há preocupação pelos gestores.

Diante dessas informações, pode-se entender que, mesmo que haja ações no intuito de estimular e incentivar as CPS, tais informações não estão alcançando todos os servidores, já que a percepção apenas atingiu a faixa de $50 \%$ dos envolvidos.

$\mathrm{Na}$ intenção de verificar a percepção dos servidores de cada unidade de lotação, Campus e Reitoria separadamente, para essa mesma variável, que representou as ações praticadas pela Instituição, foi efetuada uma divisão do arquivo dos dados, constantes no Apêndice D.

\section{Percepção dos servidores separados por unidade de lotação}

A separação dos dados das respostas teve características distintas da análise quando agregadas anteriormente, principalmente as referentes à questão que retratou sobre a prática de outra política de sustentabilidade ambiental que fomentasse às CPS. Esta questão teve maior saliência quando analisadas todas as unidades em conjunto. Já quando separadas, os campi Colorado do Oeste e Ariquemes, ambos agrícolas, tiveram os menores percentuais, e para o Campus Vilhena, não houve nenhum registro para esta opção.

Todavia estes mesmos campi deram destaque para a opção sobre manter anualmente eventos no calendário escolar que envolvesse sobre a temática de sustentabilidade ambiental, passando de 50\% nos campi Vilhena e Colorado do Oeste. 
O Campus Ariquemes e o de Ji-Paraná foram os únicos que ficaram acima de $30 \%$ quanto à preocupação dos gestores referente às CPS e, apenas a Reitoria teve uma indicação na relacionada à existência e se é difundido na Instituição o Plano de Logística Sustentável.

Em relação à capacitação, nenhuma das respostas registradas indicou que a Instituição constantemente proporciona treinamentos sobre a gestão ambiental, com a finalidade de estimular os envolvidos na especificação de produtos e serviços com a inclusão de critérios sustentáveis em suas solicitações. Isso confirma a informação levantada na dimensão do questionário sobre a rotina envolvida no processo de compras do IFRO, segundo a qual atestou que não há orientação quanto à inserção de critérios sustentáveis, tampouco capacitação e treinamento para que isso ocorra.

Brammer e Walker (2011) já contemplaram tal impedimento às CPS, relacionado aos incentivos organizacionais, ao afirmar que essa ação depende da cultura organizacional e do grau em que a organização é favorável à sustentabilidade e/ou a mudança. Essa afirmação auxilia a interpretação da questão ora discutida.

Sendo assim, diante dos resultados de ambas as análises, tanto das respostas dos servidores, quanto dos apontamentos de Brammer e Walker (2011), tal questão caracteriza e recai possivelmente sobre a cultura organizacional e o apoio da alta gestão nos processos estruturais.

"Embora muitas instituições possam ter a sustentabilidade em sua agenda, as dificuldades de lidar com um conceito transversal e multifacetado podem levar a não aplicação desses princípios na prática.” (TEIXEIRA, 2013, p.56).

\section{Responsabilidade por questões ambientais}

Este estudo também investigou se, dentro do IFRO, há algum servidor ou setor responsável especificamente pelas questões ambientais, caso a resposta fosse positiva que 
indicasse a função ou o cargo. Diante dos apontamentos de $87 \%$ dos respondentes, pode-se afirmar que não há.

Quanto ao dado supracitado, 15,7\% dos registros variaram indicando que tal atribuição é desempenhada pelos setores e comissões: com seis indicações para as Diretorias de Planejamento e Administração; três para Comissões instituídas para este fim; uma para o Departamento de Pesquisa e Pós-Graduação e outra para a Pró-Reitoria de Desenvolvimento Institucional. Diante dos dados levantados, não há um setor específico padronizado em todo o IFRO, nem um servidor com competência específica na Instituição para o atendimento relacionado à questão ambiental.

A próxima questão referiu-se ao fato: caso não houvesse um setor ou responsável, quem ou qual setor desempenharia a referida atribuição. Dada as respostas, dentre os 27 respondentes, as mais mencionadas foram: oito respostas para as Diretorias de Planejamento e Administração; três para as Diretorias de Produção (setor contemplado somente nos campi agrícolas); cinco indicações para professores das áreas afins; oito para as Coordenações de Serviços Gerais; três para Comissões instituídas; uma para Coordenação de Almoxarifado e Patrimônio e uma para a Diretoria de Desenvolvimento de Ensino.

Mediante as observações das respostas, ficou subentendido que não há, portanto, um setor com atribuição específica, tampouco um responsável. Em outras palavras, tanto na questão que solicitou que fossem mencionados os setores específicos para desempenharem as atribuições relacionadas à gestão ambiental quanto, à questão sobre o caso de não constar um setor ou responsável específico, quem ou qual setor ficaria com a incumbência, todos praticamente apontaram os mesmos setores. 


\section{Orientação sobre a Legislação atrelada às CPS}

Por último foi questionado se no âmbito jurídico do IFRO, a Procuradoria Jurídica (PROJUR), há orientação clara e concisa sobre como deve ser cumprida a legislação inerente às CPS. Segundo os respondentes, as opções de elevada e muito elevada, alcançaram um percentual de um pouco mais de $14 \%$.

Neste quesito, em análise aos processos licitatórios no período da observação participante, os pareceres continham orientações indicando quais as legislações deveriam ser observadas para o devido cumprimento da política nacional de desenvolvimento sustentável, como a Lei 147, de 07 de agosto de 2014, que versa sobre a participação exclusiva de MPE em licitações com valor até $\mathrm{R} \$ 80.000,00$ (oitenta mil reais).

Dentre as outras legislações, constantes no parecer, referentes à sustentabilidade, estão a própria Constituição Federal; os Compromissos Internacionais; a Política Nacional sobre Mudança do Clima, (Lei 12.187/2009 e o Decreto 7.404/2010), que regulamenta a referida lei; a Lei 12.305/2010 que rege sobre a Política Nacional de Resíduos Sólidos e estabelece dentre outras determinações, as aquisições de bens, serviços e obras a serem considerados critérios compatíveis com padrões de consumo social e ambientalmente sustentáveis, bem como dá prioridade para a aquisição produtos reciclados e recicláveis; e, finalizando, a Instrução Normativa $n^{\circ} 01 / 2010$, que trata das especificações para aquisição de bens, serviços e obras que deverão conter critérios de sustentabilidade ambiental.

Sendo assim, diante da legislação abordada no parecer da PROJUR, constatou-se que as principais legislações atreladas às CPS são mencionadas e sugeridas para serem aplicadas nas licitações, de acordo com sua especificidade. Todavia, não foram analisadas a clareza ou as peculiaridades sobre as orientações, a não ser as constantes nos pareceres. 
Ainda em relação às análises dos processos, foi identificado que no Termo de Referência são mencionados os artigos referentes à IN 01/2010 quanto ao cumprimento da legislação pelo fornecedor. Por outro lado, de acordo com informações dos servidores, tais observações não são verificadas.

Contudo não foi identificado no IFRO normativas quanto aos procedimentos relacionados às CPS, além das orientações emanadas pelos pareceres jurídicos, ou seja, não há uma política institucionalizada que cooperem com as compras sustentáveis. Diante dessa liberdade, "quando os fins da organização e das políticas são imprecisos, o desempenho como um todo e o do agente não são fáceis de serem aferidos. Torna-se difícil monitorar os atores a partir de seu desempenho quando os critérios de sucesso são obscuros" (OLIVEIRA, 2012).

\section{Aceitação das CPS}

Em se tratando da aceitação das CPS, sob o ponto de vista pessoal e organizacional, mediante respostas de 84 servidores para ambas as questões, ficou demonstrado que a pessoal atingiu mediana 4, categorizada como opção elevada e concentrando em 50 por cento das respostas entre as opções 3 e 4, (moderada a elevada). Entretanto o grau de aceitação das CPS pela Instituição teve a mediana 3, categorizada como moderada, e concentração de 50 por cento das respostas entre as opções 2 e 4, (pouca a elevada), havendo, portanto maior dispersão (Figura 11).

Figura 11 - Grau de aceitação das CPS na perspectiva pessoal e organizacional

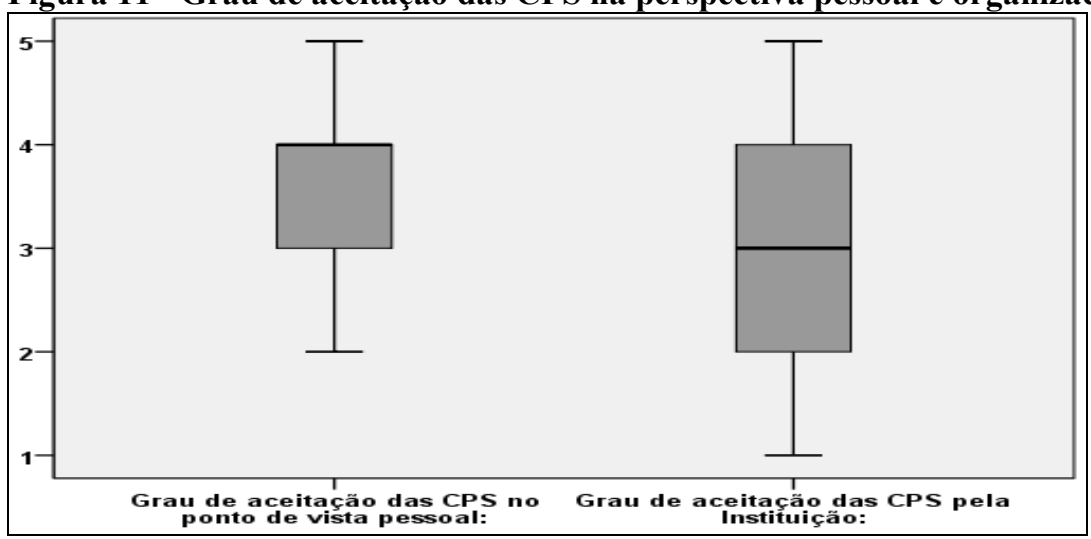

Fonte: Elaboração da autora 
Relacionando a variável responsável pela medição do grau de aceitação das CPS pela Instituição e a frequência em que ocorre a inclusão de critérios sustentáveis nas compras do IFRO, (variável 39), obteve-se uma correlação linear positiva, de 0,433, ao nível de 1\%, considerada moderada, demonstrada na Tabela 13. Essa informação sugere que, conforme o grau de aceitação das CPS pela Instituição aumenta, também aumenta a frequência da inclusão de critérios sustentáveis nas compras.

Tabela 13 - Resultado da análise de correlação linear das variáveis: Grau de aceitação das CPS pela Instituição e Frequência da inclusão de critérios sustentáveis

\begin{tabular}{|c|c|c|c|}
\hline \multicolumn{2}{|l|}{ Análise de Correlação } & $\begin{array}{l}\text { Indique o grau de } \\
\text { aceitação das CPS } \\
\text { pela Instituição: }\end{array}$ & $\begin{array}{c}\text { Frequência da } \\
\text { inclusão critérios } \\
\text { sustentáveis }\end{array}$ \\
\hline \multirow{3}{*}{$\begin{array}{l}\text { Indique o grau de aceitação das } \\
\text { CPS pela Instituição: }\end{array}$} & Correlação de Pearson & 1 & $433^{* *}$ \\
\hline & Significância (Bicaudal) & & ,000 \\
\hline & Número de casos & 84 & 68 \\
\hline \multirow{3}{*}{$\begin{array}{l}\text { Frequencia da inclusão critérios } \\
\text { sust. }\end{array}$} & Correlação de Pearson & $433^{* *}$ & 1 \\
\hline & Significância (Bicaudal) &, 000 & \\
\hline & Número de casos & 68 & 68 \\
\hline
\end{tabular}

**. Correlação significante ao nível de ,001 (bicaudal).

Fonte: Elaboração da autora

\section{Sustentabilidade nas normativas internas do IFRO}

$\mathrm{Na}$ intenção de analisar a cultura organizacional do IFRO, foram buscadas informações sobre a natureza, as finalidades, os princípios, os objetivos e suas características, bem como a organização administrativa da Instituição, contidas nos documentos que a regem, quais sejam: o Estatuto e Regimento Geral, Resoluções do Conselho Superior; Atos da Reitoria e dos demais órgãos componentes de sua estrutura administrativa.

E ainda aos documentos consoantes ao planejamento, como o PDI, com o propósito de verificar se está inseridas a temática da sustentabilidade e como a Instituição, vem lidando com a política nacional de desenvolvimento sustentável. A justificativa da análise dessa documentação foi em razão de subsidiar uma possível leitura da importância da sustentabilidade refletida na materialização das normativas contidas na organização, conforme apresentados no Quadro 8, os relacionados ao Estatuto. 
Quadro 8 - Identificação das abordagens referentes à sustentabilidade no Estatuto do IFRO

\begin{tabular}{|c|c|c|}
\hline \multicolumn{3}{|c|}{ Do Estatuto } \\
\hline Princípios norteadores: & $\begin{array}{l}\text { I. } \\
\text { II. } \\
\text { III. } \\
\text { IV. } \\
\text { V. }\end{array}$ & 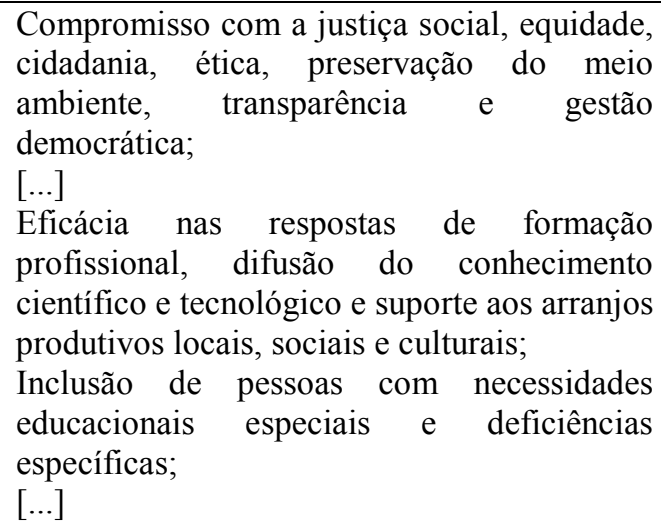 \\
\hline Finalidades e características: & $\begin{array}{r}\text { III. } \\
\text { IV. } \\
\\
\\
\text { V. } \\
\text { VI. } \\
\text { VII. } \\
\text { VIII. } \\
\\
\text { IX. }\end{array}$ & 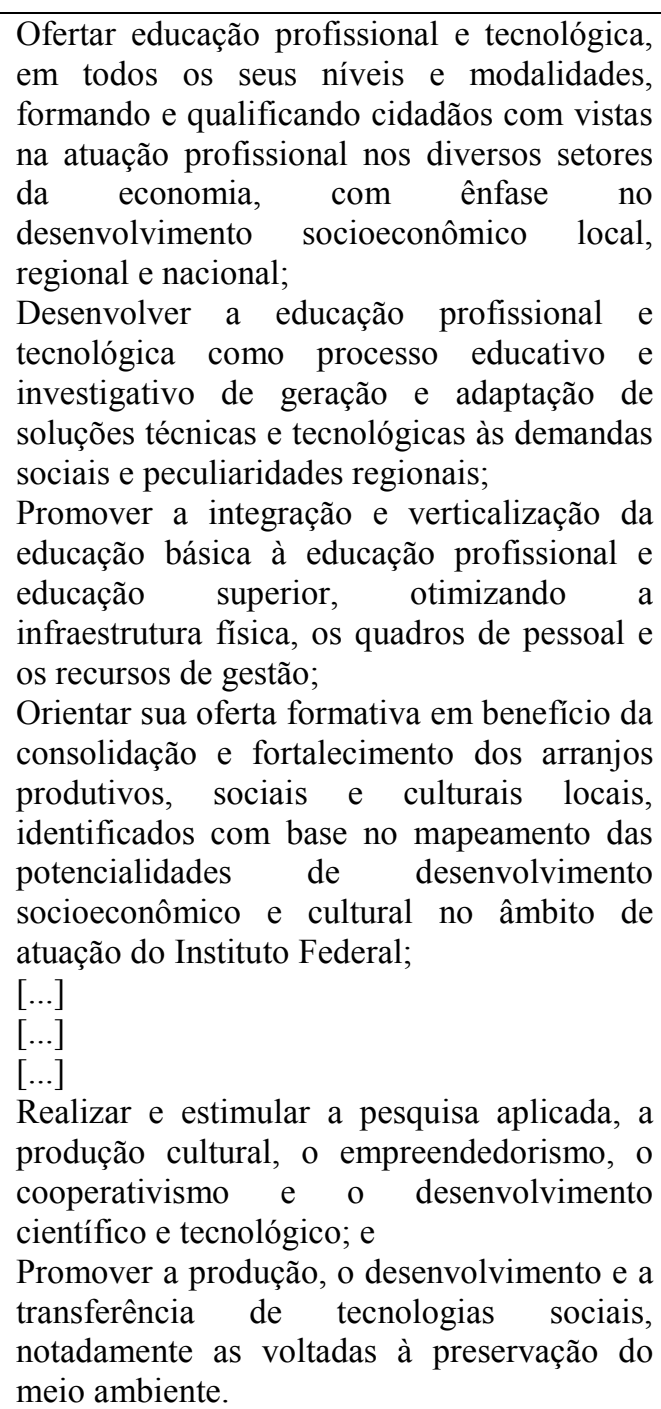 \\
\hline
\end{tabular}

Continua... 


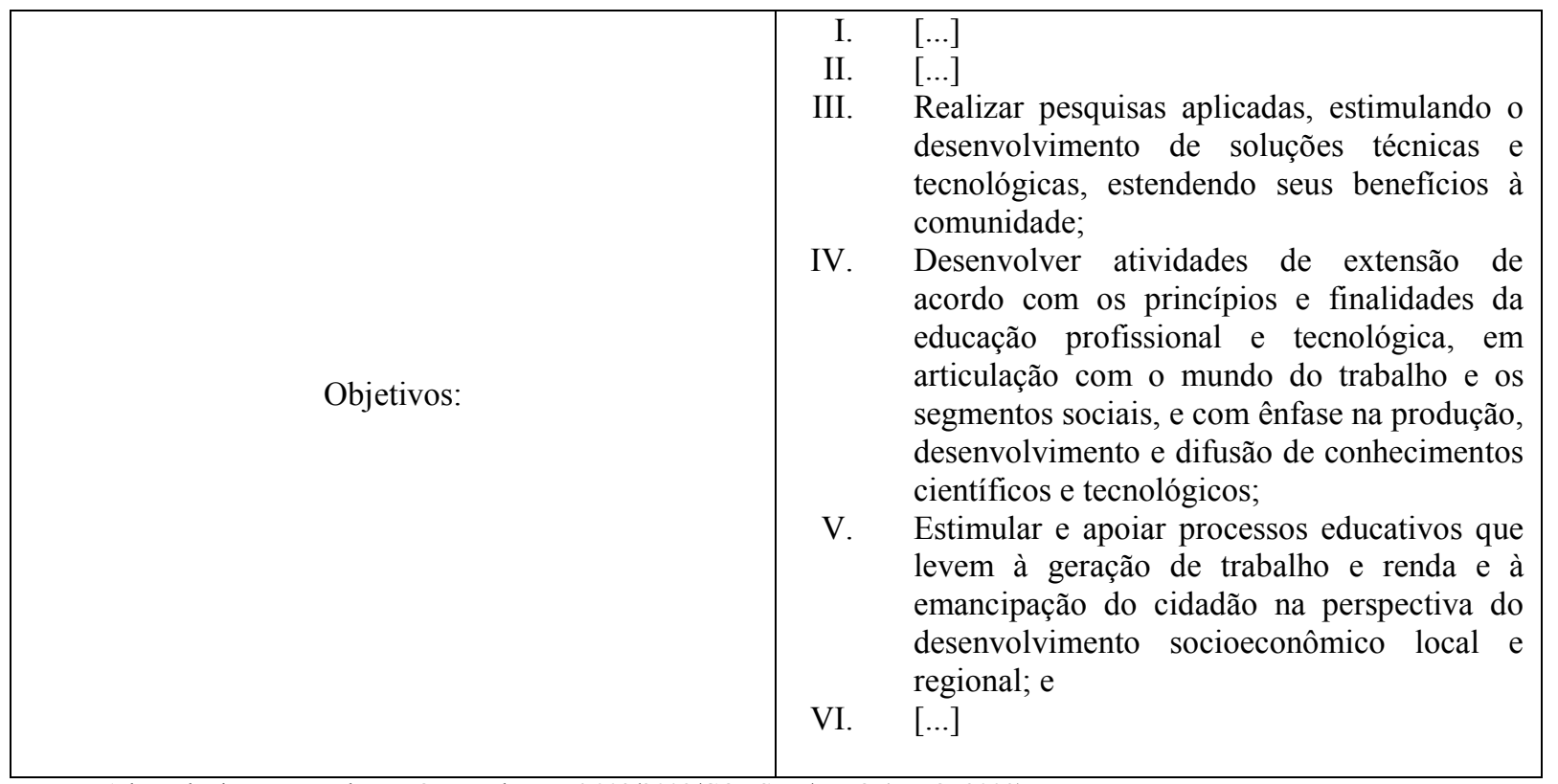

Fonte: Adaptado do Estatuto do IFRO, Resolução nº 003/2009/CONSUP/IFRO (IFRO, 2009).

O Regimento Geral é o conjunto de normas que disciplinam as atividades comuns aos campi, Reitoria e aos vários órgãos e serviços integrantes da estrutura organizacional do IFRO, nos planos administrativos, didático-pedagógico e disciplinar, com o objetivo de complementar e normatizar as disposições estatutárias. (IFRO, 2011b).

Na busca pela presença de termos relacionados à sustentabilidade, não diferenciando suas dimensões, foram encontrados no Regimento Geral, no contexto relacionado às atribuições das Pró-Reitorias, além de outras competências, a atribuição de zelar pela integração das ações de extensão às necessidades acadêmicas, e pelo cumprimento dos objetivos, programas e regulamentos institucionais, tendo em vista a inclusão social; viabilizar mecanismos de acesso e permanência da sociedade às atividades desenvolvidas pelo IFRO, especialmente dos grupos menos favorecidos, pela oferta de projetos de formação; supervisionar os Núcleos de Atendimento às Pessoas com Necessidades Educacionais Específicas (NAPNE), nos campi quanto à implementação das políticas de inclusão traçadas pelo MEC e o IFRO (IFRO, 2011b). 
O que compete à Pró-Reitoria de Pesquisa, Inovação e Pós-Graduação ao que tange à manutenção da sustentabilidade foi zelar pela aplicação de ações de desenvolvimento do ensino na pós-graduação e da pesquisa e inovação tecnológica em todos os níveis de formação, bem como pelo cumprimento dos objetivos, programas e regulamentos institucionais, tendo em vista a sustentabilidade ambiental e a inclusão social;

Todas as Pró-Reitorias têm a atribuição de elaborar, com a equipe do setor, o Plano de Ação Anual, de acordo com as diretrizes contidas no PDI. Na seção que trata das disponibilidades e dos Objetivos da Instituição, o IFRO deverá:

i. Ofertar educação profissional e tecnológica, em todos os seus níveis e modalidades, formando e qualificando cidadãos com vistas na atuação profissional nos diversos setores da economia, com ênfase no desenvolvimento socioeconômico local, regional e nacional;

ii. Orientar sua oferta formativa em benefício da consolidação e fortalecimento dos arranjos produtivos, sociais e culturais locais, identificados com base no mapeamento das potencialidades de desenvolvimento socioeconômico e cultural no âmbito de atuação do Instituto Federal;

iii. Desenvolver a educação profissional e tecnológica como processo educativo e investigativo de geração e adaptação de soluções técnicas e tecnológicas às demandas sociais e peculiaridades regionais;

iv. Promover a integração e a verticalização da educação básica à educação profissional e educação superior, otimizando a infraestrutura física, os quadros de pessoal e os recursos de gestão; orientar sua oferta formativa em benefício da consolidação e fortalecimento dos arranjos produtivos, sociais e culturais locais, identificados com base no mapeamento das potencialidades de desenvolvimento socioeconômico e cultural no âmbito de atuação do Instituto Federal;

v. Realizar e estimular a pesquisa aplicada, a produção cultural, o empreendedorismo, o cooperativismo e o desenvolvimento científico e tecnológico;

vi. Promover a produção, o desenvolvimento e a transferência de tecnologias sociais, notadamente as voltadas à preservação do meio ambiente. (IFRO, 2011b).

E por objetivos, conforme artigo $5^{\mathrm{o}}$ :

i. Ministrar cursos de formação inicial e continuada de trabalhadores, objetivando a capacitação, o aperfeiçoamento, a especialização e a atualização de profissionais, em todos os níveis de escolaridade, nas áreas da educação profissional e tecnológica;

ii. Realizar pesquisas aplicadas, estimulando o desenvolvimento de soluções técnicas e tecnológicas, estendendo seus benefícios à comunidade;

iii. Desenvolver atividades de extensão de acordo com os princípios e finalidades da educação profissional e tecnológica, em articulação com o mundo do trabalho e os segmentos sociais, e com ênfase na produção, desenvolvimento e difusão de conhecimentos científicos e tecnológicos;

iv. Estimular e apoiar processos educativos que levem à geração de trabalho e renda e à emancipação do cidadão na perspectiva do desenvolvimento socioeconômico local e regional (IFRO, 2011b). 
Também foram constatadas, no primeiro PDI do IFRO (exercício de 2009 a 2013), as dimensões da sustentabilidade como a preocupação em disponibilizar meios que fomentassem a sustentabilidade social. Esse documento tem a função de nortear e contribuir para a melhoria qualitativa e quantitativa das áreas estratégicas da instituição, com foco principal no cumprimento da missão institucional (IFRO, 2009).

No atual PDI, IFRO (2014), para o exercício de 2014 a 2018, dentre os objetivos e metas propostos pela Reitoria, ligadas à área de gestão ambiental, estão: adequar a infraestrutura dos campi aos parâmetros de sustentabilidade ambiental com vistas à diminuição dos custos de energia elétrica. Há previsão de cursos em EaD: especialização em Educação Ambiental com Ênfase em Espaços Educadores Sustentáveis e curso de extensão (curta duração), Educação Ambiental: Escolas Sustentáveis e Com-Vida. E na PósGraduação, Stricto Sensu (Mestrado), a proposta nesta área é para o curso de Desenvolvimento Sustentável, em parceria com CDS/UnB.

No final do exercício de 2015 foram aprovados pelas Resoluções $\mathrm{n}^{\mathrm{o}}$ 61/CONSUP/IFRO e nº 65/CONSUP/IFRO, o novo Estatuto e Regimento Geral do IFRO, respectivamente, pelo Conselho Superior (CONSUP), órgão consultivo e deliberativo da Instituição. Os novos documentos entraram em vigor a partir de primeiro de janeiro de 2016.

Fez-se necessária a análise nessa documentação em função que os documentos recém aprovados se comparados aos anteriores, estão com caráter mais propenso e direcionados ao cumprimento de ações que levem ao desenvolvimento nacional sustentável. No Regimento Geral (IFRO, 2015), foram inseridas competências aos servidores dos setores correlatos como:

À Coordenação do Núcleo de Inovação Tecnológica: organizar e promover cursos e capacitações referentes à Ciência e Tecnologia, Inovação, Empreendedorismo, Propriedade Intelectual, Desenvolvimento Sustentável; 
À Coordenação de Inclusão Social: fomentar a educação no campo, agricultura familiar, bem como outras ações para o desenvolvimento sustentável dos produtores rurais;

À Coordenação de Contratos e Convênios, bem como à Coordenação de Compras e Licitação: acompanhar a evolução legislativa e jurisprudência do TCU nos assuntos relacionados a contratos e convênios e compras e licitação, quanto às compras sustentáveis, a fim de adequarem os instrumentos contratuais e de compras à realidade da legislação e do IFRO.

À Direção de Planejamento: estabelecer diretrizes e gerenciar a elaboração de planejamento estratégico, tático e operacional, visando o desenvolvimento regional e propor ações de sustentabilidade com base no tripé da sustentabilidade, respeitando a legislação vigente aplicável às normas de ética ambiental e às diretrizes da política ambiental;

Diante do exposto, quanto à cultura organizacional da Instituição, foi percebido que há registro nos documentos organizacionais envolvendo a sustentabilidade, porém de acordo com dados levantados pelos servidores nas respostas dos questionários, a cultura da sustentabilidade está sendo construída, não havendo, contudo, algo institucionalizado entre toda a comunidade, visto que não é percebida pelo grupo. 


\section{CONSIDERAÇÕES FINAIS}

Com base nos dados obtidos, pôde-se afirmar que a evolução das compras públicas sustentáveis do IFRO não tem acompanhado a mesma efetividade se comparada ao Ministério em que está inserido, o MEC. Inclusive havendo decréscimo no decorrer do período de 2010 a 2015.

O perfil dos respondentes se caracterizou como servidores na condição de estáveis, no cargo de técnico administrativo de nível médio, com idade média de 34 anos, do sexo masculino, com titulação mínima de nível superior, na área de gestão pública e administração, com nenhuma experiência em compras públicas anterior ao IFRO e com elevada afinidade com o serviço em que está lotado.

Os principais fatores atrelados às dificuldades na implementação e execução das compras sustentáveis no IFRO, de acordo com os verificados na literatura e comparados com os da Instituição, foram os relacionados aos:

a) Informativos, exemplificados pela falta de familiaridade dos servidores com as CPS; falta de conscientização ambiental dos envolvidos; falta de preparo dos servidores e pela falta de percepção dentre as variáveis que representaram os fatores atrelados à catalogação de itens; disponibilidade de fornecedores; compra mais vantajosa; competitividade entre os fornecedores.

b) Organizacionais, como a falta de engajamento dos indivíduos e de definição de metas e ações por meio uma política devidamente institucionalizada, exemplificada pela falta de orientação para inserção de critérios sustentáveis; práticas isoladas que fomentam a sustentabilidade; falta de entendimento pelos pares da cultura da sustentabilidade organizacional. 
Embora uma das maiores dificuldade apontadas pelos servidores do IFRO tenha sido relacionada ao fator custo, subentende-se que seja em razão apenas por não haver um consenso sobre a compra mais vantajosa dentre os respondentes. Pois foi identificado que há uma predisposição ao apoio à aquisição e contratação de bens e serviços com característica sustentável, ainda que apresentem valores superiores aos tradicionais.

A percepção dos servidores envolvidos no processo de compras do IFRO, quanto à sustentabilidade, às compras sustentáveis e as dificuldades de implementação foi que, embora disponham de conhecimentos ao que tange à sustentabilidade, não se consideram familiar ás CPS.

Os respondentes indicaram incerteza nas respostas, quanto à clareza e aplicabilidade das legislações inerentes às CPS; quanto ao sistema de catalogação de produtos sustentáveis ser um facilitador na tomada de decisão para a aquisição de bens sustentáveis; se a alta gestão apoia as CPS. Entendem que, para efetividade das CPS o comportamento ambiental dos envolvidos deve ser favorável; que a dificuldade essencial a ser considerada na implementação das CPS é a resistência à mudança e que, a conscientização ambiental é fator primordial na contribuição das CPS.

O fator atrelado à resistência à mudança não pôde ser considerado um principal entrave, considerando o momento vivido pela Instituição e o pouco tempo de existência. A própria Instituição está em transição e adaptação, sendo passível de mudanças.

Quanto aos fatores que cooperam para a promoção do desenvolvimento sustentável, a percepção dos servidores é que a compra compartilhada foi considerada uma ferramenta eficaz, assim como o favorecimento às MPEs e as certificações ambientais. Porém há uma incerteza quanto ao entendimento se o princípio da competitividade está em consonância com a inserção de critérios sustentáveis nas contratações e que a proposta mais vantajosa inclui a promoção do desenvolvimento sustentável. 
Na rotina envolvida no processo de compras do IFRO, foi identificado que as compras compartilhadas é uma prática consolidada e que geralmente suprem às necessidades da Instituição. Já os fatores que mais cooperam para o atraso nas licitações são as falhas nas descrições de produtos e materiais, ausência de fornecedor interessado, atraso nas pesquisas de preço e justamente as compras compartilhadas.

$\mathrm{Na}$ Instituição, praticamente não há orientação além das indicadas nos pareceres da Procuradoria Jurídica, sobre a inserção de critérios sustentáveis nas descrições das solicitações, portanto, não sendo frequentes também, aquisições e contratações com essas características.

Possivelmente, a falta de orientação para a inserção de critérios sustentáveis possa estar relacionada à incerteza sobre o entendimento da compra mais vantajosa com a inclusão de critérios sustentáveis ou, ainda, pela dúvida quanto ao amparo das CPS no princípio da competitividade entre os fornecedores. Essa realidade causa uma insegurança nos gestores, quanto ao cumprimento da legislação e isso dificulta o comprometimento dos demais envolvidos

A percepção tanto dos servidores da Reitoria, quanto dos campi, sobre as práticas rotineiras da Instituição nos processos de compras, são semelhantes, indicando que há padronização nas ações voltadas para as compras, inclusive às relacionadas às compras sustentáveis.

Os setores envolvidos nos processos de compras do IFRO dispõem de uma integração moderada e há uma fiscalização efetiva para o recebimento dos materiais, o que colabora para o desempenho do processo de compras, visto que o trabalho não se perde até sua efetivação. Nas contratações de obras e serviços, em geral é priorizado o emprego da mão de obra de origem local e regional, questão evidenciada pela informação junto aos processos de serviços terceirizados. 
Quanto ao favorecimento às MPEs, ficou demonstrado que grande parte dos valores despendidos, no período de 2011 a março de 2016, foram destinadas às MPEs, o que contribui para a geração de emprego, renda e desenvolvimento, principalmente local e regional.

Quanto aos critérios de sustentabilidade ambiental, sobre a aquisição de produtos/materiais com menor número de embalagens, uso de refil e materiais reciclados ou recicláveis, o IFRO ainda não adotou tais práticas em sua rotina de compras, ocorrendo de modo esporádico, sem ser dada a devida prioridade, conforme preceitua a legislação concernente à gestão de resíduos sólidos.

$\mathrm{Na}$ aquisição de gêneros alimentícios, raramente são solicitados produtos orgânicos ou advindos da agricultura orgânica, todavia foi encontrado um nicho para esta prática, já que há oferta de refeição nos refeitórios dos campi agrícolas, principalmente, e a Instituição dispõe de profissionais no quadro de servidores com competências necessárias para gerenciar o cardápio, de acordo com a oferta dos produtos.

A Instituição tem adquirido equipamentos que visem critérios de eficiência energética, menor consumo de água e maior durabilidade, o que pode ser considerado um fator inerente à economia. Em relação à aplicação de critérios sustentáveis nas contratações de serviços, além dos exigidos pela legislação, também foram encontrados critérios solicitando que os funcionários terceirizados tivessem treinamento quanto à economia de água e energia, utilizassem EPIs e, produtos biodegradáveis na limpeza.

Baseadas nas análises pode-se afirmar que, o processo de compras do IFRO está em fase de adaptação à realidade da Instituição, devido à recente criação do Instituto, há apenas sete anos. Nesse período de transformação, mudanças significativas ocorreram como, a junção e a concentração de atribuições e atividades que antes poderiam ser discricionárias e, que agora concentram e dependem do consenso entre as unidades, causando uma interdependência. Por outro lado, essa condição de Instituição recém criada e de adaptações 
pode favorecer a inserção e disseminação de uma cultura de sustentabilidade organizacional se for devidamente conscientizada e amplamente divulgada.

Em se tratando da cultura organizacional da Instituição, constam nos documentos de origem e aos relacionados à gestão, ações referentes à promoção do desenvolvimento sustentável, porém não foram percebidas pelos respondentes. Indicando que a cultura da sustentabilidade está sendo construída, não havendo, contudo, algo institucionalizado entre toda a comunidade. Visto que não foi alcançada pelo grupo.

No tocante às compras governamentais, aprender, treinar e colocar em prática, são etapas que acontecem quase sempre simultaneamente, resultando em atropelos e teste de certo e errado. Isso decorre de constantes alterações nas leis que envolvem as compras e, ainda, o ingresso e a transição de servidores.

Esse cenário induz adaptações que precisam ser revistas, estudadas e testadas, foi o que os dados levantados pelos questionários e pelas demais observações revelaram. Para a adoção de atitudes e práticas em prol da sustentabilidade nas compras, é necessária uma diretriz pré-definida com a participação de todos os campi que compõem o IFRO, isso sim contribui para um maior comprometimento.

Esta pesquisa revelou que apesar da sustentabilidade ser um tópico presente nos planos de desenvolvimento da Instituição, não existe de fato uma política institucional voltada para o desenvolvimento sustentável.

Esse aspecto foi lembrado pelos respondentes ao destacarem a baixa incidência das orientações para a inserção de critérios sustentáveis, a falta de incentivo para o desenvolvimento de tais políticas, demonstradas pelas variáveis que indicaram o que a Instituição tem feito e quais as ações atreladas ao fomento das CPS ou desenvolvimento sustentável. 
O maior desafio para a implementação da política pública de compras sustentáveis está mais propenso à gestão. O problema está muito mais relacionado à cultura individual que converge na coletiva e, neste caso na organizacional relativa à conscientização sobre os aspectos sustentáveis.

Conforme evidenciado na investigação das dificuldades na implementação das CPS no IFRO, a orientação quanto à inserção de critérios sustentáveis é efetuada pela procuradoria jurídica, mas não de forma mais incisiva, ou seja, demonstrada pelos gestores. Como não há uma diretiva específica, e cobrada pela alta gestão; acontece de forma isolada, discricionária e sem um comprometimento em favor da sustentabilidade, como é necessária pela legislação.

Por fim, tem-se claro que as mudanças nas compras públicas no IFRO precisam ocorrer na cultura e no desenvolvimento da execução do processo de compras. Precisa haver um anseio comum para querer mudar. E para isso é preciso que haja um consenso, um objetivo a ser construído dentro da cultura organizacional, com especificações de normas em conjunto com trabalho de divulgação para a internalização de princípios norteadores de uma prática que precisa ser desenvolvida.

Portanto de acordo com o exposto pode-se concluir que no IFRO o principal entrave é a incerteza de como proceder para implantar a política de desenvolvimento sustentável na Instituição. Isso se justifica, possivelmente pela falta de familiaridade com o tema, o que gera uma estagnação baseada na insegurança pelo desconhecimento.

Como limitação à pesquisa, teve-se a participação específica somente dos servidores ligados aos processos de compras da Instituição, cerceando a percepção a um grupo seletivo. Como sugestão, fica a proposta de novo estudo abrangendo todos os servidores, com a utilização de questionário eletrônico destinado a esse público, com questões menos técnicas, a fim de ampliar a participação, haja vista que todos os servidores, são potenciais solicitantes de insumos e serviços. 
Dessa forma poderá analisar a necessidade e os gaps de cada setor sobre a inserção de critérios sustentáveis nas solicitações, bem como promover ampla divulgação ao tema, inclusive recebendo sugestões para catalogação de bens e serviços com características sustentáveis, de acordo com as especificidades dos setores.

\section{SUGESTÕES:}

Como contribuições deste estudo de caso apresentam-se sugestões ao IFRO baseadas nas análises das dificuldades elencadas na literatura e comparadas às da Instituição:

i. Capacitar servidores para atuar como multiplicadores na comunidade interna e externa do IFRO, sobre assuntos inerentes à sustentabilidade e emprego das CPS como ferramenta de contribuição para a Política Nacional de Desenvolvimento Sustentável;

ii. Criar um comitê central de CPS e sustentabilidade, estabelecido na Reitoria e nos campi, com participação dos seguimentos do corpo docente, discentes, técnicos da área de agrárias, gestão pública, nutrição, ambiental, contador, compras e licitação, almoxarifado e patrimônio e os diretores de planejamento e administração.

iii. Criar e institucionalizar a política de desenvolvimento nacional sustentável com a utilização das CPS, com apoio da alta gestão e diretoria de comunicação, para fins de ampla divulgação por meio de cartilhas informativas e participação da comunidade do IFRO;

iv. Efetuar estudo com a participação dos demandantes de materiais e serviços do IFRO, a fim de catalogar produtos e serviços passíveis de inclusão de critérios sustentáveis para alimentar o CATMAT, com as devidas especificações técnicas; 


\section{REFERÊNCIAS}

ALMEIDA, Alexandre Nascimento de. Comparação entre a competitividade do Brasil e Canadá para produção de madeira serrada. 2010. 209 f. Tese (Doutorado em Ciências Florestais) - Setor de Ciências Agrárias, Universidade Federal do Paraná, Curitiba, 2010.

ALENCASTRO, Maria Alice Cruz; SILVA, Edson Vicente da; LOPES, Ana Maria D’Ávila. Contratações sustentáveis na administração pública brasileira: a experiência do poder executivo federal. Revista de Administração Pública, Rio de Janeiro, v. 48, n. 1, p.207-235, jan./fev. 2014.

ARAGÃO, José Lima de; PFEIFER, Luiz Francisco Machado; BOMERO, Manuel Antônio Valdés. Ocupação tardia e o desenvolvimento da agropecuária no estado de Rondônia: uma história da bovinocultura no desenvolvimento regional. Revista Semina, Passo Fundo, v.13, n.1, p.154-171, nov. 2014.

BARDIN, Laurence. Análise de conteúdo. 70. ed. São Paulo: Edições, 2011.

BARKI, Teresa Villac Pinheiro; GONÇALVES-DIAS, Sylmara Lopes Francelino. Licitações sustentáveis no Brasil: Aspectos jurídicos e de gestão pública. In Congresso CONSAD de Gestão Pública, VII, 2014, Centro de Convenções Ulysses Guimarães, Brasília/DF: 25, 26 e 27 de março. 28p.

BATISTA, Marco Antonio Cavalcanti; MALDONADO, José Manuel Santos de Varge. O papel do comprador no processo de compras em instituições públicas de ciência e tecnologia em saúde. Revista de Administração Pública, Rio de Janeiro, v.42, n.4, p.681-699, jul./ago. 2008 .

BETIOL, Luciana Stocco et al. Compra sustentável: A força do consumo público e empresarial para uma economia verde e inclusiva. São Paulo: FGV, 2012.

BILHIM, João Abreu de Faria. Questões actuais de gestão de recursos humanos. Lisboa: Instituto Superior de Ciências Sociais e Políticas. 2002.

O papel dos gestores na mudança cultural da administração central do Estado: o caso da meritocracia. Passagens Revista Internacional de História Política e Cultura Jurídica, Rio de Janeiro, vol. 5, n.2, p.205-227, maio/ago. 2013. 
BITTENCOURT, Sidney. Licitações Sustentáveis: o uso do poder de compra do Estado fomentando o desenvolvimento nacional sustentável. Belo Horizonte: Del Rey, 2014.

BRAMMER, Stephen; WALKER, Helen. Sustainable procurement in the public sector: an international comparative study. International Journal of Operations \& Production Management, v. 31, n. 4, p.452-476, 2011.

BRASIL, Constituição da República Federativa do Brasil, Brasília, DF: Senado, 1988.

. Lei $\mathrm{n}^{\circ}$ 9.854, de 27 de outubro de 1999. Altera dispositivos da Lei n 8.666/93, de 21 de junho de 1993, que regula o art. 37, inciso XXI, da Constituição Federal, institui normas para licitações e contratos da Administração Pública e dá outras providências. Brasília/DF. Disponível em: http://www.planalto.gov.br/ccivil_03/Leis/L9854.htm. Acesso em 17 jan. 2016.

Lei Complementar $\mathrm{n}^{\circ} 123$, de 14 de Dezembro de 2006. Institui o Estatuto Nacional da Microempresa e da Empresa de Pequeno Porte, altera dispositivos das Leis $n^{\circ} 8$. 212 e n8.213, ambas de 24 de julho de 1991, da Consolidação das Leis do Trabalho - CLT, aprovada pelo Decreto-Lei $\mathrm{n}^{\circ} 5.452$, de $1^{\circ}$ de maio de 1943, da Lei $\mathrm{n}^{\circ} 10.189$, de 14 de fevereiro de 2001, da Lei Complementar $\mathrm{n}^{\circ} 63$, de 11 de janeiro de 1990, e revoga as Leis $\mathrm{n}^{\circ}$ 9.317, de 5 de dezembro de 1996, e 9.841, de 5 de outubro de 1999. Brasília/DF. Disponível em: http://www.planalto.gov.br/ccivil_03/Leis/LCP/Lcp123.htm. Acesso em: 12 jun. 2014.

Lei n ${ }^{\circ} 11.892$ de 29 de dezembro de 2008. Institui a Rede Federal de Educação Profissional, Científica e Tecnológica, cria os Institutos Federais de Educação, Ciência e Tecnologia, e dá outras providências. Brasília/DF. Disponível em:

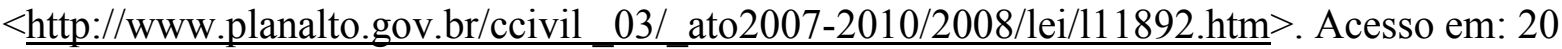
set. 2015.

. Lei $\mathrm{n}^{\circ} .11 .947$, de 16 de junho de 2009. Dispõe sobre o atendimento da alimentação escolar e do Programa Dinheiro Direto na Escola aos alunos da educação básica; altera as Leis $\mathrm{n}^{\circ} 10.880$, de 9 de junho de 2004, $\mathrm{n}^{\circ} 11.273$, de 6 de fevereiro de 2006, $\mathrm{n}^{\circ} 11.507$, de 20 de julho de 2007; revoga dispositivos da Medida Provisória n 2.178-36, de 24 de agosto de 2001, e a Lei $\mathrm{n}^{\circ}$ 8.913, de 12 de julho de 1994; e dá outras providências. Brasília/DF. Diário Oficial da União. 17 set 2009.

Ministério do Planejamento, Orçamento e Gestão. Secretaria de Logística e Tecnologia da Informação - SLTI. Guia para Implementação de Compras Públicas Sustentáveis na Administração Federal. Brasília: MP, 2010. 76p. 
Instrução Normativa $\mathrm{n}^{\mathrm{o}}$. 10, de 12 de novembro de 2012a. Disponível em:

$<$ http://www.ambiente.sp.gov.br/wp-content/uploads/2015/02/IN-MPOG-10-12-112012>.pdf>. Acesso em: 14 nov. 2015.

Decreto $n^{\circ} 7.746$, de 05 de junho de 2012b. Regulamenta o art. $3^{\circ}$ da Lei $n^{\circ}-8.666$, de 21 de junho de 1993, para estabelecer critérios, práticas e diretrizes para a promoção do desenvolvimento nacional sustentável nas contratações realizadas pela administração pública federal, e institui a Comissão Interministerial de Sustentabilidade na Administração Pública CISAP. Brasília/DF. Disponível em: < http://www.planalto.gov.br/CCIVIL_03/_Ato20112014/2012/Decreto/D7746.htm>. Acesso em: 14 nov. 2015.

. Decreto $\mathrm{n}^{\mathrm{o}} 7.775$, de 04 de julho de 2012c. Regulamenta o art. 19 da Lei $\mathrm{n}^{\mathrm{o}} 10.696$, de 2 de julho de 2003, que institui o Programa de Aquisição de Alimentos, e o Capítulo III da Lei $\mathrm{n}^{\mathrm{o}}$ 12.512, de 14 de outubro de 2011, e dá outras providências. Disponível em: $<$ http://www.planalto.gov.br/ccivil 03/ ato2011-2014/2012/decreto/d7775.htm\#art17v. $>$. Acesso em: 30 out. 2015.

Ministério do Planejamento, Orçamento e Gestão. Caderno de Logística n. 4: Comprando das micro e pequenas empresas. 2013a. Disponível em: $<$ http://www.comprasgovernamentais.gov.br/arquivos/sustentabilidade/comprando-dasmicro-e-pequenas-empresas-revisado.pdf/view >. Acesso em: 22 set. 2015

. Decreto $\mathrm{n}^{\mathrm{o}} 7.892$, de 23 de janeiro de 2013b. Regulamenta o Sistema de Registro de Preços previsto no art. 15 da Lei no 8.666, de 21 de junho de 1993. Brasília/DF. Disponível em: http://www.planalto.gov.br/CCIVIL_03/_Ato2011-2014/2013/Decreto/D7892.htm. Acesso em: 14 nov. 2015.

Ministério do Planejamento, Orçamento e Gestão. Secretaria de Logística e Tecnologia da Informação SLTI. Planos de gestão de logística sustentável: contratações públicas sustentáveis. Caderno de estudo e pesquisa 1: Política pública e sustentabilidade. Brasília: SLTI, 2014a. 30p.

Lei Complementar $n^{\circ} 147$, de 07 de agosto de 2014b. Altera a Lei Complementar $\mathrm{n}^{\mathrm{o}}$ 123, de 14 de dezembro de 2006, e as Leis $\mathrm{n}^{\text {os }} 5.889$, de 8 de junho de $1973,11.101$, de 9 de fevereiro de 2005, 9.099, de 26 de setembro de 1995, 11.598, de 3 de dezembro de 2007, 8.934, de 18 de novembro de 1994, 10.406, de 10 de janeiro de 2002, e 8.666, de 21 de junho de 1993; e dá outras providências. Brasília/DF. Disponível em:

http://www.planalto.gov.br/CCIVIL_03/LEIS/LCP/Lcp147.htm. Acesso em: 05 jan. 2016 
. Decreto n ${ }^{\circ} 8.473$, de 22 de junho de 2015. Estabelece, no âmbito da Administração Pública federal, o percentual mínimo destinado à aquisição de gêneros alimentícios de agricultores familiares e suas organizações, empreendedores familiares rurais e demais beneficiários da Lei ${ }^{\circ} 11.326$, de 24 de julho de 2006, e dá outras providências. Brasília/DF. Disponível em: $<$ http://www.planalto.gov.br/ccivil_03/ ato20152018/2015/decreto/d8473.htm>. Acesso em: 30 out. 2015.

BRESSAN, Flávio. O método do estudo de caso. Administração On Line FECAP, v. 1, número 1, janeiro-março 2000.

BRYNER, Gary C. Organizações públicas e políticas públicas. In: PETERS, B. Guy; PIERRE, Jon. (Org). Administração pública: coletânea. Tradução YAMAMOTO, Sonia Midori; OLIVEIRA, Miriam.Brasília: UNESP/ENAP, 2010. p.315-333.

BÚRIGO, Carla Cristina Dutra; MARTINS, Walquiria. A gestão de compras: uma relação com a expansão da rede federal de educação profissional e tecnológica. In: XV COLÓQUIO INTERNACIONAL DE GESTÃO UNIVERSITÁRIA - CIGU, Desafios da Gestão Universitária no XXI, 2015, Mar del Plata.

CAPELLA, Ana Cláudia N. Perspectivas Teóricas sobre o processo de formulação de políticas públicas. In HOCHMAN, Gilberto; ARRETCHE, Marta; MARQUES, Eduardo. Políticas Públicas no Brasil. Rio de Janeiro, Fiocruz, 2007, p.87-122.

CASTRO, Joana D'arc Bardella et al. Hábitos de consumo sustentável: uma realidade para a cidade de Anápolis - GO. Gestão, Inovação e Negócios, v. 1, n.1, p.01-18, 2015.

CIMA. Presidência da República. Comissão Interministerial para a Preparação da Conferência das Nações Unidas sobre Meio Ambiente e Desenvolvimento. O desafio do desenvolvimento sustentável; pref. Do presidente Fernando Collor. - Brasília: Cima, 1991.

COGO, Giselle Alves da Rocha. Critérios de sustentabilidade nas aquisições de bens e contratações de serviços da gestão pública federal. 2015. 113 f. Dissertação (Mestrado em Engenharia de Produção) - Universidade Tecnológica Federal do Paraná, Ponta Grossa, 2015.

COSTA, Carlos Eduardo Lustosa. As licitações sustentáveis na ótica do controle externo. Interesse Público - IP, Belo Horizonte, ano 14, n. 71, p.243-278, jan./fev. 2012.

COSTIN, Claudia. Administração Pública. Rio de Janeiro: Elsevier, 2010. 
COUTO, Hugo Leonardo Gomides do; COELHO, Cristiano. Fatores críticos no comportamento do gestor público responsável por compras sustentáveis: diferenças entre consumo individual e organizacional. Revista de Administração Pública, Rio de Janeiro, v. 49, n.1, p.519-543, mar./abr. 2015.

CRESWELL, John W. Projeto de pesquisa: métodos qualitativo, quantitativo e misto. Tradução LOPES, Magda França. 3.ed. Porto Alegre: Artmed, 2010.

CURY, Antonio. Organização e Métodos: uma visão holística. 8.ed. São Paulo: Atlas, 2006.

EGEBERG, Morten. Implicações da estrutura burocrática: uma perspectiva organizacional. In: PETERS, B. Guy; PIERRE, Jon. (Org). Administração pública: coletânea. Tradução YAMAMOTO, Sonia Midori; OLIVEIRA, Miriam. Brasília: UNESP/ENAP, 2010. p.147165.

FAO. Organização das Nações Unidas para a Alimentação e Agricultura. Compras públicas da agricultura familiar na América Latina e Caribe: uma política inovadora para erradicar a fome, 2015. Disponível em: <http://www.fao.org/in-action/programa-brasilfao/noticias/ver/pt/c/335409/>. Acesso em 14 out. 2015.

FARAH, Marta Ferreira Santos. Temas emergentes em gestão e políticas públicas: tendências gerais. Cadernos Gestão Pública e Cidadania, n. 48, p.43-66, 2006.

FOGLIATTI, Maria Cristina et al. Sistema de gestão ambiental para empresas. Rio de Janeiro: Interciência, 2008.

FERREIRA, Vítor Hugo Cortez Carvalho. Estudo da adoção de tecnologias pelas micro e pequenas empresas de retalho alimentar. 2015. 95f. Dissertação (Mestrado em Economia Industrial) - Universidade do Minho, Escola de Economia e Gestão, Portugal, 2015.

FIGUEIREDO, Gabriela Negrão de; ABREU, Regilane Lacerda; CASAS, Alexandre Luzzi Las Casas. Reflexos do índice de sustentabilidade empresarial (ISE) na imagem das empresas: uma análise do consumidor consciente e do marketing ambiental. Pensam. Real. 128, Ano XII - v. 24, n. 1/2009.

GARCIA, Flávio Amaral; Ribeiro, Leonardo Coelho. Licitações públicas sustentáveis. Revista de Direito Administrativo - RDA, Rio de Janeiro, v. 260, p.231-254, maio/ago. 2012. 
GAZZONI, Fernando et al. O papel das IES no desenvolvimento Sustentável: estudo de caso da Universidade Federal de Santa Maria. In: Fórum Internacional ECOINOVAR, 4, 2015, Santa Maria. p.1-14.

GONÇALVES, José Ernesto Lima. As empresas são grandes coleções de processos. RAE Revista de Administração de Empresas, São Paulo, v. 40, n.1, p.6-19, jan./mar. 2000.

GUNTHER, Hartmut. Pesquisa qualitativa versus pesquisa quantitativa: esta é a questão? Psicologia: Teoria e Pesquisa, Brasília, v. 22, n.2, p.201-210, maio/ago., 2006.

HAIR Jr. J. F.; ANDERSON, R.E.; TATHAM, R.L.; BLACK, W. C. Análise multivariada de dados. 5. ed., Porto Alegre: Bookman, 2005.

IBGE, Instituto Brasileiro de Geografia e Estatística, Microdados da Pesquisa Nacional por Amostra de Domicílios (PNAD), 2015

IFRO. Consup. Conselho Superior. Resolução n⿳0 003, de $1^{\mathbf{0}}$ de setembro de 2009a. Dispõe sobre o Estatuto do Instituto Federal de Educação, Ciência e Tecnologia de Rondônia. Conselho Superior (CONSUP). Publicado no D.O.U n 167, em 01 set. 2009.

Institucional. Plano de Desenvolvimento Institucional, 2009b (PDI 2009-2013). Disponível em: http://www.ifro.edu.br/site/wp-content/uploads/2009/04/PDI-IFRO.pdf. Acesso em: 14 nov. 2015.

Consup. Conselho Superior. Resolução n 07, de 15 de abril de 2011a. Dispõe sobre a Política de Capacitação dos Servidores do Instituto Federal de Educação, Ciência e Tecnologia de Rondônia Conselho Superior (CONSUP). Disponível em: $<$ http://www.ifro.edu.br/consup/index.php?option $=$ com_docman\&task $=$ cat_view\&gid $=15 \&$ It emid=11\&limitstart=40. $>$. Acesso em: 06 abr. 2016.

Consup. Conselho Superior. Resolução nº 021, de 21 de junho de 2011b. Dispõe sobre o Regimento Geral do Instituto Federal de Educação, Ciência e Tecnologia de Rondônia. Conselho Superior (CONSUP). Disponível em:

http://www.ifro.edu.br/consup/index.php?option $=$ com_docman\&task=cat_view\&gid=15\&Ite $\underline{\text { mid }=11 \& \text { limitstart }=25}$. Acesso em: 15 fev. 2016

PRODIN. Pró-Reitoria de Desenvolvimento Institucional. Plano de Desenvolvimento Institucional. Porto Velho, 2014. (PDI 2014-2018). Disponível em: http://estrategia.ifro.edu.br/pdi/wp-content/uploads/sites/6/2015/03/pdi-ifro-2014-2018versao-final-corrigida.pdf. Acesso em: 14 nov. 2015. 
. Institucional. Regimento Geral do IFRO. Porto Velho, 2015. Disponível em:

$<$ http://www.ifro.edu.br/site/wp-content/uploads/2009/04/Regimento-Geral-do-IFRO-Res.n\%C2\%BA-65-Consup-ifro.pdf. $>$. Acesso em: 15 fev. 2016.

IPEADATA. Renda - Desigualdade - coeficiente de Gini. Instituto de Pesquisa Econômica Aplicada. Brasil 2015. Disponível em: http://www.ipeadata.gov.br/>. Acesso em 06 abr. 2015.

JUSTEN FILHO, Marçal. Comentários a lei das licitações e contratos administrativos. 14.ed. São Paulo: Dialética, 2010.

LAVORATO, Marilena Lino de Almeida. Cultura de sustentabilidade para transformar realidades. In: BELLUCCI, Obata (Org). Ciência e tecnologia como vetores para a sustentabilidade. São Paulo: Vespa Comunicações, 2013. p.40-47.

MACIEL, Carlos Alberto Batista. Políticas Públicas e controle Social: encontros e desencontros da experiência brasileira. In: X Congresso Internacional de Humanidades. 2007.

MALHOTRA, Naresh K. Elaboração de Questionários e Formulários. In: Pesquisa de Marketing: uma orientação aplicada. São Paulo: Bookman, 2004. cap.10.

MARQUES, Antônio Luiz et al. Relações entre resistência e comprometimento organizacional em servidores públicos de Minas Gerais. RAC, Rio de Janeiro, v. 18, n.3, p.161-175, mar./abr. 2014.

MARTINELLI: Suellen Secchi et al. Potencialidades da compra institucional na promoção de sistemas agroalimentares locais e sustentáveis: o caso de um restaurante universitário. Segurança Alimentar e Nutricional, Campinas, v. 22, n.1, p.558-573. 2015.

MDS. Ministério do Desenvolvimento Social e Combate à Fome. Compra Institucional amplia oportunidades para agricultura familiar. Disponível em:> http://www.mds.gov.br/saladeimprensa/noticias/2015/janeiro/compra-institucional-ampliaoportunidades-paraagricultura-familiar>. Acesso em: 01 fev. 2016.

MEIRELLES, Hely Lopes. Direito Administrativo Brasileiro, atualizada em sua 18 ed. por Eurico de Andrade Azevedo, Délcio Balestero Aleixo e Jose Emmanuel Burle Filho. 2006.

MENDONÇA, Ricardo Almeida Marques et al. Processo de institucionalização das compras públicas sustentáveis. In: ENAPG, 2012, Salvador. Anais.... Salvador: Anpad, 2012. p.1-16. 
MEYERS, Marcia K.; VORSANGER, Susan. Burocratas de nível de rua e a implementação de políticas públicas. In: PETERS, B. Guy; PIERRE, Jon (Org.). Administração Pública: coletânea. Tradução YAMAMOTO, Sonia Midori; OLIVEIRA, Miriam. Brasília: UNESP/ENAP, 2010. p.249-270.

MOTTA, Helaine do Amaral. OLIVEIRA, Lilian Firme Pittou de. Compras e contratações públicas federais sustentáveis: desafios na participação de micro e pequenas empresas do Município de São Mateus/ES. Gestão Contemporânea, Vila Velha, v.5, n. 2, p. 62-80, out. 2015.

MPOG. Informações gerenciais de contratações públicas sustentáveis janeiro a dezembro de 2014. Brasília: MPOG, 2014. Disponível em:

$<$ http://www.comprasgovernamentais.gov.br/arquivos/estatisticas/03-apresentacao-siasgcompras-sustentaveis-_2014.pdf $>$. Acesso em: 25 mar. 2015.

Ministério do Planejamento, Orçamento e Gestão. Contratações Públicas

Sustentáveis. Brasília: MPOG, 2015: Disponível em:

http://cpsustentaveis.planejamento.gov.br/. Acesso em: 08 abr. 2015.

. Ministério do Planejamento, Orçamento e Gestão. Portal de compras do governo federal.Brasília: MPOG, 2016. Disponível em:

http://paineldecompras.planejamento.gov.br/QvAJAXZfc/opendoc.htm?document=Painel\%2 0de\%20Compras.qvw\&host=Local\&anonymous=true. Acesso em: 23 mar. 2016.

NONATO, Raquel Sobral. Compras públicas sustentáveis no Brasil: análise da produção e circulação das ideias a partir da ressignificação dos atores. 2015. 133 f. Dissertação (Mestrado em Administração Pública e Governo) - Escola de Administração de Empresas da Fundação Getúlio Vargas de São Paulo, São Paulo, 2015.

OLIVEIRA, Antonio. Burocratas da linha de frente: executores e fazedores das políticas públicas. Revista de Administração Pública, Rio de Janeiro, v. 46, n. 6, p.1551-1573, nov./dez. 2012.

OLIVEIRA, Bernardo Carlos S. C. M. de; SANTOS, Luis Miguel Luzio dos. Compras públicas como política para o desenvolvimento sustentável. Revista de Administração Pública, Rio de Janeiro, v. 49, n. 1, p.189-206, jan./fev. 2015.

PEGN, Revista Pequenas Empresas Grandes Negócios. SEBRAE lança buscador de licitações públicas para micro e pequenas empresas. Disponível em:

$<\underline{\text { http://revistapegn.globo.com/Empreender/noticia/2015/12/sebrae-lanca-buscador-de- }}$ licitacoes-publicas-para-micro-e-pequenas-empresas.html >. Acesso em: 19 jan. 2016. 
PESTANA, Maria Helena; GAGEIRO, João Nunes. Análise de dados para ciências sociais - a complementaridade do SPSS. 4. ed. Lisboa: Silabo, 2005.

PETERS, B. Guy; PIERRE, Jon. O papel da gestão pública no governo. In: (Org.). Administração Pública: coletânea. Tradução YAMAMOTO, Sonia Midori; OLIVEIRA, Miriam. Brasília: UNESP/ENAP, 2010. p.15-29.

PIRES, José Calixto de Souza; MACÊDO, Kátia Barbosa. Cultura organizacional em organizações públicas no Brasil. Revista de Administração Pública, Rio de Janeiro v. 40 n.1, p.81-105, jan./fev. 2006.

PRZYBYSZ, Leane Chamma Barbar; NAVROSKI, Eliane Pires; WAGNER, Adriana Franzoi. Políticas Públicas Ambientais. 1 ed. Curitiba: Instituto Federal do Paraná, (e-Tec Brasil), 2012.

RADIN, Beryl A. Os instrumentos da gestão intergovernamental. In: PETERS, B. Guy; PIERRE, Jon (Org.). Administração Pública: coletânea. Tradução YAMAMOTO, Sonia Midori; OLIVEIRA, Miriam. Brasília: UNESP/ENAP, 2010. p.597-618.

ROSINI, Alessandro Marco et al. Educação financeira, consumo e sustentabilidade ambiental. REPAE - Revista Ensino e Pesquisa em Administração e Engenharia, São Paulo, v. 1, n. 1, p.4-14, jan./jun. 2015.

ROSSETTI, Suzana Maria. As políticas públicas de fomento às micro e pequenas empresas: desenvolvimento social e perspectivas frente a uma administração pública inclusiva. Revista do Direito, Santa Cruz do Sul, v. 3, n.47, p.144-173, set./dez. 2015.

SANTIAGO, Leonardo Ayres. Aspectos das Licitações Sustentáveis. Disponível em: $<$ http://www.licitacoessustentaveis.com/2009/08/apresentacao.html $>$. Acesso em junho de 2011.

SANTOS, Murillo Giordan; BARKI, Teresa Villac Pinheiro. Licitações e contratações públicas sustentáveis. Belo Horizonte: Fórum, 2011.

SECCHI, Leonardo. Políticas públicas: conceitos, esquemas de análise, casos práticos. 2. ed. São Paulo: Cengage Learning, 2013. 
SEPOG Secretaria de Estado do Planejamento e Coordenação Geral de Rondônia. Produto Interno Bruto (PIB) de Rondônia. Porto Velho: GEP/SEPLAN/RO, 2012. 54p

SIAFI GERENCIAL. Sistema Integrado da Administração Financeira do Governo Federal. Disponível em: <http://acesso.serpro.gov.br/> Acesso em: 15 mar. 2016.

SILVA, Christian Luiz da; LIMA, José Edmilson de Souza. Políticas Públicas e Indicadores para o desenvolvimento sustentável. 1.ed. São Paulo: Saraiva, 2011.

SILVA, Renato Cader da; BARKI, Teresa Villac Pinheiro. Compras públicas compartilhadas: a prática das licitações sustentáveis. Revista do Serviço Público. Brasília, v 63, n. 2, p.157175, abr/jun. 2012.

SILVA, Renato Cader da. Compras compartilhadas sustentáveis. Disponível em: $<\underline{\text { http://www.comprasgovernamentais.gov.br/paginas/artigos/compras-compartilhadas- }}$ sustentaveis $>$. Acesso em: 22 set. 2015.

SOUZA, Celina. Estado da arte da pesquisa em políticas públicas. In HOCHMAN, Gilberto; ARRETCHE, Marta; MARQUES, Eduardo. Políticas Públicas no Brasil. Rio de Janeiro, Fiocruz, 2007, p.65-86.

SOUZA, Nali de Jesus. Desenvolvimento Econômico. 4. ed. São Paulo: Atlas, 1999.

SOUZA, Renato Santos de. Entendendo a questão ambiental: temas de economia, política e gestão do meio ambiente. Santa Cruz do Sul: EDUNISC, 2000.

TARAPANOFF, Kira. Referencial Teórico: introdução. In: organizacional e competitiva. Brasília: UnB, 2001. 344 p. . (Org.). Inteligência

TCU. Tribunal de Contas da União - TCU. Licitações e contratos: orientações e jurisprudência do TCU, 4.ed.rev., atual e ampl. Brasília: TCU, Secretaria-Geral da Presidência: Senado Federal, Secretaria Especial de Editoração e Publicações, 2010. 910p.

TEIXEIRA, Izabella Mônica Vieira. O uso da avaliação ambiental estratégica no planejamento da oferta de blocos para exploração e produção de petróleo e gás no Brasil: uma proposta. 2008. 308 f. Tese (Doutorado) - Coppe/Universidade Federal do Rio de Janeiro, Rio de Janeiro, 2008. 
TEIXEIRA, Maria Fernanda de Faria Barbosa. Desafios e oportunidades para a inserção do tripé da sustentabilidade nas contratações públicas: um estudo de caso do Governo Federal brasileiro e do governo do Estado de São Paulo. 2013. 312 f. Dissertação (Mestrado em Desenvolvimento Sustentável) - Universidade de Brasília, Brasília, 2013.

VEIGA, José Eli da. Desenvolvimento Sustentável: o desafio do século XXI. 3.ed. Rio de Janeiro: Garamond Universitária, 2008.

VERGARA, Sylvia Constant . Projetos e relatórios de pesquisa em administração, 14 ed. São Paulo. Atlas, 2013.

VIEGAS, Socorro de Fátima da Silva; CABRAL, Eugênia Rosa. Revista Gestão Universitária na América Latina - GUAL, Florianópolis, v. 8, n.1, p.236-259, jan. 2015.

WATANABE, Carmem Ballão. Conservação Ambiental. 1 ed. Curitiba: Instituto Federal do Paraná, (e-Tec Brasil) 2011.

UNESCO Organização das Nações Unidas para a Educação, a Ciência e a Cultura http://www.unesco.org/new/pt/brasilia/about-this-office/prizes-and-celebrations/2005-2014the-united-nations-decade-of-education-for-sustainable-development/acessado em maio de 2014.

WINTER, Soren C. Perspectivas de implementação: status e reconsideração. In: PETERS, B. Guy; PIERRE, Jon (Org.). Administração Pública: coletânea. Tradução YAMAMOTO, Sonia Midori; OLIVEIRA, Miriam. Brasília: UNESP/ENAP, 2010. p.209-228.

YIN, Robert K. Estudo de caso: planejamento e métodos. 4. Ed. Porto Alegre: Bookman, 2010.

ZANELLA, Liane Carly Hermes. Metodologia de Estudo e Pesquisa em Administração, Florianópolis: Departamento de Ciências da Administração / UFSC; [Brasília]: CAPES UAB, 2009. 


\title{
APÊNDICE A - CARTA DE APRESENTAÇÃO DA PESQUISA
}

\author{
Carta de Apresentação
}

Colorado do Oeste, Rondônia, Outubro de 2015

Eu Juliana Vieira Saldanha, mestranda do Programa de Pós-Graduação em Gestão Pública (PPGP), do Mestrado Profissional em Gestão Pública da Faculdade de Planaltina (FUP) da Universidade de Brasília (UnB) estou desenvolvendo a pesquisa intitulada Exequibilidade das Contratações Públicas Sustentáveis em uma Instituição de Ensino da Região Norte do Brasil.

A referida pesquisa é um estudo de caso no Instituto Federal de Rondônia e tem como objetivo identificar quais os fatores que dificultam a exequibilidade na implementação das compras sustentáveis no IFRO. O universo da pesquisa serão os servidores envolvidos nos processos de compras, identificando a rotina, a cultura organizacional e a percepção quanto à temática da sustentabilidade ambiental, especificamente quanto ás Contratações Públicas Sustentáveis.

Esta carta é dirigida aos servidores do IFRO e a quem possa interessar a fim de tornar público e formalizar minhas possíveis visitas aos Campi e Reitoria, e que para tanto peço a colaboração e compreensão para o desenvolvimento da pesquisa.

Juliana Vieira Saldanha

Aluna do PPGP 


\section{APÊNDICE B - QUESTIONÁRIO UTILIZADO NA PESQUISA}

\section{APRESENTACÃO E TERMO DE CONSENTIMENTO}

Este questionário aborda a temática das compras públicas sustentáveis e tem como propósito identificar as dificuldades no processo de implementação no Instituto Federal de Rondônia. A pesquisa é referente ao Programa de Pós-Graduação em Gestão Pública, mestrado profissional pela Faculdade de Planaltina (FUP), da Universidade de Brasília (UnB). Caso não queira identificar-se, fique à vontade. As informações obtidas não serão utilizadas de forma individualizada, uma vez que as respostas serão agregadas. O tempo para o preenchimento é de aproximadamente 20 minutos e, caso haja alguma questão que não tenha como responder, deixe-a em branco, por favor. Obrigada.

Nome:

Contato: Juliana Vieira Saldanha. Campus Colorado do Oeste. (juliana.saldanha@ifro.edu.br) CRITÉRIO DE INCLUSÃO

Este instrumento de pesquisa será aplicado exclusivamente aos servidores envolvidos aos processos de compras e contratações públicas do Instituto Federal de Rondônia, dos campi e da Reitoria.

\section{DIMENSÃO DEMOGRÁFICA E FUNCIONAL}

Idade:

Gênero: ( ) Masculino

( ) Feminino

Grau de instrução:

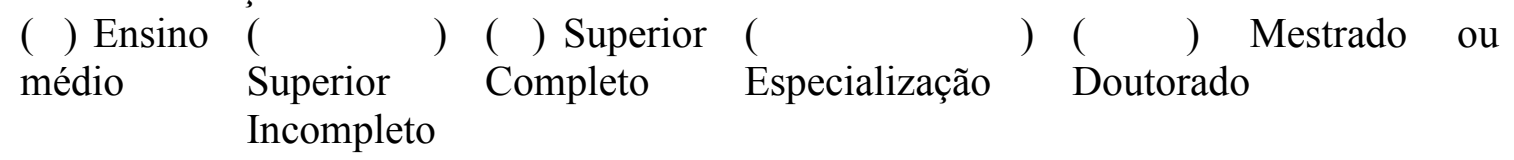

Formação:

Campus:

\section{$\overline{\text { Setor: }}$}

$\begin{array}{lllll}\text { ( ) Reitoria } & \text { ( ) PROPLAD } & \text { ( ) DPLAD } & \text { ( ) CCL } & \text { ( ) CPALM } \\ \text { ( ) CGCON } & \text { ( ) COFIN } & \text { ( ) Outro } & \end{array}$

Cargo/Função: （ ) TAE ～( ) Docente

Nome do cargo e função:

Número de servidores no setor:

Tempo de serviço público: (em meses)

Teve experiência em processo de compras públicas, em serviço anterior ao IFRO?
( ) nenhuma
( ) pouca
( ) moderada
( ) elevada
( ) muito
elevada

Tem afinidade com o serviço que desempenha no setor em que está lotado?
( ) nenhuma
( ) pouca
( ) moderada
( ) elevada
( ) muito
elevada 


\section{DIMENSÃO - COMPORTAMENTO DOS ATORES QUANTO À SUSTENTABILIDADE AMBIENTAL}

1) Indique o grau de conhecimento sobre a temática de sustentabilidade ambiental.

( ) fraco ( ) superficial ( ) razoável ( ) bom $\quad$ ( ) excelente

2) Tem interesse pelo assunto?

$\begin{array}{llll}(\text { ) nenhum } & (\text { ) pouco } & (\text { ) moderado } \quad(\text { ) elevado } \quad \text { ( ) muito }\end{array}$

3) Tem conhecimento sobre as compras públicas sustentáveis? elevado

$(\mathrm{)})$ nenhum $\quad(\mathrm{)}$ ) pouco $\quad(\mathrm{)}$ ) moderado $\quad(\mathrm{)})$ elevado

( ) muito elevado

4) Participou de quantos eventos na área de compras públicas sustentáveis ou outro com a temática da sustentabilidade ambiental, como por exemplo, o plano de logística sustentável?

$\begin{array}{lllll}\text { ( ) nenhum } & (\text { ) apenas } 1 & \text { ( ) } 2 \text { a } 3 & \text { ( ) } 3 \text { a } 4 & \text { ( ) mais de } 4\end{array}$

5) É a favor de práticas que contribuem para diminuir o impacto negativo do meio ambiente, mesmo quando consideradas mais dispendiosas.

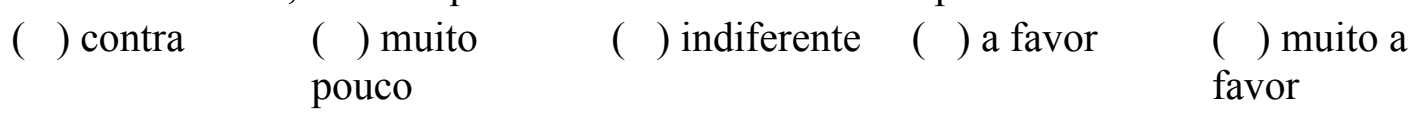

6) Indique, de acordo com seu conhecimento, algumas categorias de materiais e serviços passíveis de serem incluídos critérios sustentáveis na aquisição, dentro da sua Instituição:

7) Da maioria das categorias indicadas na questão anterior, são incluídos critérios sustentáveis nas licitações na sua Instituição?

( ) nunca ( ) raramente ( ) as vezes ( ) geralmente ( ) sempre

8) Na sua percepção, qual a maior dificuldade na sua Instituição para o êxito na execução das compras sustentáveis, de acordo com os fatores apresentados. Cite quatro mais salientes.

( ) insegurança no cumprimento da legislação

( ) indisponibilidade elevado de fornecedor

( ) resistência à mudança
( ) falta de apoio da alta administração
( ) custo ( ) comportamento ambiental dos atores

( ) falta de conscientização preparo dos ambiental servidores
( ) falta de catalogação de produtos/serviços

( ) outro 


\section{Indique o grau de concordância das referidas afirmações:}

9) As legislações relacionadas às compras públicas sustentáveis são claras e aplicáveis.

$\begin{array}{llll}\text { ( ) discordo } & (\text { ) discordo } & \begin{array}{l}(\text { ) nem } \\ \text { totalmente } \\ \text { discordo }\end{array} & (\text { ) concordo }\end{array} \quad \begin{aligned} & \text { ( ) concordo } \\ & \text { totalmente }\end{aligned}$

10) Há disponibilidade de fornecedor que atenda aos critérios de sustentabilidade quando solicitados nas licitações.
( ) discordo
( ) discordo
( ) nem
concordo nem
( ) concordo
( ) concordo
discordo
totalmente

11) Materiais e serviços sustentáveis apresentam valores superiores aos tradicionais.
( ) discordo
( ) discordo
( ) nem
( ) concordo
( ) concordo
totalmente
concordo nem
totalmente
discordo

12) Para a efetividade das compras públicas sustentáveis, o comportamento ambiental dos atores envolvidos (solicitantes, equipe gestora, compras e licitação) deve ser favorável à temática.
( ) discordo
( ) discordo
( ) nem
( ) concordo
( ) concordo
totalmente
concordo nem
totalmente
discordo

13) A catalogação dos produtos sustentáveis, contida no banco de dados CATMAT, facilita na tomada de decisão quanto à aquisição dos bens.
( ) discordo
( ) discordo
( ) nem
concordo nem
discordo
( ) concordo
( ) concordo
totalmente
totalmente

14) Uma dificuldade essencial a ser considerada na implementação das compras públicas sustentáveis é a resistência à mudança dos servidores e fornecedores.
( ) discordo
( ) discordo
( ) nem
concordo nem
( ) concordo
( ) concordo
totalmente
discordo
totalmente

15) A alta gestão da Instituição apoia as ações voltadas às compras sustentáveis.
( ) discordo
( ) discordo
( ) nem
( ) concordo
( ) concordo totalmente
concordo nem
totalmente
discordo 
16) A conscientização ambiental dos servidores frente à questão ambiental não é fator primordial na contribuição das compras públicas sustentáveis.
( ) discordo
( ) discordo
( ) nem concordo nem
( ) concordo
( ) concordo
totalmente discordo
totalmente

17) A falta de preparo dos servidores (ausência de capacitação) é um dos principais entraves ao desempenho das compras públicas sustentáveis.
( ) discordo
( ) discordo
( ) nem
( ) concordo
( ) concordo
totalmente
concordo nem
totalmente
discordo

18) A compra compartilhada é uma ferramenta eficaz no processo de aquisição que pode contribuir com as compras públicas sustentáveis.
( ) discordo
( ) discordo
( ) nem
( ) concordo
( ) concordo
concordo nem
totalmente
totalmente
discordo

19) $\mathrm{O}$ favorecimento às pequenas e microempresas, regidas pela lei 123 / 2006, contribui para fomentar o desenvolvimento regional, portanto, podendo considerar uma ferramenta para as compras públicas sustentáveis.
( ) discordo
( ) discordo
( ) nem
( ) concordo
( ) concordo concordo nem totalmente totalmente discordo

20) O critério de sustentabilidade está em consonância com o princípio da competitividade, ou seja, não fere o princípio da ampla concorrência.
( ) discordo totalmente
( ) discordo
( ) nem concordo nem
( ) concordo
( ) concordo totalmente
discordo

21) As certificações ambientais contribuem para a tomada de decisão dos gestores quanto à inserção de critérios sustentáveis nas compras públicas.
( ) discordo
( ) discordo
( ) nem concordo nem
( ) concordo totalmente discordo
( ) concordo totalmente

22) A proposta mais vantajosa inclui a promoção do desenvolvimento sustentável.
( ) discordo
( ) discordo
( ) não
( ) concordo
( ) concordo concordo nem totalmente totalmente discordo 


\section{DIMENSÃO - ROTINA ENVOLVIDA NO PROCESSO DE COMPRAS}

23) São efetuadas compras compartilhadas no IFRO?
( ) nunca
( ) raramente
( ) as vezes
( ) geralmente ( ) sempre

24) De acordo com sua experiência, as compras compartilhadas atendem às necessidades da Instituição?

( ) nunca ( ) raramente ( ) as vezes ( ) geralmente ( ) sempre

25) Problemas com a entrega são causados com maior frequência por fornecedores:
( ) Locais
( ) de
( ) de Estados
Rondônia
limítrofes
( ) da Região
( ) de Outras
regiões

26) A maior demanda de serviços do IFRO é atendida por fornecedores:
( ) Locais
( ) de
Rondônia
( ) de Estados
( ) da Região
( ) de outras
limítrofes
Norte
regiões

27) As empresas locais e regionais são priorizadas na licitação?
( ) nunca
( ) raramente
( ) as vezes
( ) geralmente ( ) sempre

28) As solicitações dos materiais a serem licitados são descritas pelos setores demandantes de forma precisa e completa?
( ) nunca
( ) raramente
( ) as vezes
( ) geralmente ( ) sempre

29) Qual setor é responsável pelo recebimento e organização das solicitações de serviços da Instituição?

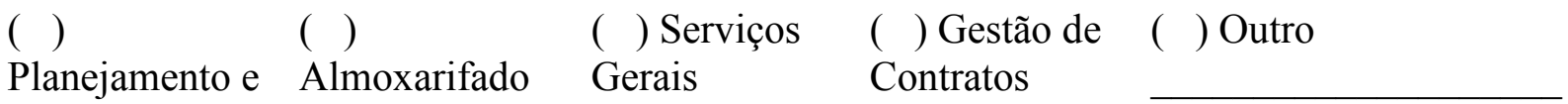
administração e Patrimônio

30) Qual setor é responsável pelo recebimento e organização das solicitações de compra de material?

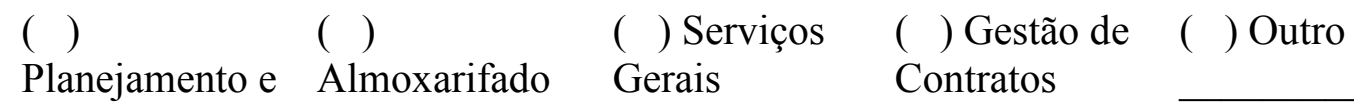
administração e Patrimônio

31) No seu ponto de vista, o que ocorre com maior frequência nas contratações de bens e serviços da Instituição?

$\begin{array}{lllll}\text { ( ) Contratar } & \text { ( ) Contratar! } & \text { ( ) Contratar } & \text { ( ) Contratar } & \text { ( ) Contratar com } \\ \text { com Menor } & \text { Independente } & \text { com menor } \\ \text { preço } & \text { de qualidade } & \begin{array}{l}\text { somente com } \\ \text { preço e com } \\ \text { qualidade }\end{array} & \begin{array}{l}\text { maior } \\ \text { qualidade }\end{array} & \begin{array}{l}\text { maior qualidade, } \\ \text { incluído critérios } \\ \text { sustentáveis }\end{array}\end{array}$


32) Quais procedimentos são adotados pelo setor de compras para adquirir produtos de melhor qualidade?

33) Qual orientação é a mais difundida na Instituição, em relação aos solicitantes, sobre os critérios a serem estabelecidos para aquisição das compras governamentais?

$\begin{array}{lllll}\text { ( ) comprar } & \text { ( ) descrever } & \text { ( ) descrever } & (\text { ) descrever } & (\text { ) descrever } \\ \text { mais barato } & \text { sem muitos } & \text { detalhadamente } & \text { detalhadamente, detalhadamente, } \\ & \text { detalhes } & & \text { sem direcionar } & \text { inserindo } \\ & & & & \end{array}$

34) Há uma integração entre os setores envolvidos nos processos de aquisições de bens e serviços, exemplo: Almoxarifado e Patrimônio com o setor de Compras ou Serviços Gerais; Setor de Compras com o Departamento de Planejamento e Administração e demais?
( ) nenhuma
( ) pouca
( ) moderada
( ) elevada
( ) muito
elevada

35) Quando as licitações não ocorrem em tempo hábil, indique até três fatores de maior destaque:

$\begin{array}{lllll}\text { ( ) Atraso na } & \text { ( ) Falhas na } & \text { ( ) Valores } & \text { ( ) Ausência } & \text { ( ) Compras } \\ \text { pesquisa de } & \text { descrição dos } & \text { acima do } & \text { de fornecedor } & \text { compartilhadas } \\ \text { preços } & \text { produtos/serviços } & \text { estimado } & \text { interessado } & \end{array}$

$\begin{array}{lllll}(\text { ) } & \text { ( ) Morosidade } & \text { ( ) Falha no } & \text { ( ) Tempo de } & \text { ( ) Outros } \\ \text { Constantes } & \text { na condução do } & \text { planejamento } & \begin{array}{l}\text { análise } \\ \text { jurídica }\end{array} & \\ \text { alterações no } & \text { processo pelo } & & \\ \text { decorrer do } & \text { órgão } & & \\ \text { processo } & \text { gerenciador } & & \end{array}$

36) Há uma fiscalização efetiva para o recebimento dos materiais adquiridos?
( ) nunca
( ) raramente
( ) as vezes
( ) geralmente ( ) sempre

37) Nas contratações de obras e serviços é priorizado o emprego da mão de obra de origem local?
( ) nunca
( ) raramente
( ) as vezes
( ) geralmente ( ) sempre

38) Há solicitação de material ou serviço com a inclusão de critérios sustentáveis nos processos licitatórios, mesmo que não seja um edital específico de compras sustentáveis?
( ) nunca
( ) raramente
( ) as vezes
( ) geralmente ( ) sempre 
39) A legislação estabelece que sejam priorizados em certas compras, fornecedores de pequena e microempresa. Em que grau é possível o cumprimento desta legislação na Instituição:
( ) muito
( ) pouco
pouco
( ) moderado
( ) elevado
( ) muito
elevado

40) São adquiridos pela Instituição materiais que tenham critérios relacionados ao menor número de embalagem em sua aquisição?
( ) nunca
( ) raramente
( ) as vezes
( ) geralmente
( ) sempre

41) Há prioridade na compra por produtos que permitam o uso de refil na Instituição?
( ) nenhuma
( ) pouca
( ) moderada
( ) elevada
( ) muito elevada

42) Que prioridade é dada à aquisição de materiais reciclados ou recicláveis nas contratações?
( ) nenhuma
( ) pouca
( ) moderada
( ) elevada
( ) muito
elevada

43) Em aquisição de gêneros alimentícios, há solicitação de alimentos orgânicos ou de agricultura familiar?
( ) nunca
( ) raramente
( ) as vezes
( ) geralmente ( ) sempre

44) Em aquisições de equipamentos permanentes, é considerado algum critério de eficiência energética, menor consumo de água ou maior durabilidade?
( ) nunca
( ) raramente
( ) as vezes
( ) geralmente
( ) sempre

\section{DIMENSÃO - CULTURA ORGANIZACIONAL SOBRE SUSTENTABILIDADE AMBIENTAL}

45) Quais das ações descritas nas opções, sua Instituição atua para estimular e incentivar as compras públicas sustentáveis? Assinale as que estiverem sendo praticadas.

( ) Há outra (s) política (s) de sustentabilidade ambiental, além das compras sustentáveis, como redução do uso de energia elétrica, água, combustível, impressões, papel, reciclagem de lixo ou conscientização quanto ao desperdício, devidamente formalizada por meio de normativas, portarias, resoluções, agendas ou outros documentos sendo desenvolvida (s) no IFRO;

( ) A Instituição mantém anualmente eventos no calendário escolar que envolvem a temática de sustentabilidade ambiental;

( ) Assuntos relacionados à sustentabilidade ambiental são disseminados regularmente entre a comunidade interna da Instituição (discentes, servidores e demais funcionários);

( ) A Instituição constantemente proporciona capacitações sobre a gestão ambiental nas organizações para os servidores, a fim de estimular os envolvidos na especificação de produtos e serviços a se incluírem critérios sustentáveis em suas solicitações;

( ) Existe e é difundido na Instituição o Plano de Logística Sustentável; 
( ) Há preocupação dos gestores em relação às aquisições e contratações de produtos e serviços que causem menor impacto negativo ao meio ambiente;

46) Há, na estrutura da Instituição, servidor ou setor responsável especificamente pelas questões ambientais? Se positivo indique a função ou cargo.

( ) $\operatorname{sim}$

( ) não

( ) desconheço

47) Caso negativo, qual o setor ou responsável que geralmente desempenha as funções relacionadas à questão ambiental na Instituição?

48) No âmbito jurídico da Instituição, há orientação clara e concisa sobre como deve ser cumprida a legislação sobre as Compras Públicas Sustentáveis?

( ) nenhuma ( ) pouca ( ) moderada ( ) elevada ( ) muito

elevada

INDIQUE O GRAU DE ACEITAÇÃO DAS COMPRAS SUSTENTÁVEIS NO PONTO DE VISTA PESSOAL

( ) nenhuma ( ) pouca ( ) moderada ( ) elevada $\quad \begin{gathered}\text { ( ) muito } \\ \text { elevada }\end{gathered}$

DE ACORDO COM SUA PERCEPÇÃO INDIQUE O GRAU DE ACEITAÇÃO DAS COMPRAS SUSTENTÁVEIS PELA INSTITUIÇÃO
( ) nenhuma
( ) pouca
( ) moderada
( ) elevada
( ) muito
elevada

Agradeço a atenção dispensada no preenchimento do questionário, sua contribuição foi de extrema importância no desenvolvimento desta pesquisa. 


\section{APÊNDICE C - FORMAÇÃO, CARGO E EXIGÊNCIA DA TITULAÇÃO DE NÍVEL INTERMEDIÁRIO (NI) PARA O CARGO}

\begin{tabular}{|c|c|c|}
\hline Formação & Cargo/Função & $\begin{array}{c}\text { Titulação superior } \\
\text { a exigida para o } \\
\text { cargo de Nível } \\
\text { Médio }\end{array}$ \\
\hline Ciências contábeis & Contador & Não se aplica \\
\hline Ciências contábeis & Contador & Não se aplica \\
\hline Ciências contábeis & Técnico em Contabilidade & Sim \\
\hline Ciências contábeis & $\begin{array}{l}\text { Sem informação do cargo /Diretora de } \\
\text { Administração }\end{array}$ & $\begin{array}{l}\text { Faltou informação } \\
\text { do cargo }\end{array}$ \\
\hline Ciências contábeis e Direito & Assistente em Administração/Auditora Interna & Sim \\
\hline Ciências Contábeis e Matemática & $\begin{array}{l}\text { Contador/Pró-Reitor de Planejamento e } \\
\text { Administração }\end{array}$ & Não se aplica \\
\hline Ciências Contábeis & Assistente em Administração/Coord. Serviços Gerais & Sim \\
\hline Ciências Contábeis & Assistente em Administração & Sim \\
\hline Ciências Contábeis & Sem informação do cargo e da função & $\begin{array}{l}\text { Sem informação do } \\
\text { cargo }\end{array}$ \\
\hline Ciências Contábeis & Técnico em Contabilidade & Sim \\
\hline Ciências Contábeis & Sem informação do cargo e da função & $\begin{array}{l}\text { Sem informação do } \\
\text { cargo }\end{array}$ \\
\hline Ciências Contábeis & Sem informação do cargo e da função & $\begin{array}{l}\text { Sem informação do } \\
\text { cargo }\end{array}$ \\
\hline Ciências Contábeis & $\begin{array}{l}\text { Assistente em Administração/Coord. Orçamento e } \\
\text { Finanças }\end{array}$ & Sim \\
\hline Ciências Contábeis & Contadora & Não se aplica \\
\hline Ciências Contábeis & Auxiliar Rural & Sim \\
\hline Ciências Contábeis & Assistente em Administração & Sim \\
\hline Ciências Contábeis & Assistente em Administração & Sim \\
\hline Administração & $\begin{array}{l}\text { Administradora/Chefe Setor de Contratos e } \\
\text { Convênios }\end{array}$ & Não se aplica \\
\hline Administração & Sem informação do cargo e da função & $\begin{array}{l}\text { Sem informação do } \\
\text { cargo }\end{array}$ \\
\hline Administração & administradora/Coord. Patrimoniônio e Almox. & Não se aplica \\
\hline Tecnólogo em Gestão Pública & Assistente em Administração/COFIN & Sim \\
\hline Gestão Pública & Assistente em Administração & Sim \\
\hline Administração & Administrador & Não se aplica \\
\hline $\begin{array}{l}\text { Administração/Administração } \\
\text { Pública }\end{array}$ & Administrador & Não se aplica \\
\hline Administração & Assistente em Administração & Sim \\
\hline Administração & $\begin{array}{l}\text { Administrador/Diretora de Planejamento e } \\
\text { Orçamento }\end{array}$ & Não se aplica \\
\hline Administração & Administrador & Não se aplica \\
\hline Gestão Pública & $\begin{array}{l}\text { Sem informação do cargo /Coord. De compras e } \\
\text { licitação }\end{array}$ & $\begin{array}{l}\text { Sem informação do } \\
\text { cargo }\end{array}$ \\
\hline
\end{tabular}




\begin{tabular}{|c|c|c|}
\hline Administração & $\begin{array}{l}\text { Recepcionista/Diretora de Planejamento e } \\
\text { Administração }\end{array}$ & Sim \\
\hline Gestão Pública & $\begin{array}{l}\text { Assistente em Administração/Coord. Orçamento e } \\
\text { Finanças }\end{array}$ & Sim \\
\hline Administração & Professor EBTT/DPLAD & Não se aplica \\
\hline Administração & $\begin{array}{l}\text { Assistente em Administração/Coord. De Compras e } \\
\text { Licitação }\end{array}$ & Sim \\
\hline Administração & Sem informação do cargo /Chefe de Gabinete & $\begin{array}{l}\text { Sem informação do } \\
\text { cargo }\end{array}$ \\
\hline Tecnologia em Gestão Pública & Tecnólogo em Gestão Pública & Não se aplica \\
\hline Administração Pública & $\begin{array}{l}\text { Assistente em Administração/Diretor de } \\
\text { Planejamento e Administração }\end{array}$ & Sim \\
\hline Administração & Administrador & Não se aplica \\
\hline Tecnologia em Gestão Pública & $\begin{array}{l}\text { Assistente em Administração/Coord. Orçamento e } \\
\text { Finanças }\end{array}$ & Sim \\
\hline Administração & Sem informação do cargo /Pregoeiro & $\begin{array}{l}\text { Sem informação do } \\
\text { cargo }\end{array}$ \\
\hline Administração & Sem informação do cargo /Diretor-Geral & $\begin{array}{l}\text { Sem informação do } \\
\text { cargo }\end{array}$ \\
\hline Ensino médio & $\begin{array}{l}\text { Sem informação do cargo /Coord. De compras e } \\
\text { licitação }\end{array}$ & $\begin{array}{l}\text { Sem informação do } \\
\text { cargo }\end{array}$ \\
\hline Informática & Docente EBTT/Diretor Geral & Não se aplica \\
\hline Ensino médio & Sem informação do cargo e da função & Não se aplica \\
\hline Sem informação & Assistente em Administração & $\begin{array}{l}\text { Sem informação da } \\
\text { titulação }\end{array}$ \\
\hline Direito & $\begin{array}{l}\text { Assistente em Administração/Coordenação de } \\
\text { Compras }\end{array}$ & Sim \\
\hline Sem informação & Assistente em Administração & $\begin{array}{l}\text { Sem informação da } \\
\text { titulação }\end{array}$ \\
\hline Sem informação & Assistente em Administração & $\begin{array}{l}\text { Sem informação da } \\
\text { titulação }\end{array}$ \\
\hline Processamento de dados & $\begin{array}{l}\text { Professor/Pró-Reitor de Desenvolvimento } \\
\text { Institucional }\end{array}$ & Não se aplica \\
\hline Sem informação & Docente EBTT/Assessor do Reitor & $\begin{array}{l}\text { Sem informação da } \\
\text { titulação }\end{array}$ \\
\hline Engenheiro Civil & Sem informação do cargo /Diretor de Engenharia & $\begin{array}{l}\text { Sem informação do } \\
\text { cargo }\end{array}$ \\
\hline Bacharel em Enfermagem & Sem informação do cargo e da função & $\begin{array}{l}\text { Sem informação do } \\
\text { cargo }\end{array}$ \\
\hline Sem informação & $\begin{array}{l}\text { Sem informação do cargo /Coordenador de } \\
\text { Orçamento e Finanças }\end{array}$ & $\begin{array}{l}\text { Sem informação do } \\
\text { cargo e da titulação }\end{array}$ \\
\hline Sem informação & $\begin{array}{l}\text { Assistente em Administração/Coord. Contratos e } \\
\text { Convênios }\end{array}$ & $\begin{array}{l}\text { Sem informação da } \\
\text { titulação }\end{array}$ \\
\hline Engenharia Agronômica & Assistente em Administração & Sim \\
\hline Arquiteto e Urbanista & Professor/Diretor Geral & Não se aplica \\
\hline Técnico em Edificações & Sem informação do cargo e da função & $\begin{array}{l}\text { Sem informação do } \\
\text { cargo }\end{array}$ \\
\hline Sem informação & Sem informação do cargo /Coord. CPALM & $\begin{array}{l}\text { Sem informação do } \\
\text { cargo e da titulação }\end{array}$ \\
\hline $\begin{array}{l}\text { Pedagogia/Técn. Logística; Técn. } \\
\text { Secretaria Escolar }\end{array}$ & Técnico em Secretariado & Sim \\
\hline Ciência da Computação & Assistente em Administração & Sim \\
\hline Sem informação & Assistente em Administração & $\begin{array}{l}\text { Sem informação da } \\
\text { titulação }\end{array}$ \\
\hline
\end{tabular}




\begin{tabular}{|c|c|c|}
\hline Tecnólogo em Produção Industrial & Sem informação do cargo /Coord. Serviços Gerais & $\begin{array}{l}\text { Sem informação do } \\
\text { cargo }\end{array}$ \\
\hline Economia & $\begin{array}{l}\text { Sem informação do cargo /Coordenador de } \\
\text { Patrimônio e Almoxarifado }\end{array}$ & $\begin{array}{l}\text { Sem informação do } \\
\text { cargo }\end{array}$ \\
\hline $\begin{array}{l}\text { Tecnólogo em Desenvolvimento } \\
\text { de Sistemas da Informação }\end{array}$ & $\begin{array}{l}\text { Sem informação do cargo /Coordenador de } \\
\text { Serviços Gerais }\end{array}$ & $\begin{array}{l}\text { Sem informação do } \\
\text { cargo }\end{array}$ \\
\hline Técnico em Edificações & Sem informação do cargo & $\begin{array}{l}\text { Sem informação do } \\
\text { cargo }\end{array}$ \\
\hline Sem informação & $\begin{array}{l}\text { Assistente em Administração/Coord. De Serviços } \\
\text { Gerais }\end{array}$ & $\begin{array}{l}\text { Sem informação da } \\
\text { titulação }\end{array}$ \\
\hline Sem informação & Assistente em Administração/ & $\begin{array}{l}\text { Sem informação da } \\
\text { titulação }\end{array}$ \\
\hline Inspeção Escolar & $\begin{array}{l}\text { Técnica em Assuntos Educacionais/ Diretora Geral } \\
\text { Substituta }\end{array}$ & Não se aplica \\
\hline Medicina Veterinária & Professor EBTT/Diretora-Geral & Não se aplica \\
\hline Tecnólogo em Gestão Ambiental & $\begin{array}{l}\text { Professor EBTT/Diretor do Departamento de } \\
\text { Produção }\end{array}$ & Não se aplica \\
\hline Nutrição & Nutricionista/Coord. De Alimentação e Nutrição & Não se aplica \\
\hline Eletricista & Eletricista/Coord. Compras e Licitação & Não \\
\hline Agronomia & $\begin{array}{l}\text { Sem informação do cargo /Diretor do } \\
\text { Departamento de Assistência ao Educando }\end{array}$ & $\begin{array}{l}\text { Sem informação do } \\
\text { cargo }\end{array}$ \\
\hline Técnico em Agropecuária & Técnico em Agropecuária/ & Não \\
\hline Técnico em Agropecuária & $\begin{array}{l}\text { Assistente em Administração/Coord. De Gestão de } \\
\text { Contratos }\end{array}$ & Não \\
\hline Direito & Assistente em Administração & Sim \\
\hline Jornalismo & Assistente em Administração & Sim \\
\hline Pedagogia e Física & Professor/Diretor Geral & Não se aplica \\
\hline Lic. Plena em História & Assistente em Administração/Fiscal de Contratos & Sim \\
\hline História & $\begin{array}{l}\text { Sem informação do cargo /Pesquisador } \\
\text { Institucional }\end{array}$ & $\begin{array}{l}\text { Sem informação do } \\
\text { cargo }\end{array}$ \\
\hline Ciências Biológicas/Direito & Assistente em Administração & Sim \\
\hline Licenciatura em Matemática & $\begin{array}{l}\text { Assistente em Administração/Coord. De Compras e } \\
\text { Licitação }\end{array}$ & Sim \\
\hline Letras & $\begin{array}{l}\text { Assistente em Administração/Diretora de } \\
\text { Planejamento e Administração }\end{array}$ & Sim \\
\hline Licenciatura em Química & Sem informação do cargo & $\begin{array}{l}\text { Sem informação do } \\
\text { cargo }\end{array}$ \\
\hline $\begin{array}{l}\text { Licenciatura Plena em Ciências } \\
\text { Agrícolas }\end{array}$ & Professor EBTT & Não se aplica \\
\hline
\end{tabular}




\section{APÊNDICE D - AÇÕES PRATICADAS PELA INSTITUIÇÃO QUE FOMENTAM ÀS CPS, POR UNIDADE DE LOTAÇÃO DOS RESPONDENTES}

\begin{tabular}{|c|c|c|c|c|}
\hline \multicolumn{5}{|c|}{ Ações praticadas pela Instituição que fomentam às CPS, por unidade de lotação dos respondentes. } \\
\hline \multirow{2}{*}{\multicolumn{3}{|c|}{ Campus de lotação }} & \multicolumn{2}{|c|}{ Respostas } \\
\hline & & & $\mathrm{N}$ & Percentual \\
\hline \multirow[t]{6}{*}{ Reitoria } & \multirow{5}{*}{$\begin{array}{l}\text { Ações praticadas que } \\
\text { estimulam as } \mathrm{CPS}^{\text {a }}\end{array}$} & Há outra política, devidamente formalizada & 11 & $40,7 \%$ \\
\hline & & Mantém anualmente eventos & 6 & $22,2 \%$ \\
\hline & & $\begin{array}{l}\text { São disseminados assuntos de sustentabilidade } \\
\text { ambiental regularmente }\end{array}$ & 3 & $11,1 \%$ \\
\hline & & $\begin{array}{l}\text { Existe e é difundido o Plano de Logística } \\
\text { Sustentável }\end{array}$ & 1 & $3,7 \%$ \\
\hline & & Há preocupação pelos gestores ref. às CPS & 6 & $22,2 \%$ \\
\hline & \multicolumn{2}{|r|}{ 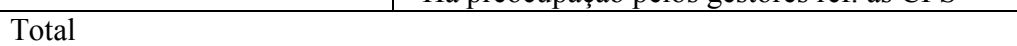 } & 27 & $100,0 \%$ \\
\hline \multirow[t]{5}{*}{ Calama } & \multirow{4}{*}{$\begin{array}{l}\text { Ações praticadas que } \\
\text { estimulam as } \text { CPS }^{\mathrm{a}}\end{array}$} & Há outra política, devidamente formalizada & 8 & $34,8 \%$ \\
\hline & & Mantém anualmente eventos & 4 & $17,4 \%$ \\
\hline & & $\begin{array}{l}\text { São disseminados assuntos de sust. ambiental } \\
\text { regularmente }\end{array}$ & 5 & $21,7 \%$ \\
\hline & & Há preocupação pelos gestores ref. às CPS & 6 & $26,1 \%$ \\
\hline & \multicolumn{2}{|r|}{ 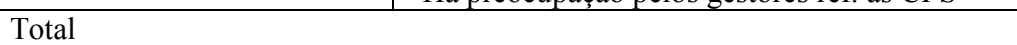 } & 23 & $100,0 \%$ \\
\hline \multirow[t]{4}{*}{ Zona Norte } & \multirow{3}{*}{$\begin{array}{l}\text { Ações praticadas que } \\
\text { estimulam as CPS }\end{array}$} & Há outra política, devidamente formalizada & 3 & $42,9 \%$ \\
\hline & & Mantém anualmente eventos & 3 & $42,9 \%$ \\
\hline & & Há preocupação pelos gestores ref. às CPS & 1 & $14,3 \%$ \\
\hline & \multicolumn{2}{|r|}{ 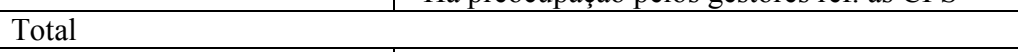 } & 7 & $100,0 \%$ \\
\hline \multirow[t]{5}{*}{ Ariquemes } & \multirow{4}{*}{$\begin{array}{l}\text { Ações praticadas que } \\
\text { estimulam as } \text { CPS }^{\mathrm{a}}\end{array}$} & Há outra política, devidamente formalizada & 3 & $27,3 \%$ \\
\hline & & Mantém anualmente eventos & 3 & $27,3 \%$ \\
\hline & & $\begin{array}{l}\text { São disseminados assuntos de sust. ambiental } \\
\text { regularmente }\end{array}$ & 1 & $9,1 \%$ \\
\hline & & Há preocupação pelos gestores ref. às CPS & 4 & $36,4 \%$ \\
\hline & \multicolumn{2}{|r|}{ 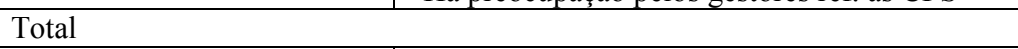 } & 11 & $100,0 \%$ \\
\hline \multirow[t]{5}{*}{ JIPA } & \multirow{4}{*}{$\begin{array}{l}\text { Ações praticadas que } \\
\text { estimulam as } \text { CPS }^{\mathrm{a}}\end{array}$} & Há outra política, devidamente formalizada & 2 & $33,3 \%$ \\
\hline & & Mantém anualmente eventos & 1 & $16,7 \%$ \\
\hline & & $\begin{array}{l}\text { São disseminados assuntos de sust. ambiental } \\
\text { regularmente }\end{array}$ & 1 & $16,7 \%$ \\
\hline & & Há preocupação pelos gestores ref. às CPS & 2 & $33,3 \%$ \\
\hline & \multicolumn{2}{|r|}{ 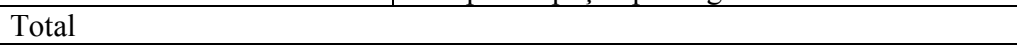 } & 6 & $100,0 \%$ \\
\hline \multirow[t]{5}{*}{ Cacoal } & \multirow{4}{*}{$\begin{array}{l}\text { Ações praticadas que } \\
\text { estimulam as } \mathrm{CPS}^{\mathrm{a}}\end{array}$} & Há outra política, devidamente formalizada & 3 & $37,5 \%$ \\
\hline & & Mantém anualmente eventos & 2 & $25,0 \%$ \\
\hline & & $\begin{array}{l}\text { São disseminados assuntos de sust. ambiental } \\
\text { regularmente }\end{array}$ & 2 & $25,0 \%$ \\
\hline & & Há preocupação pelos gestores ref. às CPS & 1 & $12,5 \%$ \\
\hline & \multicolumn{2}{|l|}{ Total } & 8 & $100,0 \%$ \\
\hline \multirow[t]{4}{*}{ Vilhena } & \multirow{3}{*}{$\begin{array}{l}\text { Ações praticadas que } \\
\text { estimulam as } \text { CPS }^{\mathrm{a}}\end{array}$} & Mantém anualmente eventos & 4 & $57,1 \%$ \\
\hline & & $\begin{array}{l}\text { São disseminados assuntos de sust. ambiental } \\
\text { regularmente }\end{array}$ & 2 & $28,6 \%$ \\
\hline & & Há preocupação pelos gestores ref. às CPS & 1 & $14,3 \%$ \\
\hline & \multicolumn{2}{|l|}{ Total } & 7 & $100,0 \%$ \\
\hline \multirow{5}{*}{$\begin{array}{l}\text { Colorado do } \\
\text { Oeste }\end{array}$} & \multirow{4}{*}{$\begin{array}{l}\text { Ações praticadas que } \\
\text { estimulam as } \mathrm{CPS}^{\mathrm{a}}\end{array}$} & Há outra política, devidamente formalizada & 5 & $20,8 \%$ \\
\hline & & Mantém anualmente eventos & 12 & $50,0 \%$ \\
\hline & & $\begin{array}{l}\text { São disseminados assuntos de sust. ambiental } \\
\text { regularmente }\end{array}$ & 2 & $8,3 \%$ \\
\hline & & Há preocupação pelos gestores ref. às CPS & 5 & $20,8 \%$ \\
\hline & Total & & 24 & $100,0 \%$ \\
\hline
\end{tabular}




\section{APÊNDICE E - TESTE ESTATÍSTICO U DE MANN WHITNEY}

\begin{tabular}{|c|c|c|c|}
\hline \multicolumn{4}{|l|}{ Teste estatístico U de Mann Whitney } \\
\hline & $\begin{array}{l}\text { Ude Mann- } \\
\text { Whitney }\end{array}$ & Z & $\begin{array}{l}\text { Asymp. Sig. } \\
\text { (2-tailed) }\end{array}$ \\
\hline As empresas locais e regionais são priorizadas na licitação? & 569,000 &,- 928 &, 353 \\
\hline $\begin{array}{l}\text { As solicitações dos materiais a serem licitados são descritas pelos setores } \\
\text { demandantes de forma precisa e correta? }\end{array}$ & 706,500 &,- 227 & ,821 \\
\hline Há uma interação entre os setores envolvidos nos processos de compras e serviços? & 739,500 &,- 452 & 652 \\
\hline Há uma fiscalização efetiva para o recebimento dos materiais adquiridos? & 698,000 &,- 915 & ,360 \\
\hline $\begin{array}{l}\text { Nas contratações de obras e serviços é priorizado o emprego de mão de obra de } \\
\text { origem local? }\end{array}$ & 503,000 &,- 901 & ,368 \\
\hline $\begin{array}{l}\text { Há solicitação de material ou serviço com a inclusão de critérios sustentáveis nos } \\
\text { processos licitatórios, mesmo que não seja um edital específico de CPS? }\end{array}$ & 497,000 & 1,722 & , 085 \\
\hline $\begin{array}{l}\text { A legislação estabelece que sejam priorizados em certas compras, fornecedores de } \\
\text { pequena e microempresa, em que grau é possível? }\end{array}$ & 566,000 &,- 820 & ,412 \\
\hline $\begin{array}{l}\text { São adquiridos pela Instituição materiais que tenham critérios relacionados ao } \\
\text { menor número de embalagens em sua aquisição? }\end{array}$ & 492,000 & 1,573 & , 116 \\
\hline Há prioridade na compra por produtos que permitam o uso de refil na Instituição? & 588,500 &,- 259 & ,795 \\
\hline $\begin{array}{l}\text { Que prioridade é dada à aquisição de materiais reciclados ou recicláveis nas } \\
\text { contratações? }\end{array}$ & 612,500 &,- 437 & ,662 \\
\hline $\begin{array}{l}\text { Em aquisição de gêneros alimentícios, há solicitação de alimentos orgânicos ou de } \\
\text { agricultura familiar? }\end{array}$ & 370,000 & $2,387^{-}$ & ,017 \\
\hline $\begin{array}{l}\text { Em aquisições de equipamentos permanentes, é considerado algum critério de } \\
\text { eficiência energética, menor consumo de água ou maior durabilidade? }\end{array}$ & 637,000 &,- 261 & ,794 \\
\hline
\end{tabular}

Nota: Grupo de variáveis Reitoria e Campus

\section{APÊNDICE F - GRÁFICO SCREE PLOT DA ANÁLISE FATORIAL}

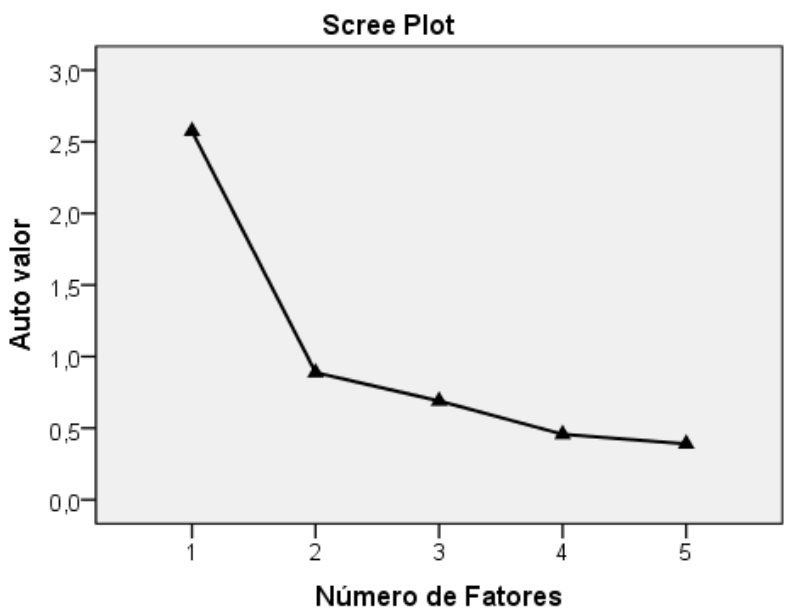

